\title{
BTD Building Uranium Mass Balance Study
}
S. L. Sutter
J. W. Johnston
J. A. Glissmeyer
G. F. Athey

January 1985

Prepared for

the U.S. Army

under a Related Services Agreement

with the U.S. Department of Energy

under Contract DE-AC06-76RLO 1830

Pacific Northwest Laboratory

Operated for the U.S. Department of Energy

by Battelle Memorial Insitute 


\title{
DISCLAIMER
}

This report was prepared as an account of work sponsored by an agency of the United States Government. Neither the United States Government nor any agency thereof, nor any of their employees, makes any warranty, express or implied, or assumes any legal liability or responsibility for the accuracy, completeness, or usefulness of any information, apparatus, product, or process disclosed, or represents that its use would not infringe privately owned rights. Reference herein to any specific commercial product, process, or service by trade name, trademark, manufacturer, or otherwise, does not necessarily constitute or imply its endorsement, recommendation, or favoring by the United States Government or any agency thereof. The views and opinions of authors expressed herein do not necessarily state or reflect those of the United States Government or any agency thereof.

\author{
PACIFIC NORTHWEST LABORATORY \\ operated by \\ BATTELLE \\ for the \\ UNITED STATES DEPARTMENT OF ENERGY \\ under Contract DE-AC06-76RLO 1830
}

\begin{tabular}{|c|c|}
\hline \multicolumn{2}{|c|}{$\begin{array}{c}\text { Printed in the United States of America } \\
\text { Available from } \\
\text { National Technical Information Service } \\
\text { United States Department of Commerce } \\
5285 \text { Port Royal Road } \\
\text { Springfield, Virginia } 22161\end{array}$} \\
\hline \multicolumn{2}{|c|}{$\begin{array}{l}\text { NTIS Price Codes } \\
\text { Microfiche A01 }\end{array}$} \\
\hline \multicolumn{2}{|c|}{ Printed Copy } \\
\hline Pages & $\begin{array}{l}\text { Price } \\
\text { Codes }\end{array}$ \\
\hline 001-025 & $\mathrm{A} 02$ \\
\hline $026-050$ & $\mathrm{~A} 03$ \\
\hline 051-075 & A04 \\
\hline $076-100$ & A05 \\
\hline $101-125$ & A06 \\
\hline $126-150$ & A07 \\
\hline $151-175$ & $A 0 B$ \\
\hline $176-200$ & A09 \\
\hline $201-225$ & A010 \\
\hline $226-250$ & A011 \\
\hline $251-275$ & A012 \\
\hline $276-300$ & A013 \\
\hline
\end{tabular}




\section{1}

BTD BUILDING URANIUM MASS BALANCE STUDY

S. L. Sutter

J. W. Johnston

J. A. Gi issmeyer

G. F. Athey

January 1985

Prepared for the U.S. Army under a Related Services Agreement with the U.S. Department of Energy under Contract DE-AC06-76RL0 1830

Pacific Northwest Laboratory

Richland, Washington 99352 
-

a

$n$ 


\section{SUMMARY}

Fifteen test firings of depleted uranium (DU) munitions were made during the qualification study of the new target butlding at the BTD Range operated by the U.S. Army Combat Systems Test Activity (CSTA) at Aberdeen Proving Ground, Maryland. Following these test firings, Pacific Northwest Laboratory determined the total mass and mass distribution of DU inside the BTD facility to define decontamination requirements for the new target building.

The 15 rounds fired were grouped into 5 runs of 3 rounds each for this mass balance investigation. Three forms of DU were sampled after the runs: nonaerosol particles, aerosol particles depositing onto interior surfaces, and aerosol particles depositing in the filters.

Most of the results could logically be anticipated:

1. Depleted uranium tray samples from the floor represented the largest portion of the uranium collected.

2. The target backstop samples accounted for about twice as much DU as the equipment surfaces.

3. The weighted average of the building surface deposition was greatest for the back wall and lowest for the ceiling.

4. Aerosols showed a tendency for increased deposition from the building front to back.

5. The amount of Du collected by the filters declined progressively with each successive filter stage.

The estimated random error standard deviation (precision) for the DU quantity in an area was $6 \%$ to $15 \%$ relative; systematic error (accuracy) was $5 \%$ to $12 \%$ relative. 
ก

a

-

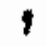




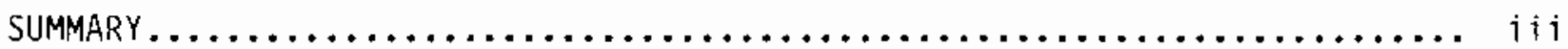

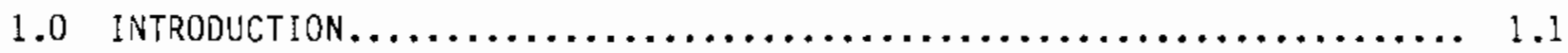

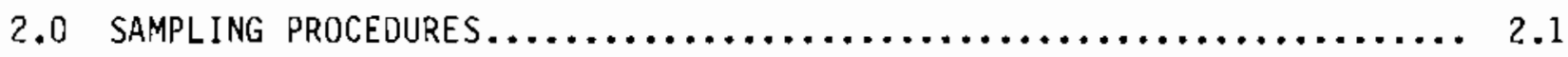

2.1 SAMPLE COLLECTION............................... 2.1

2.1.1 Floor Tray and Scoop and Sweep Samples.............. 2.1

2.1 .2 Coupon Samples............................ 2.3

2.1 .3 Filter Samples............................ 2.3

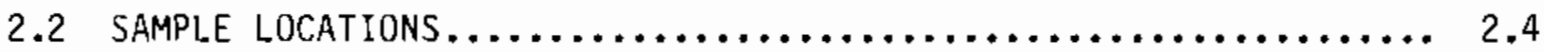

2.2.1 Floor Tray and Scoop and Sweep Samples............ 2.5

2.2 .2 Coupon Samples........................... 2.5

2.2 .3 Filter Samples...................................

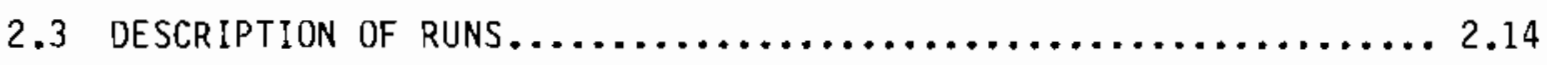

2.4 QUALITY CONTROL FOR LEACHING AND ANALYTICAL MEASUREMENTS $\ldots \ldots \ldots 2.18$

2.4 .1 yield Standards.............................. 2.18

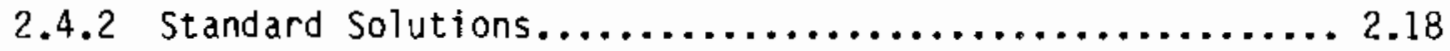

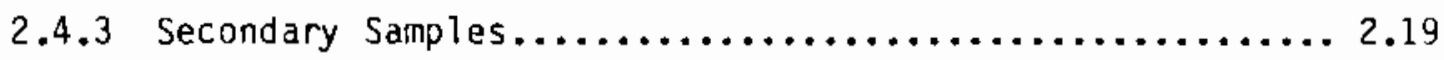

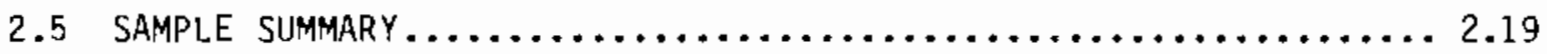

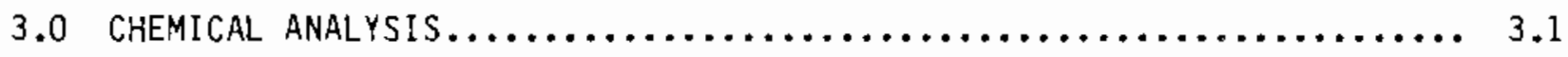

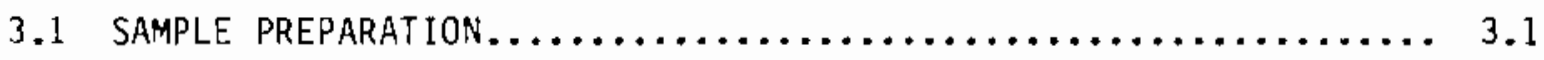

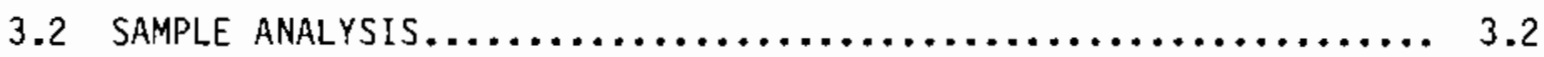

3.2.1 Kinetic Laser Fluorometry................... 3.2

3.2.2 Ferrous Sulfate-Potassium Dichromate Titrimetry........ 3.3

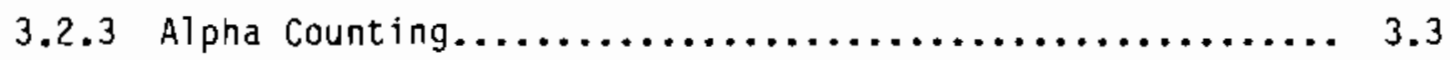


4.0 DATA ANALYSES $\ldots \ldots \ldots \ldots \ldots \ldots \ldots \ldots \ldots \ldots \ldots \ldots \ldots \ldots \ldots \ldots \ldots \ldots \ldots \ldots \ldots \ldots \ldots, 4.1$

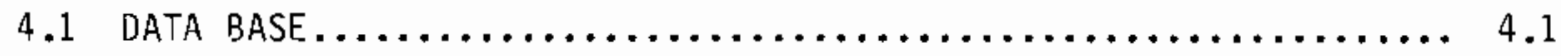

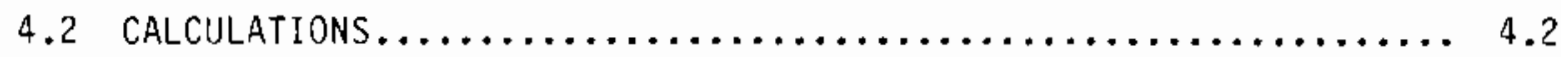

4.2 .1 Total Uranium.................................. 4.2

4.2.2 Uranium Per Square Foot........................ 4.3

4.3 SUMMARY OF RESULTS $\ldots \ldots \ldots \ldots \ldots \ldots \ldots \ldots \ldots \ldots \ldots \ldots \ldots \ldots \ldots \ldots \ldots \ldots \ldots \ldots, 4$

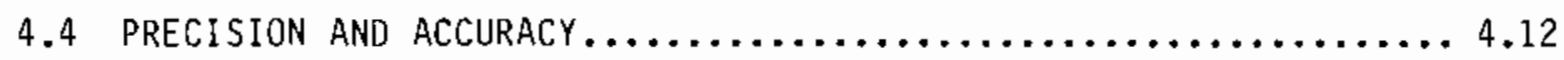

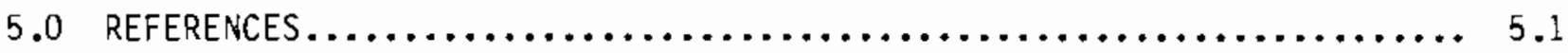

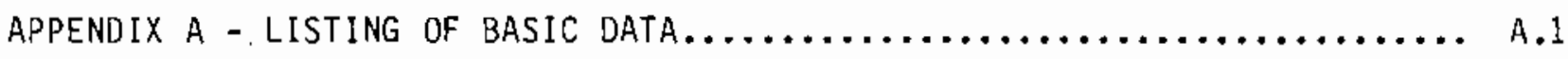

APPENDIX B - LISTING OF STANDARD SOLUTION AND YIELD STANDARD RESULTS...... B. 1 


\section{FIGURES}

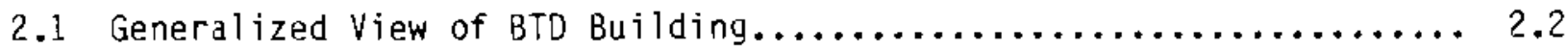

2.2 Typical Filter Samples, Two Folds...................... 2.4

2.3 Exploded View of Enclosure Sampling Areas.................. 2.6

2.4 Filter House Sampling Areas.......................... 2.7

2.5 BTD Floor Sampling Areas............................ 2.9

2.6 Target Table Surfaces.............................. 2.10

2.7 Overhead $x$-ray Table Surfaces.......................... 2.10

2.8 Coordinates for the Film Frame and Film Frame Shield From Door

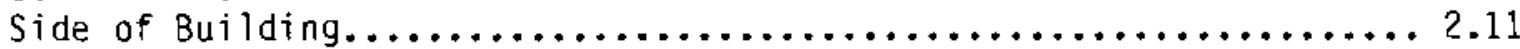

2.9 Side and Front View of Backstop Primary and Secondary Plates...... 2.11

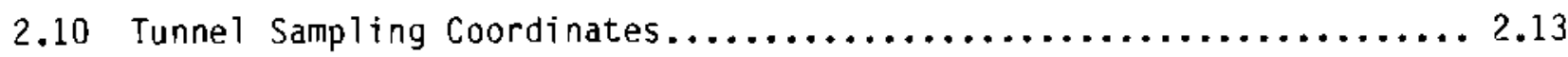

2.11 General View of Plenum...................................

2.12 Sampling Coordinates for Plenum Floor, Ceiling, and Walls....... 2.15

2.13 Plenum Baffle Sampling Coordinates..................... 2.16

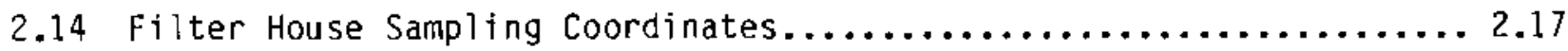

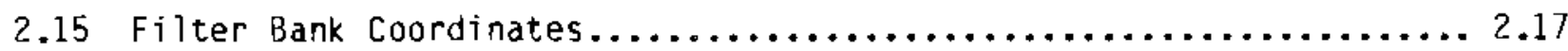

4.1 Percentage of OU Accounted For $\ldots \ldots \ldots \ldots \ldots \ldots \ldots \ldots \ldots \ldots \ldots \ldots \ldots$

4.2 Aggregation of Sampling Locations for Summaries, Grams/ft ${ }^{2} /$ Round.... 4.11 


\section{$\underline{\text { TABLES }}$}

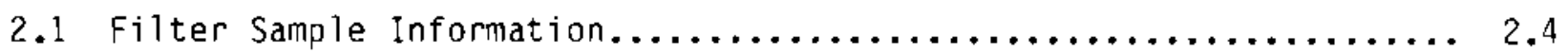

2.2 Enclosure Areas Represented by Tray and Coupon Samples.......... 2.8

4.1 Number of Samples and Analyses........................ 4.2

4.2 Aggregation of Sampling Locations for Sumnaries.............. 4.4

4.3 Total Depleted Uranium Accounted For $\ldots \ldots \ldots \ldots \ldots \ldots \ldots \ldots \ldots \ldots \ldots$

4.4 Percentage of Projectile Weight Accounted For............... 4.7

4.5 Test Conditions................................. 4.7

4.6 Summary for Areas and Subareas....................... 4.8

4.7 Total and Weighted-Average DU Wall Deposition and Ranking........ 4.9

4.8 Total Grams DU and Grams $/ \mathrm{ft}^{2} /$ Round for Each Location............ 4.10

4.9 Measurement Uncertainties........................... 4.13

A.1 Coding for BTD Mass Balance Data Files..................... A.1

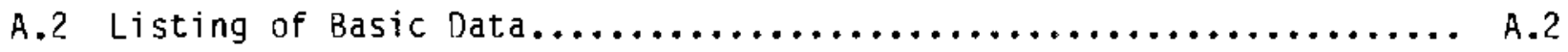

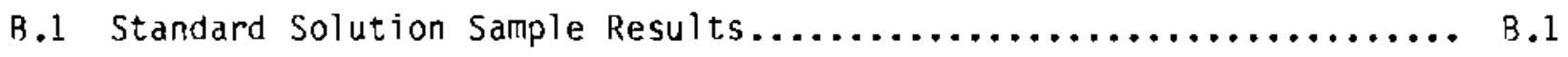

B.2 Coupon Yield Standard Sample Results..................... B.2

B.3 Filter Yield Standard Sample Results....................... B.3

B.4 Soil Yield Standard Sample Results...................... B.4 


\subsection{INTROOUCTION}

The U.S. Army Combat Systems Test Activity (CSTA) constructed a new target building at its BTD range in the Aberdeen Proving Ground, Maryland, for the test firing of depleted uranium (DU) munitions. The objective of this study, which was conducted by Pacific Northwest Laboratory (PNL), was to determine the total mass and mass distribution of uranium inside the target building following test firings of DU penetrators. This information will be useful in defining the BTD range decontamination requirements.

Fifteen test firings (rounds) of DU munitions were made in the building during a qualification study. To determine the uranium mass, these rounds were grouped into 5 runs of 3 rounds each and samples collected after each run. A background run was made before the rounds were fired to determine whether significant levels of material that would interfere with the uranium analysis were present. This report details this sampling (Sections 2 and 3 ) and presents the results of the data analysis (Section 4). Basic data for the analysis are in Appendix $A$. Results for standard solutions and yield standards submitted for quality control of leaching and analytical methods are in Appendix B. 


\subsection{SAMPLING PROCEDURES}

Appropriate sampling methods were developed to sample OU in various areas of the BTD facility. A schematic view of this building is shown in Figure 2.1. It has three major components: the target bay or building interior, the baffled plenum, and the filter house. The front of the building is the end where the projectile enters the building through the tunnel; the back is the end where air is exhausted from the target bay.

This section describes the sample collection methods and then defines the stratification of the facility into areas (locations) for sampling. This is followed by a description of the runs, shots within the runs, and quality control samples and standards.

\subsection{SAMPLE COLLECTION}

Three DU forms must be accounted for after each run:

- nonaerosol particles, consisting of pieces of projectiles and piles of oxidized DU

- aerosol particles depositing onto interior surfaces

- aerosol particles depositing in the filters

Different sampling techniques were used for each form. Nonaerosol particles were recovered by picking up DU chunks, scooping up piles of oxidized DU, or sweeping up large quantities of oxidized DU dust. Visible piles of DU were swept or scooped from equipment surfaces. Aerosol particles depositing on floor, ceiling, wall, and equipment surfaces were sampled by devices that simulated those surfaces and covered a limited portion of the total surface area. These devices were gravel-filled trays implanted in the gravel floor and steel coupons fastened to steel surfaces. The ventilation system air filters were sampled by cutting representative portions of the filter media from the filters for analysis.

\subsubsection{Floor Tray and Scoop and Sweep Samples}

Plastic trays containing gravel were embedded in the gravel floor at random locations. These samplers had dimensions of $4.75 \mathrm{in}$. by $3.75 \mathrm{in}$. by 


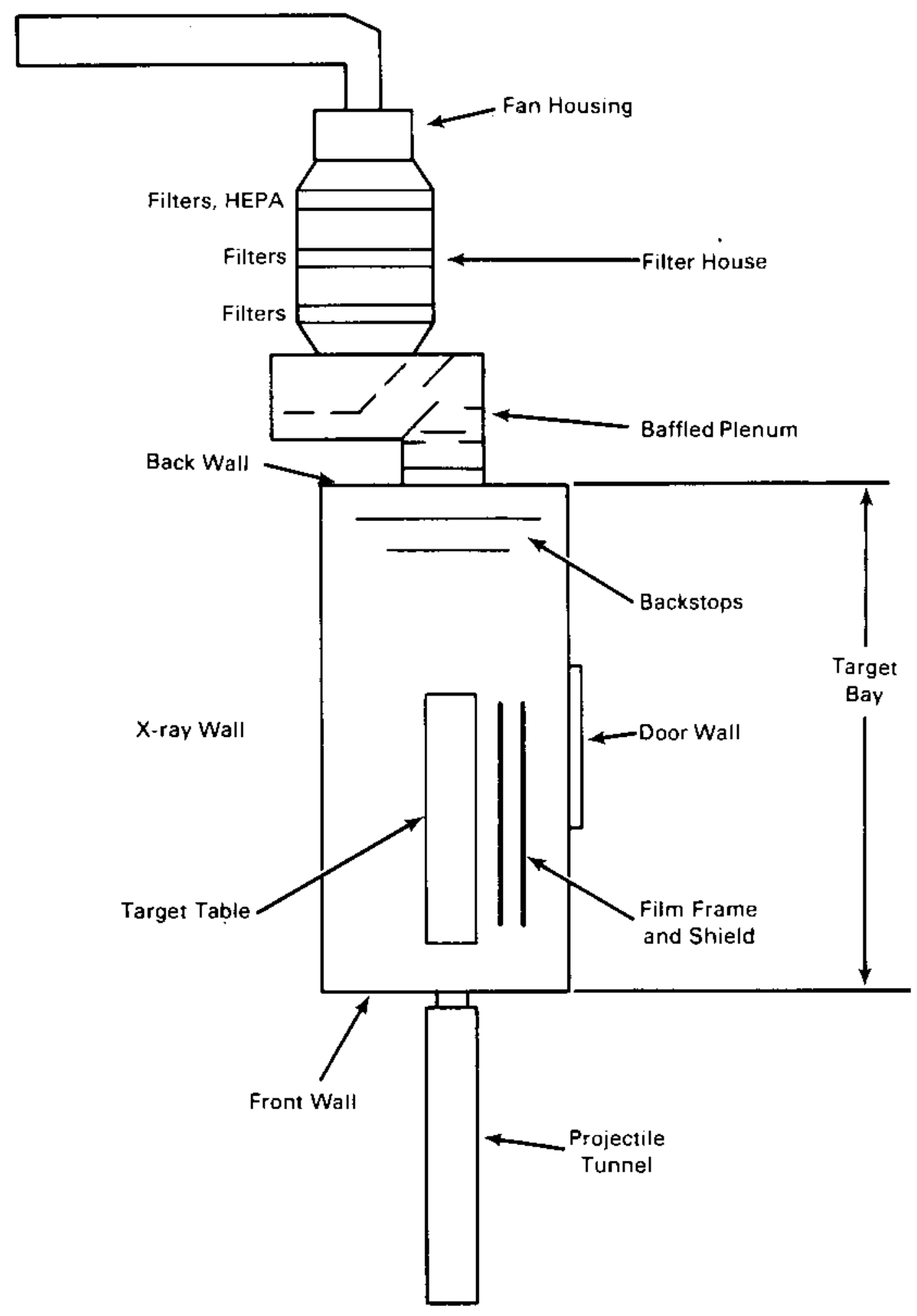

FIGURE 2.1. Generalized View of BTD Building 
$2.5 \mathrm{in}$. deep and held about $950 \mathrm{~g}$ of gravel. The top surface of the gravel in the tray is the calculated deposition surface and is $17.8125 \mathrm{in}^{2}$. The gravel in the trays was identical to that covering the floor, having been taken from the floor before the tests.

Nonaerosol DU was scooped or swept up for sampling. After each shot ( 3 shots per run) a visual survey of the target bay interior was made and large pieces of the penetrator and piles of DU ash were collected. Depleted uranium depositing in large amounts on equipment surfaces was swept up. Materials depositing on the plenum floor, in the filter house, and at the baffle entrance were also swept up for samples after selected runs.

\subsubsection{Coupon Samples}

Stainless steel coupons for collecting Du particles depositing on steel surfaces were attached to the various surfaces with screws, adhesive tape, or magnetic tape. Coupon dimensions were 1 in. by 5 in. For those coupons attached with magnetic tape, the tape covered one side of the coupon entirely for a total thickness of 0.11 in. Without tape backing, the coupons were 0.045 in. thick.

\subsubsection{Filter Samples}

Three banks of filters are located in the filter house as shown in Figure 2.1. Eighteen individual filters compose one entire bank. The original design configuration used for runs 0 and 1 consisted of the Farr 30/30 Flo 200, and HEPA (high-efficiency particulate air) filter banks in series. After run 1 , the pressure drop on the Riga-Flo $200^{\circledR}$ was excessive, indicating the first prefilter was not efficient enough. For subsequent runs (2 through 5) a Oust Trap ${ }^{\circledR}$ filter bank was added between the Farr 30/30 ${ }^{\circledR}$ and Riga-Flo $200{ }^{\circledR}$ banks. Table 2.1 gives information on the filter types and also indicates the runs for which they were sampled. The HEPA sample represented DU collected from all of the runs.

- Farr 30/30 and Riga-Flo 200 are registered tradenarks of the Farr Company, Los Angeles, California.

( D) Dust Trap is a registered trademark of the TRI-DIM Filter Corp., Hawthorne, New Jersey. 


\section{TABLE 2.1. Filter Sample Information}

$\begin{array}{lcccc}\text { Filter Type } & \begin{array}{c}\text { Approximate } \\ \text { Efficiency, } \%\end{array} & \begin{array}{c}\text { Depth, } \\ \text { in. }\end{array} & \begin{array}{c}\text { Folds } \\ \text { per Filter }\end{array} & \begin{array}{c}\text { Sampled } \\ \text { After Run }\end{array} \\ \text { HEPA } & 12 & 58 & 5 \\ \begin{array}{l}\text { Riga-F10 } \\ 200^{\circledR}\end{array} & 95 \text { (b) } & 12 & 16 & 1,5 \\ \text { Dust Trap } & 60^{(b)} & 2 & 21 & 2-5 \\ \text { Farr 30/30® } & 25 \text { (b) } & 4 & 21 & 0-5\end{array}$

(a) From Burchsted, Fuller and Kahn (1976)

(b) From ASHRAE 52-76 (1976).

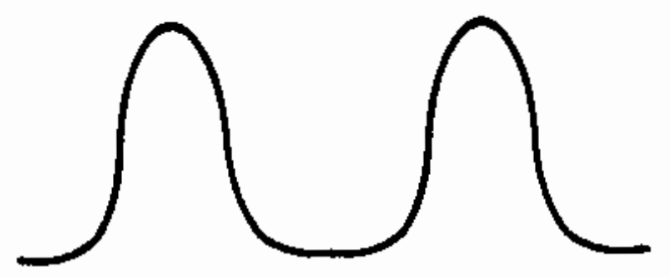

FIGURE 2.2. Typical filter Sample, Two Folds

Each air filter contains a sheet of filtration media that has been pleated, folded, or corrugated to maximize the available surface area contained therein. A typical filter sample consisted of two folds or pleats as shown in Figure 2.2. Two sets were extracted from selected filters. The identification of filters and folds is detailed in Section 2.2.

\subsection{SAMPLE LOCATIONS}

Tray, coupon, and filter samples represented various areas of the BTD facility. The location where samples were taken was determined by using random coordinates generated by a statistical program (MINITAB) to ensure that the experiment would provide valid data for the statistical analysis. This design allows an unbiased comparison of the total DU mass collected in different runs. Figure 2.3 is an expanded view of the enclosure, and Figure 2.4 is a 
view of the filter housing, showing the location designation of the areas sampled. Both letter and numerical designations are given. The letter designations are for the convenience of the reader; however, numerical designations were more convenient to use for the computerized data reduction.

Table 2.2 lists the coupon and tray samples, the corresponding areas they represent, and decodes the notations used in the figures and text to designate samples and sampling locations. The size of some sampled areas changed from run to run as noted in the table. The areas listed are described in the following section, which also details the selection of filter and scoop and sweep sample locations.

\subsubsection{Floor Tray and Scoop and Sweep Samples}

Floor (FL) Tray

The floor was divided into three sections: front, middle, and rear, as shown in Figure 2.5, with the exclusion areas identified (i.e., areas covered by equipment). Each third was sampled using two randomly located trays that were left in place for the three rounds in a run. A specific set of tray coordinates was used for each run.

$\underline{\text { Scoop and Sweep Samples }}$

Nonaerosol DU collected after each round was identified by a visual survey of the target bay interior. Any large pieces of the penetrator and any piles of DU ash were collected. Separate containers were used for each type of material. Depleted uranium in the plenum was swept up after runs 2 through 5. After the first three runs, we noticed material collecting in the baffie entrance, so sweepings from that area were also collected. They (the baffle entrance sweeps) represent runs 1,2 , and 3 (a composite) and runs 4 and 5 . The filter house was swept after runs 4 and 5 .

\subsubsection{Coupon Samples}

Coupons were held in place using magnetic tape where possible. Some of the surfaces were nonmagnetic or dynamic and therefore the coupons were fastened onto these areas with adhesive tape or screws. Coupons were screwed 

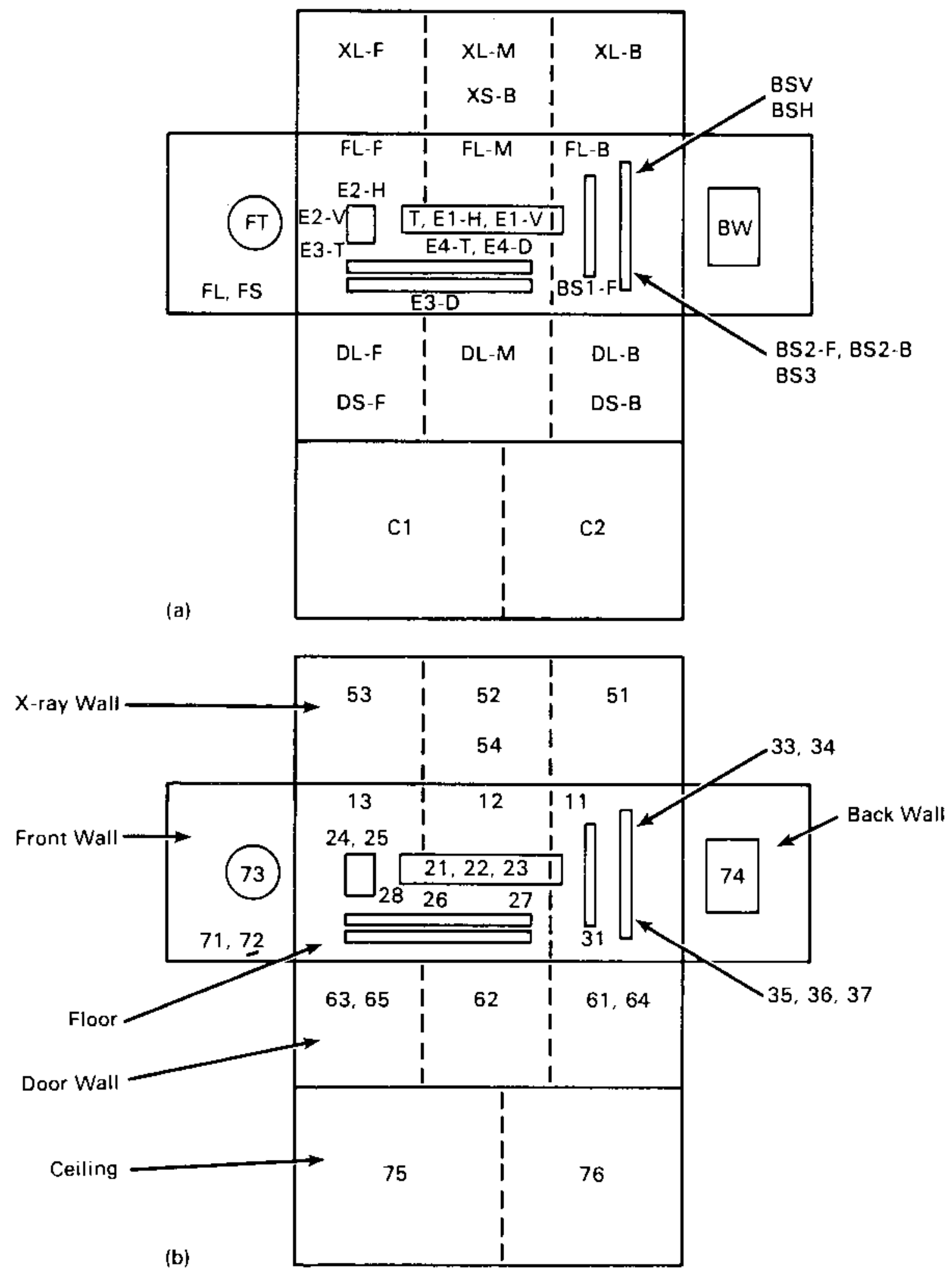

FIGURE 2.3. Exploded View of Enclosure Sampling Areas

(a) Sample Run Identification

(b) Numerical Designation in Sampling Runs 

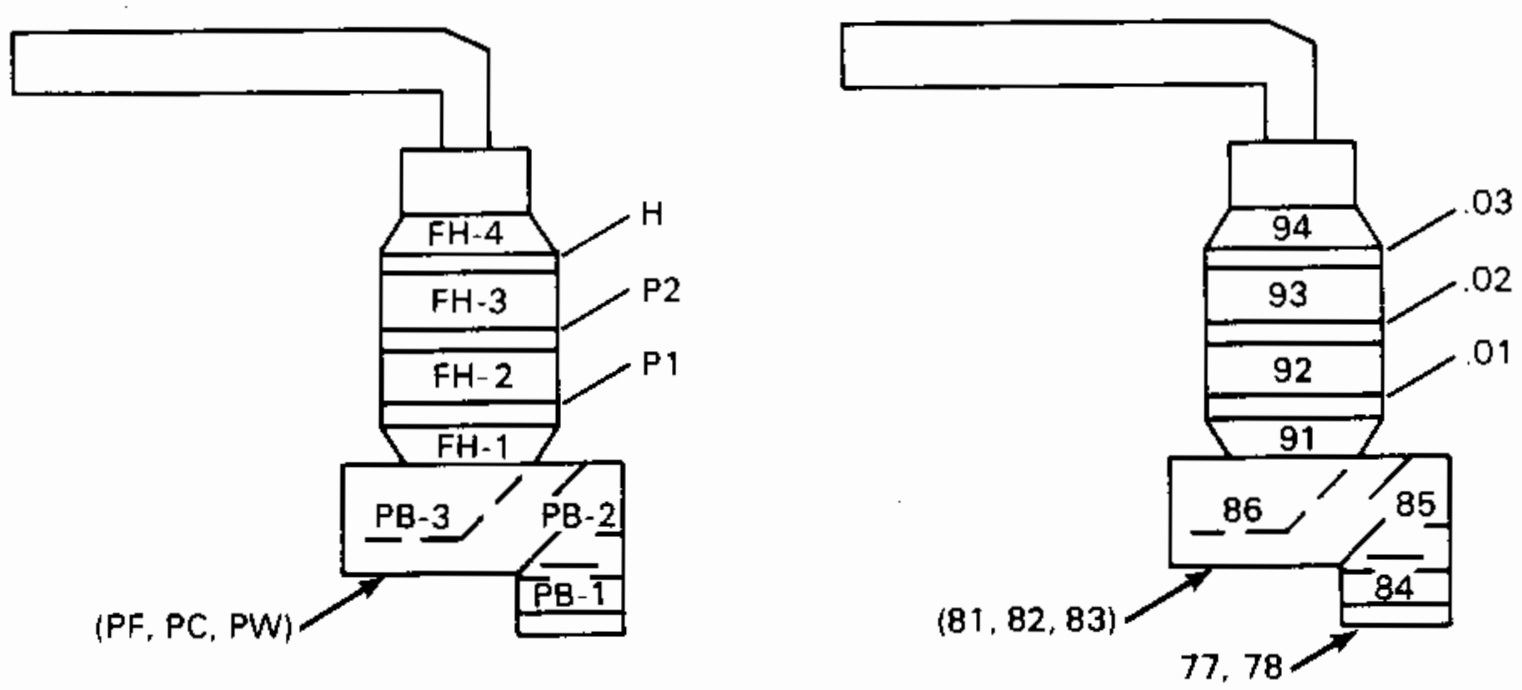

FIGURE 2.4. Filter House Sampling Areas

(a) Sample Area Identification

(b) Numerical Designation of Sampling

to the target, target side of the film shield, and exposed frontal areas of the first two backstop plates. Adhesive tape was used to tape some coupons to the $x$-ray table and part of the film frame. Some of the screwed coupons were blown from the surfaces by the force of the shot and were lost. 0thers were bent outward away from the surfaces they were screwed to, thus making both sides collection surfaces. The same coupon area of $0.044 \mathrm{ft}^{2}$ was used for all coupons collected.

\section{Equipment (E).}

Target, target table, x-ray table, film frame shield, film frame, and film frame support surfaces were represented by coupon samples. The tabies were divided into two areas, the horizontal and vertical surfaces. Inner surfaces of the film frame and shield were inaccessible for sampling. The areas of some of the target table and target equipment surfaces varied from run to run as shown in Table 2.2 .

The tables were divided into horizontal and vertical surfaces for sampling. Figure 2.6 shows the horizontal and vertical surfaces of the target table; 


\section{TABLE 2.2. Enclosure Areas Represented by Tray and Coupon Samples}

\begin{tabular}{|c|c|c|c|c|c|c|c|}
\hline Ared & $\begin{array}{l}\text { Loc } \\
\text { Code }\end{array}$ & $\begin{array}{r}10 C \\
10\end{array}$ & Description & $\begin{array}{l}\text { Area Represented } \\
\text { by Sample, } \mathrm{ft}^{2}\end{array}$ & & & \\
\hline Floor & $\begin{array}{l}11 \\
12 \\
13\end{array}$ & $\begin{array}{l}F L-B \\
F L=M \\
F L-F\end{array}$ & $\begin{array}{l}\text { Floor - Back Section } \\
\text { Floor - Middle Section } \\
\text { Floor - Front Section }\end{array}$ & $\begin{array}{l}272.6 \\
303.6 \\
353.6\end{array}$ & Run 1,3 & Run 2,4 & Run 5 \\
\hline Equi prent & $\begin{array}{l}21 \\
22 \\
23 \\
24 \\
25 \\
26 \\
27 \\
28 \\
29\end{array}$ & $\begin{array}{l}T \\
E 1-H \\
E 2-Y \\
E 2-H \\
E 2-Y \\
E 4-T \\
E 4-D \\
\text { E3-T } \\
E 3-D\end{array}$ & $\begin{array}{l}\text { Target } \\
\text { Target Table - Horizontal Surfaces } \\
\text { Target Table - Botton Surface } \\
\text { Target Table - Vertical Surface } \\
\text { Weldument } \\
\text { X-ray Table Hortzontal Surfaces - Botton } \\
\text { X-ray Table - Vertical Surfaces } \\
\text { Film Shield - Target Side } \\
\text { Fila Shield Supports } \\
\text { Film Frame Suppor Structure } \\
\text { X-ray Table - Horizontal Surfaces - Top } \\
\text { Film Frage - Door Side }\end{array}$ & $\begin{array}{l}0(a) \\
82.4 \\
60.5 \\
101.9 \\
77.5 \\
10.2 \\
12.2 \\
96.6 \\
11.6 \\
65.4 \\
10.2 \\
96.6\end{array}$ & $\begin{array}{r}21.8 \\
82.4 \\
60.5 \\
101.9 \\
77.3\end{array}$ & $\begin{array}{r}52.3 \\
82.4 \\
60.5 \\
101.9 \\
77.3\end{array}$ & $\begin{array}{r}13.4 \\
85.9 \\
60.5 \\
101.9 \\
15\end{array}$ \\
\hline Backstop & $\begin{array}{l}31 \\
33 \\
34 \\
35 \\
36 \\
37\end{array}$ & $\begin{array}{l}\text { BSL-F } \\
\text { BS2-F } \\
\text { BS2-B } \\
\text { BSV } \\
\text { BSH } \\
\text { BS3 }\end{array}$ & $\begin{array}{l}\text { Primary Plate - Front } \\
\text { Secondary Plate - Front } \\
\text { Secondary Plate - Back } \\
\text { Vertical Surfaces } \\
\text { Horizonta\} Surfaces } \\
\text { Additional Backup Plates }\end{array}$ & $\begin{array}{l}162 \\
294 \\
294 \\
94.7 \\
66.8 \\
818.6\end{array}$ & & & \\
\hline$x$-ray wa 11 & $\begin{array}{l}51 \\
52 \\
53 \\
54\end{array}$ & $\begin{array}{l}x L-B \\
x L-M \\
x L-F \\
X S-B\end{array}$ & $\begin{array}{l}\text { Liner Plate - Back } \\
\text { Liner plate - Middle } \\
\text { Liner Plate - Front } \\
\text { Space Around X-ray Opening }\end{array}$ & $\begin{array}{l}380.8 \\
380.8 \\
380.8 \\
256.9\end{array}$ & & & \\
\hline Door Wall & $\begin{array}{l}61 \\
62 \\
63 \\
64 \\
65\end{array}$ & $\begin{array}{l}D L-B \\
D L-H \\
D L-F \\
D S-B \\
D S-F\end{array}$ & $\begin{array}{l}\text { Liner Plate - Back } \\
\text { Door } \\
\text { Lf faer Plate - Front } \\
\text { Space - Back } \\
\text { Space - Front }\end{array}$ & $\begin{array}{l}406.7 \\
378 \\
406.7 \\
813.4 \\
813.4\end{array}$ & & & \\
\hline $\begin{array}{l}\text { End walls/ } \\
\text { Ceiling }\end{array}$ & $\begin{array}{l}71 \\
72 \\
73 \\
74 \\
75 \\
75 \\
77 \\
78\end{array}$ & $\begin{array}{l}\mathrm{FL} \\
\mathrm{FS} \\
\mathrm{FT} \\
\mathrm{BH} \\
\mathrm{C1} \\
\mathrm{C2} \\
\mathrm{BA} \\
\mathrm{BE}\end{array}$ & $\begin{array}{l}\text { Front Wall - L1ner Plate } \\
\text { Front Wall - Space Around } \\
\text { Tunnel Penetration } \\
\text { Tunnel } \\
\text { Back Wall } \\
\text { Ceiling - Front Half } \\
\text { Ceiling - Rear Half } \\
\text { Baffles } \\
\text { Baffle entrance }\end{array}$ & $\begin{array}{l}514.4 \\
45.9 \\
1265 \\
472.8 \\
643.4 \\
643.4 \\
155.3 \\
82.2\end{array}$ & & & \\
\hline Plenum & $\begin{array}{l}81 \\
82 \\
83 \\
84 \\
85 \\
86\end{array}$ & $\begin{array}{l}P F \\
P C \\
P W \\
P B-1 \\
P B-2 \\
P B=3\end{array}$ & $\begin{array}{l}\text { Floor } \\
\text { Cetling } \\
\text { Walls } \\
\text { Baffles - Set } 1 \\
\text { Baffles - Set } 2 \\
\text { Baffles - Set } 3\end{array}$ & $\begin{array}{l}202 \\
202 \\
357.1 \\
200.3 \\
121.7 \\
134\end{array}$ & Run 0.1 & & \\
\hline Filter House & $\begin{array}{l}91 \\
92 \\
93 \\
94\end{array}$ & $\begin{array}{l}\mathrm{FH}-1 \\
\mathrm{FH}-2 \\
\mathrm{FH}-3 \\
\mathrm{FH}-4\end{array}$ & $\begin{array}{l}\text { Plenum Transition Area } \\
\text { Area Between Primary and } \\
\text { Secondary Filters } \\
\text { Area Between Secondary and HEPA Filters } \\
\text { Area 8etween HEPA Filters and Fan House }\end{array}$ & $\begin{array}{l}278.9^{(b)} \\
483.7 \\
486.5 \\
304.0\end{array}$ & 255.1 & & \\
\hline
\end{tabular}

(a) No target in Run 0 . Values for other runs as indicated.

(b) Area sampled during all runs except 0 and 1. 


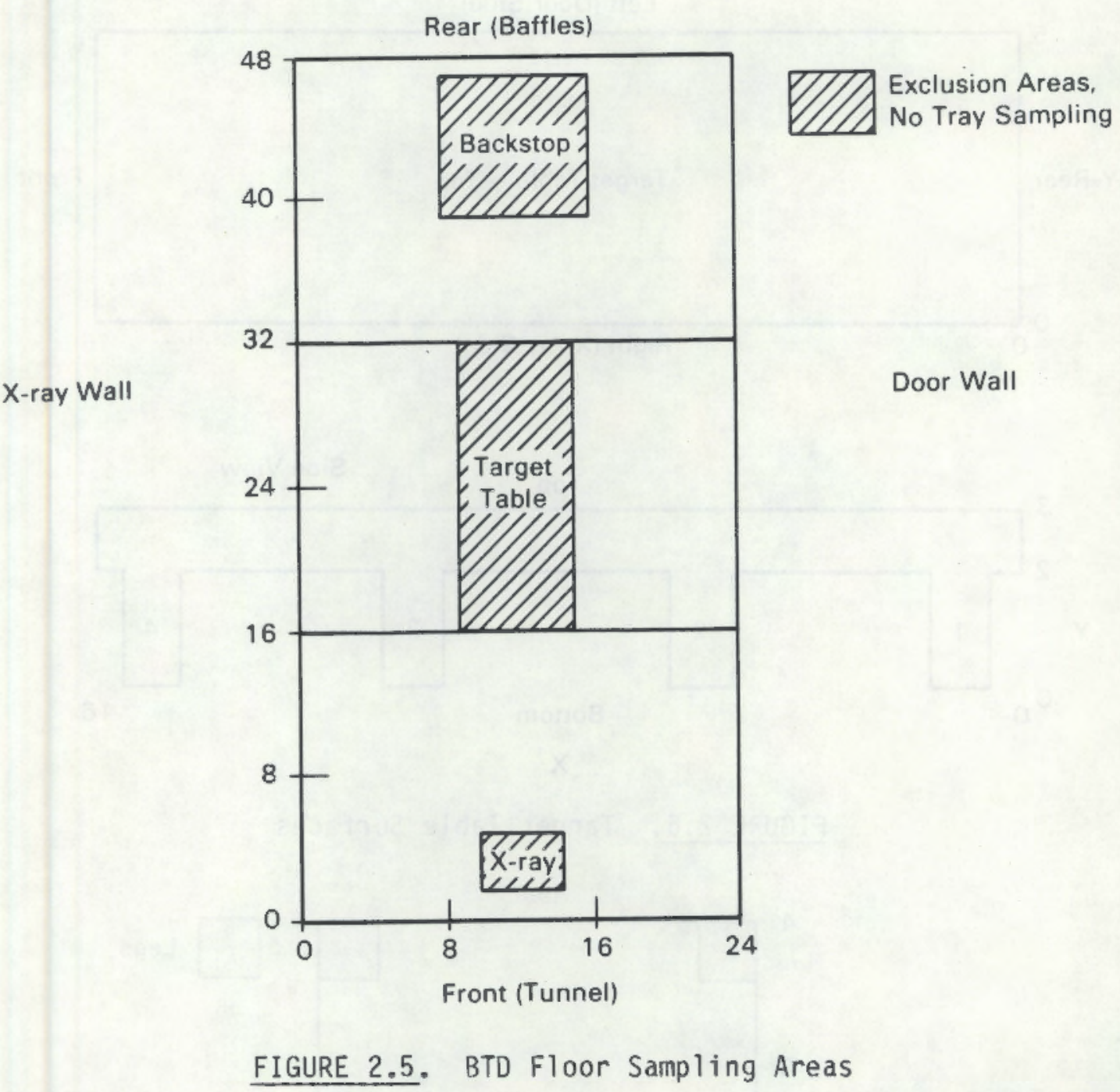

Figure 2.7 shows the overhead $x$-ray table. Sampler positions on the horizontal surfaces are described by the coordinates and vertical surfaces by positions on the support legs.

The shield and frame are divided into two sides: those facing the target and those facing the door wall of the building. Figure 2.8 shows the film frame and shield and the coordinates used in sampler placement.

\section{Backstop (B)}

Several backstop plates were located at the rear of the target bay. Figure 2.9 shows the plate positions and coordinates for sampler placement. The plates were divided into the following subareas for sampling: front of the 

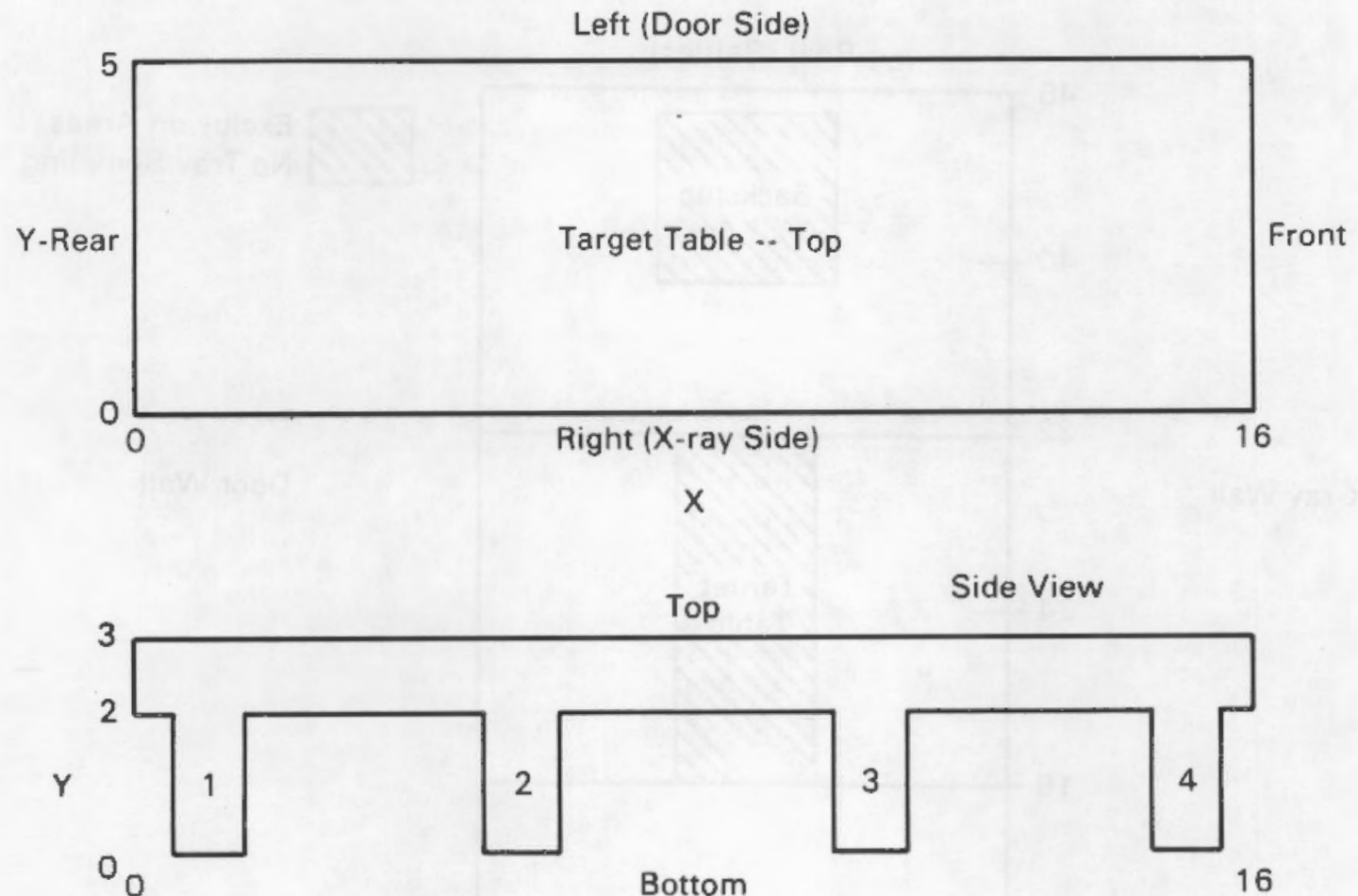

$\mathrm{X}$

FIGURE 2.6. Target Table Surfaces

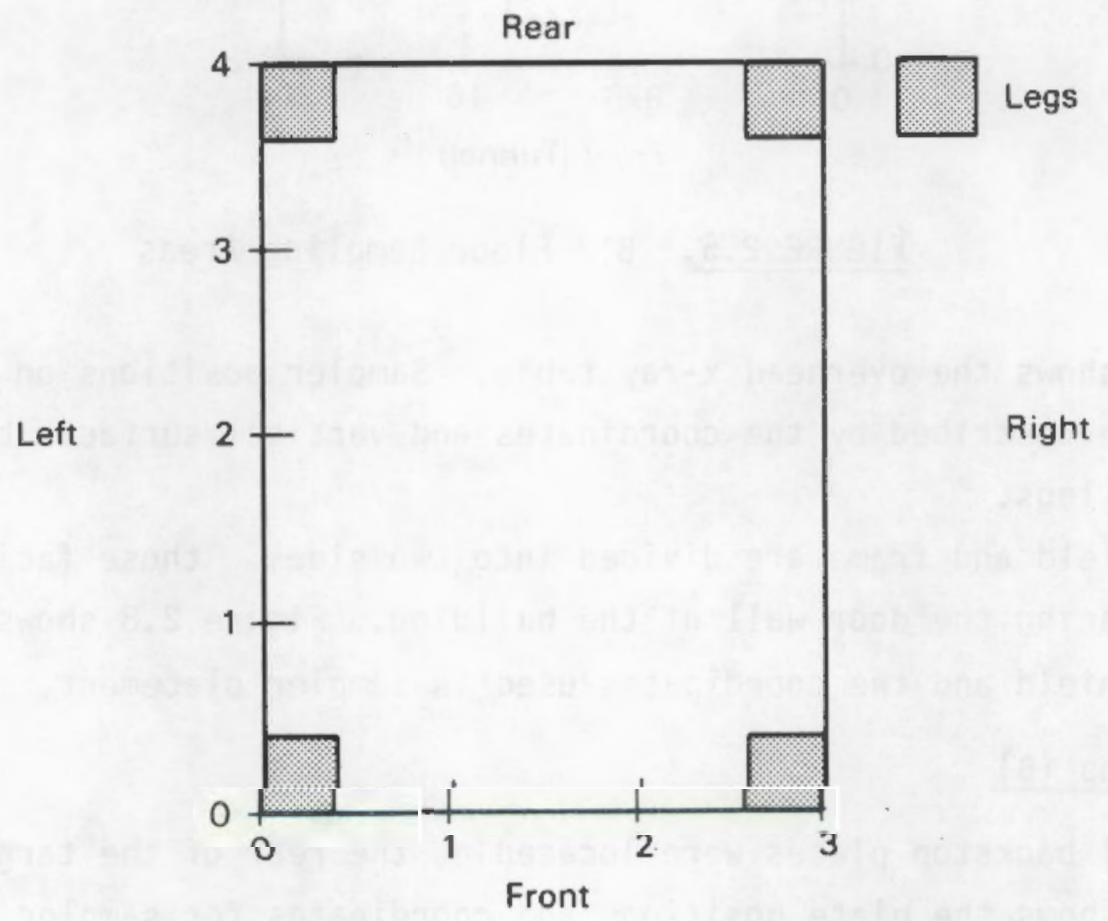

FIGURE 2.7. Overhead X-ray Table Surfaces 


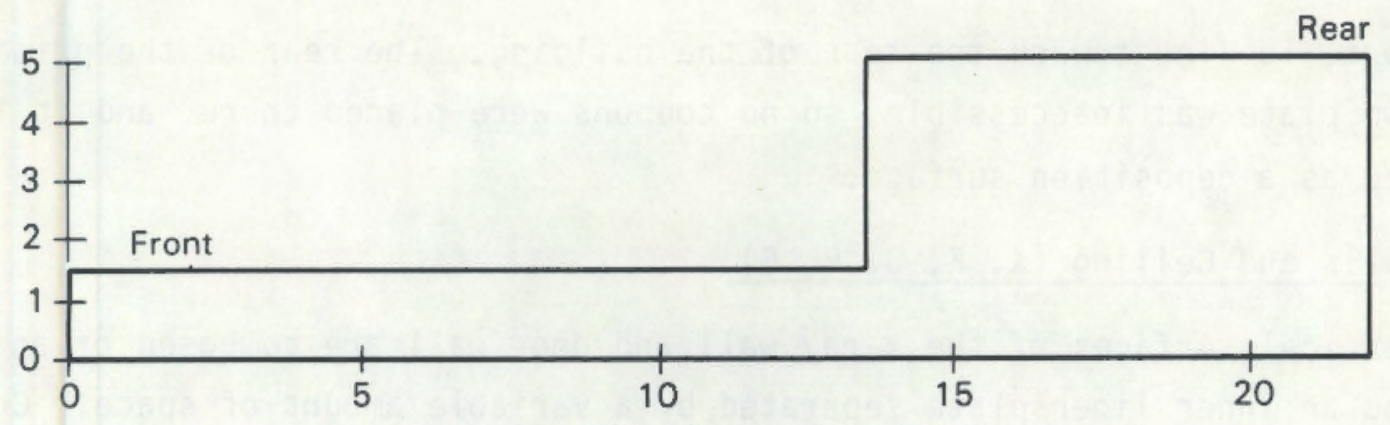

FIGURE 2.8. Coordinates for the Film Frame and Film Frame Shield From Door Side of Building
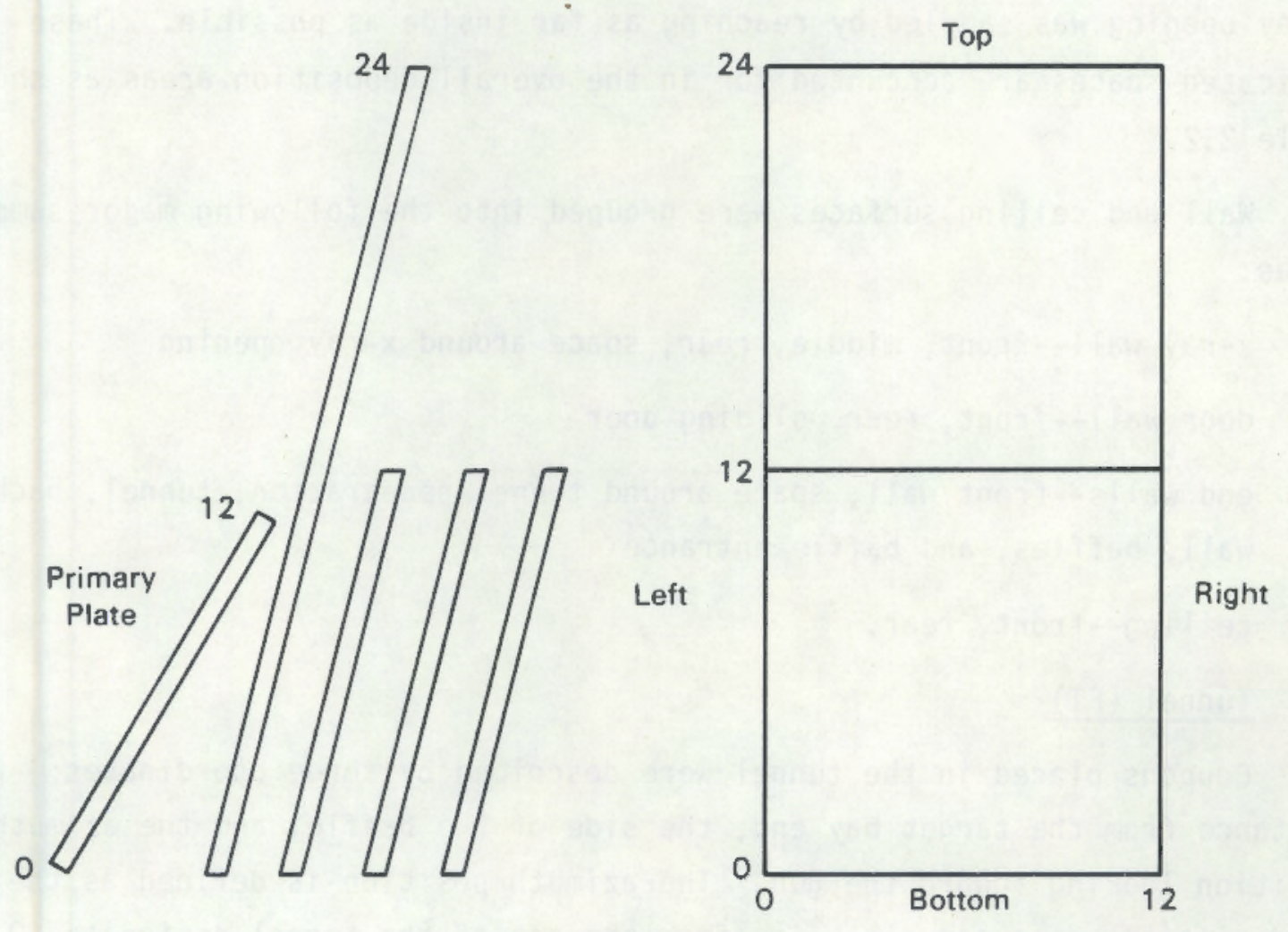

FIGURE 2.9. Side and Front View of Backstop Primary and Secondary Plates

primary plate, front and rear of the second plate, and vertical and horizontal components of the support structure, and the remaining backstop plates. All coupon positions were described as if the observer were facing the plates from 
the front, looking toward the rear of the building. The rear of the primary backstop plate was inaccessible, so no coupons were placed there, and it is not included as a deposition surface.

Walls and Ceiling (X, F, D, B, C)

Vertical surfaces of the x-ray wall and door wall are composed of an outer wall and an inner liner plate separated by a variable amount of space. Coupon samplers were concentrated on the exposed wall surfaces with additional coupons in accessible spaces. Inaccessible areas between the outer wall and the liner plates were either not sampled or sampled with difficulty; the space around the $x$-ray opening was sampled by reaching as far inside as possible. These indicated spaces are accounted for in the overall deposition areas as shown in Table 2.2.

Wall and ceiling surfaces were grouped into the following major sampling areas:

- x-ray wall--front, middle, rear, space around $x$-ray opening

- door wall--front, rear, sliding door

- end walls--front wall, space around tunnel penetration, tunnel, back wall, baffles, and baffle entrance

- ceiling--front, rear.

Tunnel (FT)

Coupons placed in the tunnel were described by three coordinates: the distance from the target bay end, the side of the baffle, and the azimuth position looking toward the gun. The azimuth position is defined as the angle of deviation, measured clockwise from the top of the tunnel designated 0 . These tunnel coordinates are shown in Figure 2.10.

Plenum $(P)$

The plenum connects the target bay to the filter housing (Figure 2.1) and contains baffles to reduce the shock impact on the filter system. It was divided into six sampling areas: floor, walls, ceiling, and three groups of baffles. A general view of the plenum showing the internal baffles is shown in 

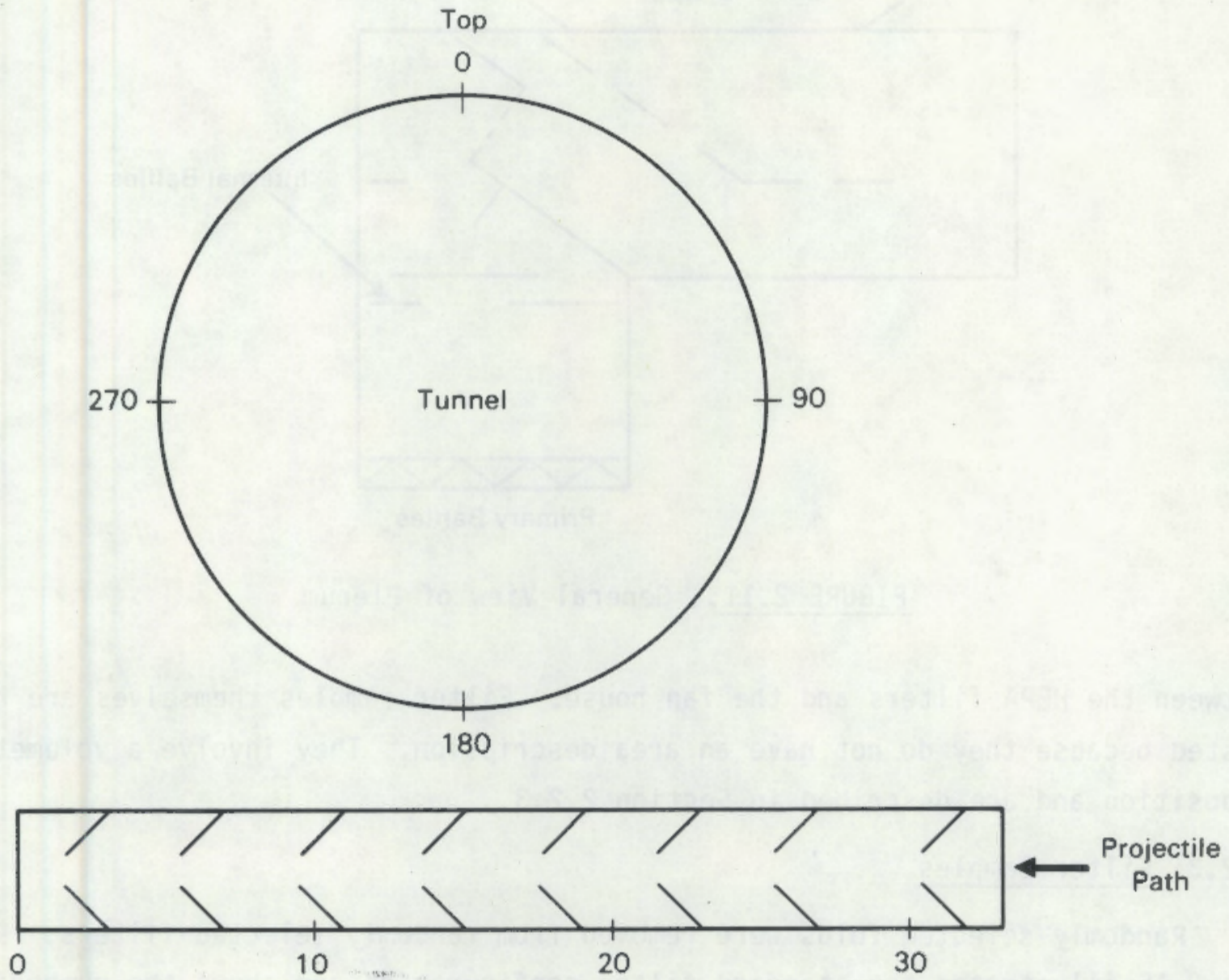

FIGURE 2.10. Tunnel Sampling Coordinates

Figure 2.11. Figure 2.12 shows the coordinates used in sampling the plenum floor, ceiling, and walls. Sampler coordinates for the three baffle groups are shown in Figure 2.13.

Filter House (FH)

The filter house has an exhaust fan house at one end and the plenum at the other. Sample areas listed in Table 2.2 represent deposition surfaces between the filter banks, and coordinates for coupon placement are shown in Figure 2.14. They are the plenum transition area, area between the primary and secondary filters, area between secondary and HEPA filters, and the area 


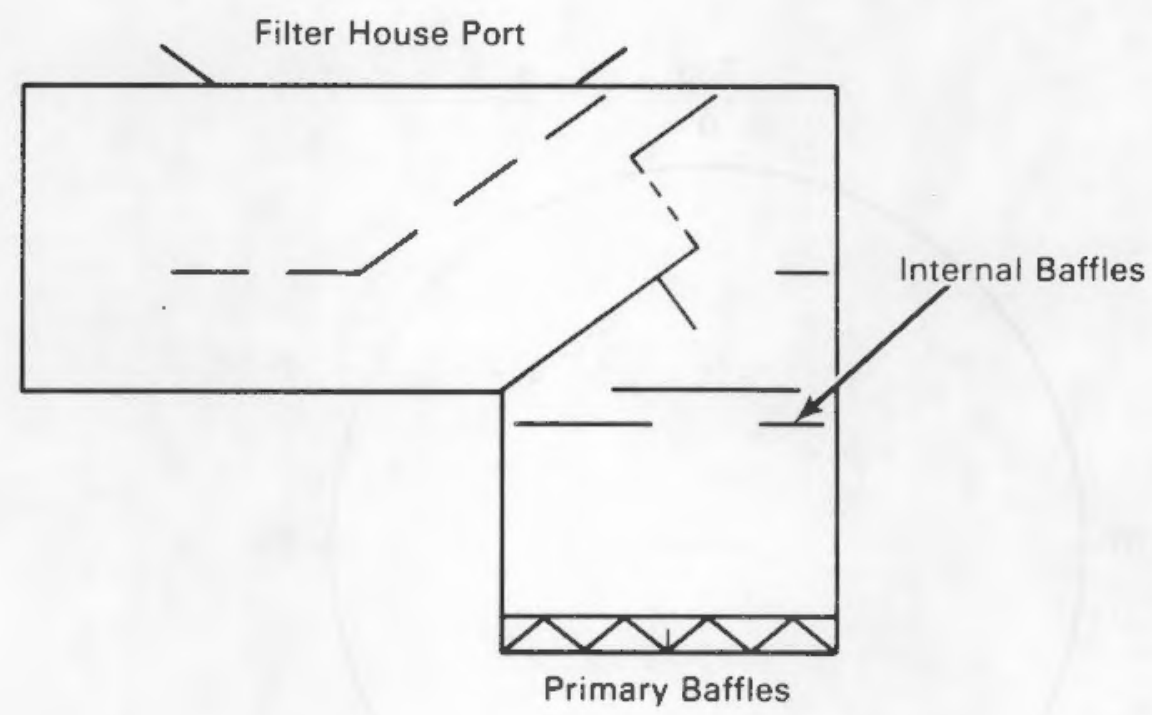

FIGURE 2.11. General View of Plenum

between the HEPA filters and the fan house. Filter samples themselves are not listed because they do not have an area description. They involve a volumetric deposition and are described in Section 2.2.3.

\subsubsection{Filter Samples}

Randomly selected folds were removed from randomly selected filters. Figure 2.15 illustrates the standard filter configuration and shows the numbering scheme for their location. All sample locations were identified while facing the direction of the airflow; fold locations were identified by counting left to right in the direction of airflow. The illustrated filter is 2,2 with sample folds 3 and 6 identified as the blacked out area. The first sample from filter 2,2 would consist of folds 3 and 4 and the second of folds 6 and 7 . The sample is related to the entire filter by the ratio of the total folds/sampled folds.

\subsection{DESCRIPTION OF RUNS}

Information on the shots, targets, and penetrators for each run are summarized in the data analysis section in Table 4.5 showing the coded 

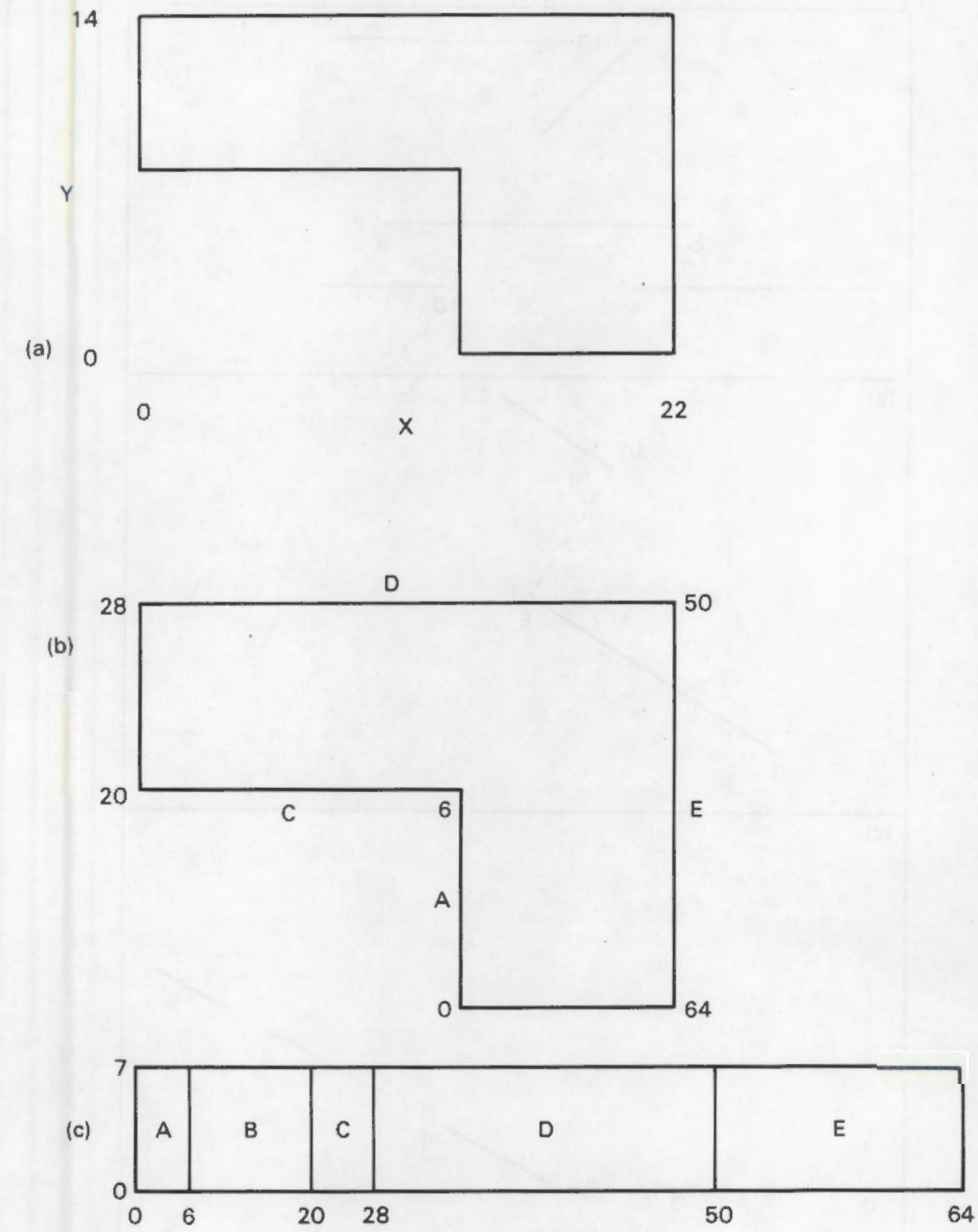

FIGURE 2.12. Sampling Coordinates for Plenum Floor, Ceiling, and Walls

(a) Plenum floor and ceiling

(b) Plenum wall top view showing $x$ coordinate

(c) Flattened view of plenum walls. 


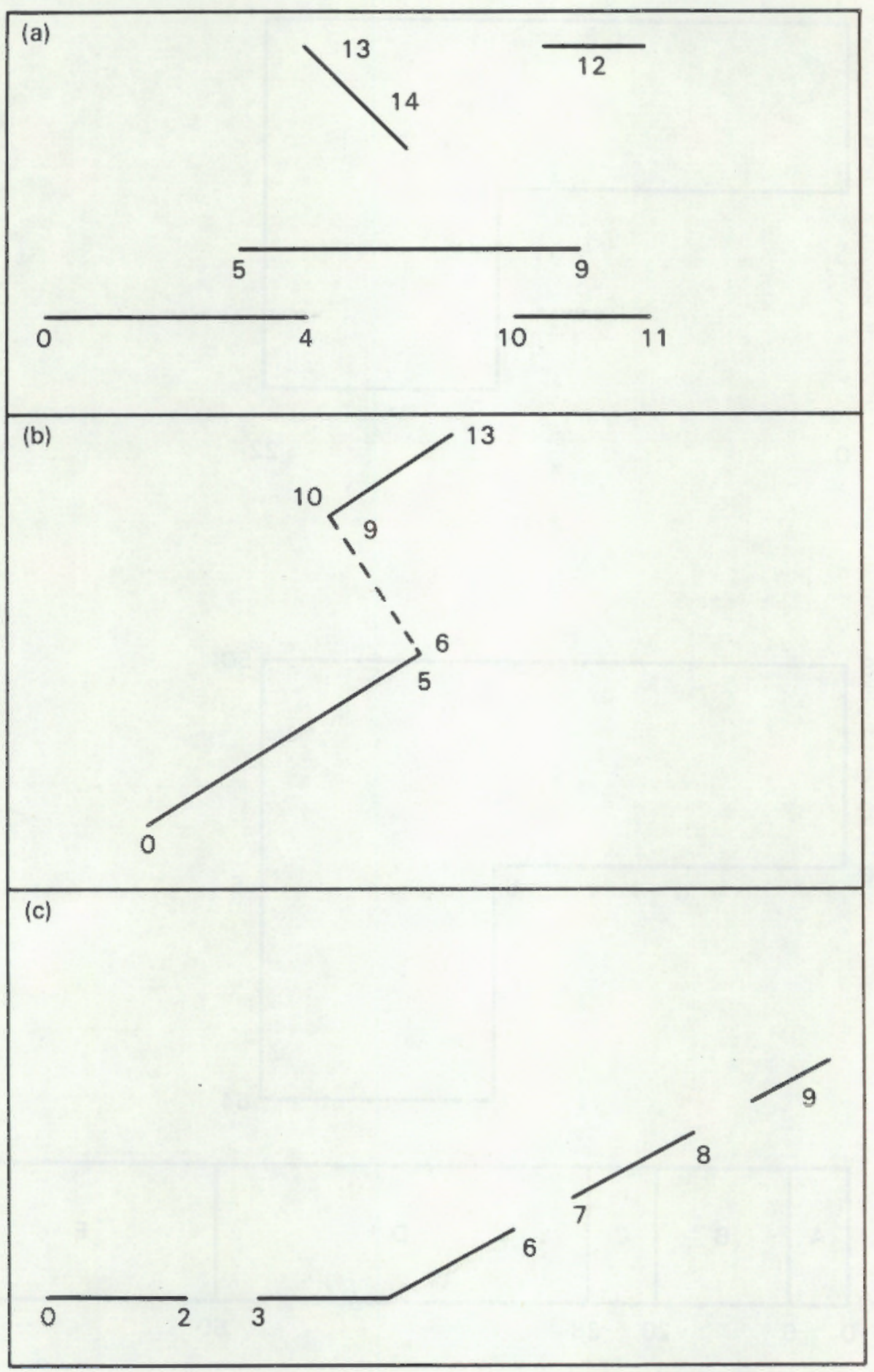

FIGURE 2.13. Plenum Baffle Sampling Coordinates

(a) PB-1

(b) $\mathrm{PB}-2$

(c) $\mathrm{PB}-3$ 


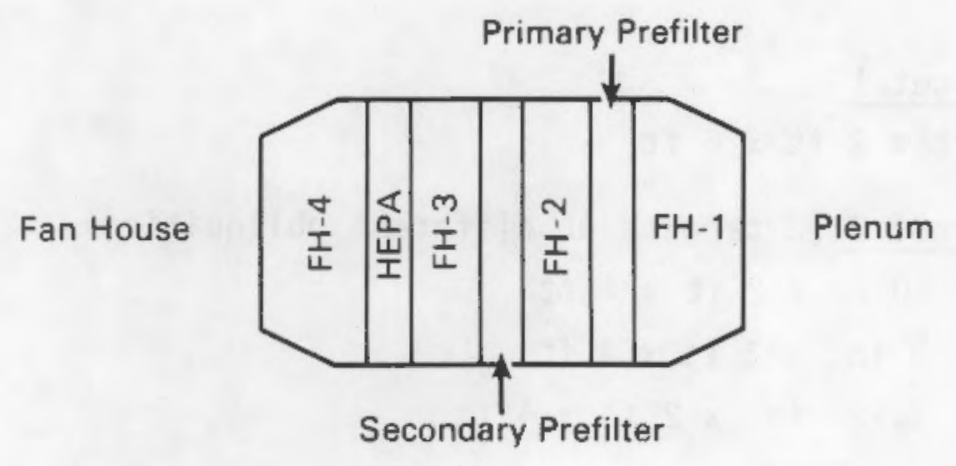

Each Area FH, Unfolds Into:

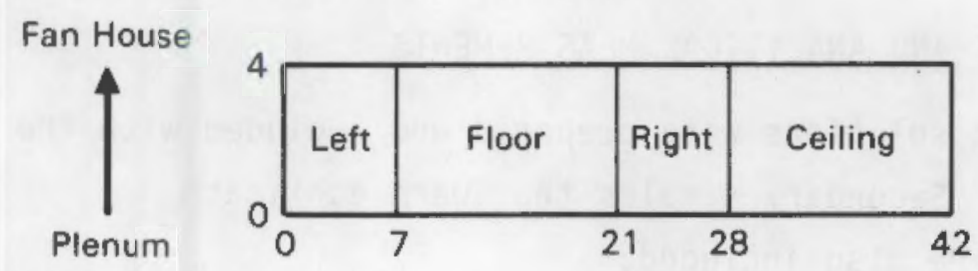

Facing Fan House

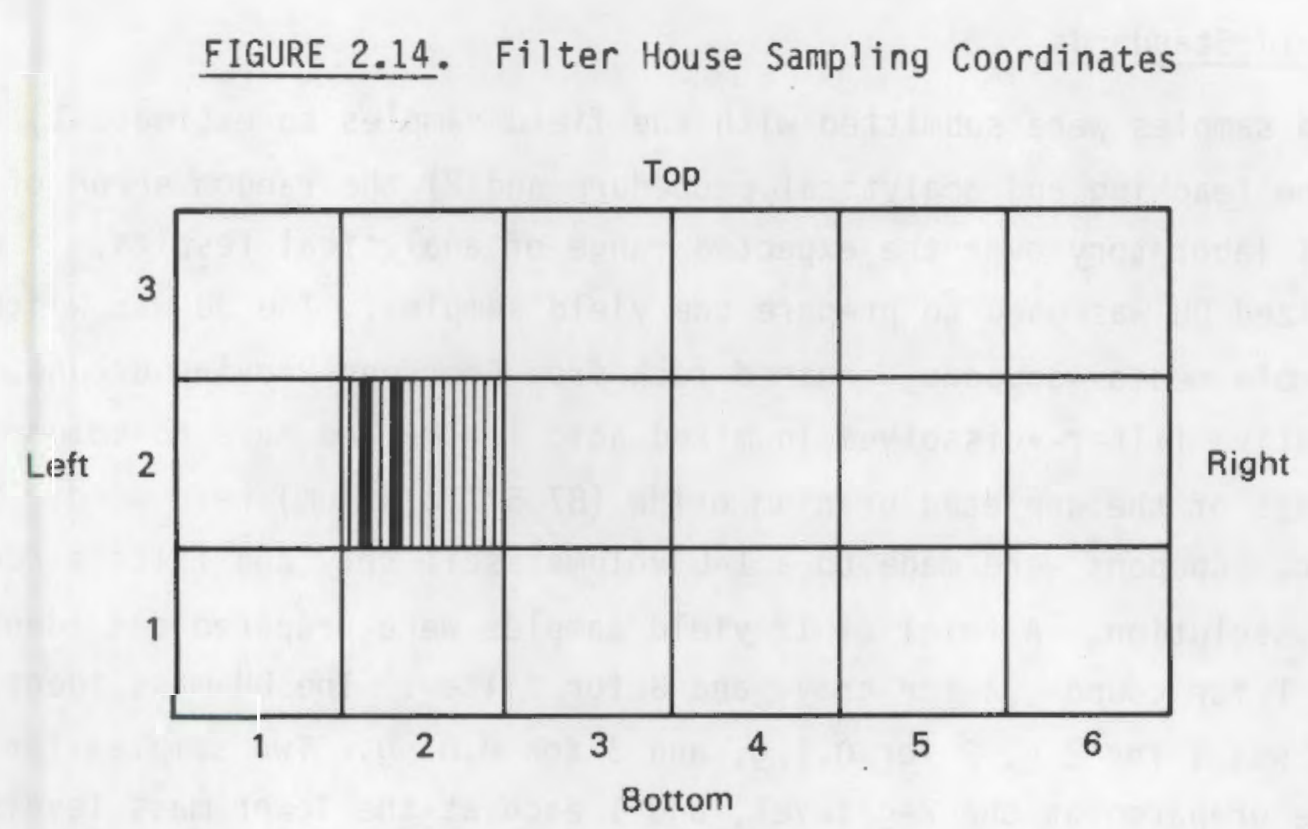

FIGURE 2.15. Filter Bank Coordinates

conditions for each shot. Each run consisted of three shots, for a total of 15 shots and 5 runs and a background run to investigate interferences. Three targets and two penetrator masses were used: 
Target 1

$2 \mathrm{ft} \times 2 \mathrm{ft} \times 6 \mathrm{ft}$

Target 2 ( 3 targets at different obliquities)

(a) $10 \mathrm{~mm} \times 2 \mathrm{ft} \times 4 \mathrm{ft}$

(b) 1 in. $\times 2 \mathrm{ft} \times 4 \mathrm{ft}$

(c) $3.125 \mathrm{in} . \times 2 \mathrm{ft} \times 4 \mathrm{ft}$

Target 3

18 in. $^{2} \times 600 \mathrm{~mm}$ deep on a $2-\mathrm{ft} \times 4-\mathrm{ft} \times 3-\mathrm{in}$. plate sitting on the rails.

\subsection{QUALITY CONTROL FOR LEACHING AND ANALYTICAL MEASUREMENTS}

Yield standards and standard solutions were prepared and included with the field samples sent for analysis. Secondary samples that were duplicate aliquots of the field samples, were also included.

\subsubsection{Yield Standards}

Yield samples were submitted with the field samples to estimate 1) the bias in the leaching and analytical procedure and 2) the random error of the analytical laboratory over the expected range of analytical results. A wellcharacterized DU was used to prepare the yield samples. The DU was weighed onto a sample media--coupons, crushed rock from Aberdeen Proving Ground, or a representative filter--dissolved in mixed acid leach, and made to volume. Three masses of the depleted uranium oxide ( $87.57 \%$ uranium) were used: $2,0.1$, and $0.01 \mathrm{~g}$. Coupons were made to a $1-L$ volume; soil tray and filters required $2 \mathrm{~L}$ for dissolution. A total of 12 yield samples were prepared and identified by code: 1 for coupon, 2 for tray, and 3 for filter. The DU mass identification code was 1 for $2 \mathrm{~g}, 2$ for $0.1 \mathrm{~g}$, and 3 for $0.01 \mathrm{~g}$. Two samples for each media were prepared at the $2-\mathrm{g}$ level, and 1 each at the lower mass levels.

\subsubsection{Standard Solutions}

The goals for the standard solution analysis were to estimate the bias of the analytical laboratory results and the random error of the analytical method. A stock uranyl nitrate hexahydrate (UNH) solution was used to prepare standard solutions to send with the field samples. The standard solutions were prepared using the successive dilution method. A nominal $100 \mathrm{~g} / \mathrm{L}$ stock 
solution was used to make the standard solutions, 3 batches at 3 concentration levels, $1 \mathrm{~g} / \mathrm{L}, 0.1 \mathrm{~g} / \mathrm{L}$, and $0.001 \mathrm{~g} / \mathrm{L}$ uranium. Chemical analysis of the stock solution showed it had an actual concentration of $101.85 \mathrm{~g} / \mathrm{L}$.

2.4.3 Secondary Samples

Secondary aliquots from leachates of the field samples were sent for analysis to estimate the sampling variability.

\subsection{SAMPLE SUMMARY}

A total of 468 field (including background), yield, standard, and secondary samples were analyzed. The quality control samples were distributed randomly through the field samples. A majority of the yield samples submitted were coupon yield because they constituted the bulk of the field samples. The number of field samples are listed by sampler type in Table 4.1 in the data analysis section. 


\subsection{CHEMICAL ANALYSIS}

The following sections discuss the preparation of the samples for chemical analysis and some observations made during the work. This is followed by a description of the methods used for sample analysis.

\subsection{SAMPLE PREPARATION}

The field samples were leached in an acid mixture of $5 \mathrm{~N}$ nitric and $0.05 \mathrm{~N}$ hydrofluoric acids to dissolve the uranium. The leachate bearing the uranium was separated from the sample media by filtering, and then made to a known volume for the chemical analysis.

The various sample media required different amounts of leach solution to cover then for the uranium dissolution. Volumes prepared for the chemical analysis for each media were

$\begin{array}{ll}\text { Coupons } & 1 \mathrm{~L} \\ \text { Tray soil, field, and yield } & 2 \mathrm{~L} \\ \text { Scoop and sweep } & 1 \text { or } 2 \mathrm{~L} \\ \text { Filter yield } & 2 \mathrm{~L} \\ \text { Filters } & 4 \text { to } 8 \mathrm{~L}\end{array}$

Coupons composited to form samples representing a single area were leached together. A single leaching could contain as many as eight coupons. Large DU fragments in tray soil were dissolved and analyzed separately for the first two runs. Later, fragments and soil were processed together in one leach.

The filter field samples proved difficult to work with because they were fairly large, and the uranium aerosol was embedded through the entire matrix. Early leaches indicated that only about $85 \%$ of the DU was leached from the filters in a single treatment. Recovery was based on two leaches, the second giving an additional 15\%. It was assumed that two leaches would be adequate because the filter yield samples should estimate the leaching procedure. Therefore, two leaches were used for all of these samples. Leachate aliquots from both treatments were combined to send for analysis. 
In most treatments, only the DIJ dissolved. The stainless steel coupons did not dissolve. For the filter samples, metal portions (wires or aluminum) dissolved and the filter disintegrated but did not dissolve. Cardboard portions of the filter did not dissolve or disintegrate. Soil did not dissolve, but the fine particles formed a colloidal suspension that was difficult to filter. These samples were centrifuged to separate the leachate froin the soil.

Filter and tray soil yield samples were leached in the same manner as the field samples. The UNH standard solutions were already dissolved, so they needed no special treatment before analysis.

\subsection{SAMPLE ANALYSIS}

Three analytical methods were used: kinetic laser fluorometry for the samples, ferrous sulfate-potassium dichromate titrimetry to determine the uranium concentration for the UNH standard stock solution, and a gross alpha scintillation and alpha energy count to determine the specific activity of the collected uranium. Some of the identifiable large pieces of DU were weighed to determine their mass.

\subsubsection{Kinetic Laser Fluorometry}

Kinetic laser fluorometry of time-resolved emission of the uranyl ion was selected and used for the entire range of sample solutions. Kinetic laser fluorometry has been developed at PNL (Bushaw 1984) and is suitable for use when there are a large number of samples. In this method, pulsed-dye laserexcitation with multichannel scaler photon counting is used to obtain timeresolved emission spectra of uranyl ions in aqueous solution. Kinetic analysis of these data corrects for matrix quenching and temperature effects, which can reduce the quantum yield of the uranyl ion luminescence. A standard uranium stock solution, prepared from New Brunswick Laboratory standard reference $\mathrm{U}_{3} \mathrm{O}_{\mathrm{g}}$, was used to calibrate the instrument. Detection limits can be as low as 1 part per trillion (pptr), and in samples with concentrations greater than 100 pptr, relative standard deviations of less than $3 \%$ are achieved routinely. 


\subsubsection{Ferrous Sulfate-Potassium Dichromate Titrimetry}

An aliquot of an approximately $510 \mathrm{~g} / \mathrm{L}$ uranium stock solution was used to make a $100 \mathrm{~g} / \mathrm{L}$ solution for preparation of the more dilute standard solutions. Uranium in this second UNH stock solution was measured using ferrous sulfate-potassium dichromate titrimetry (ASTM 1983). In this technique, an excess of ferrous sulfate is used to reduce uranium in concentrated phosphoric acid solution containing sulfamic acid. Excess iron is oxidized by nitric acid, and then the sample is titrated with potassium dichromate (prepared using a National Bureau of Standards potassium dichromate) to a potentiometric end point. The stated limit of error at the $95 \%$ confidence level is $\pm 0.1 \%$.

\subsubsection{Alpha Counting}

Total alpha content was determined on a dissolved uranium fragment by counts on a gross alpha scintillation system. The ratio of ${ }^{238} \mathrm{U}$ to ${ }^{234} \mathrm{U}$ was determined by counting on an alpha energy spectrometer. The efficiencies of both counting systems were determined using a calibrated plutoniuin standard source. The sample standard deviation was 5\%, computed using error propagation on counting errors and the variation of replicate samples.

The $235 \mathrm{U}$ content was essentially negative, so for calculation, the sample was assumed to consist of only $238 U$ and $234 U$ in the determined ratio of 8 to 1. The calculated total specific activity including both nuclides was $3.08 \times$ $10^{-7} \mathrm{Ci} / \mathrm{g}$. 



\subsection{DATA ANALYSES}

\subsection{DATA BASE}

A listing of the basic data is given in Appendix $A$, which also includes the coding form that defines the contents of the listing. This listing has the 356 gravimetric and laser fluorometry results for the samples from the five experimental runs. The background (run zero) results are not included in the listing because they did not reveal significant interferences. Analysis of the data showed that the coupons for run zero had a median concentration of $0.004 \mathrm{mg} / \mathrm{L}$, only $0.015 \%$ of the median for run 1 and 2 coupons. Table 4.1 gives the total number of samples of each type and the total number of analyses.

As discussed in Section 2, coupons were used to sample deposition to surfaces in the BTD building, including deposition in the projectile entry tunnel, plenum, and filter house. Scoops were used to pick piles of ash and nonaerosol uranium from the floor after each round. Large uranium pieces were separated from the ash and soil; the pieces were weighed and the ash leached. All other samples were leached, and the leachate was analyzed to determine milligrams of uranium per liter.

A total of 316 exposed, composited samples were collected and shipped to PNL. After leaching, 30 additional aliquots were made up from the leachate and sent for analysis to serve as replicates to check on the repeatability of the leachate sampling and analysis. In addition, one ash sample was subjected to two leachings, and nine of the tray samples (for runs 1 and 2) were leached twice and analyzed separately. After run 2, the tray samples were leached once, and filter samples were leached twice. The leachates were sampled and composited for analysis. Two of the composited coupon samples had no sampling location associated with them, and were removed from the analysis leaving 314 samples. Results for the two analyses for samples with replicates were averaged to provide the sample result. 
TABLE 4.1. Number of Samples and Analyses

\begin{tabular}{|c|c|c|c|c|c|}
\hline $\begin{array}{l}\text { Sample } \\
\text { Type }\end{array}$ & Code & Samples & Replicates & 2nd Leach & $\begin{array}{c}\text { Total } \\
\text { Analyses }\end{array}$ \\
\hline Coupon & 2 & 207 & 18 & & 225 \\
\hline $\begin{array}{l}\text { Scoop } \\
\text { Ash } \\
\text { Particles }\end{array}$ & $\begin{array}{l}3 \\
3\end{array}$ & $\begin{array}{l}15 \\
15\end{array}$ & 2 & 1 & 33 \\
\hline Tray & 4 & 30 & 6 & 9 & 45 \\
\hline Filter & 5 & 38 & 3 & (a) & 41 \\
\hline Sweep & 6 & 11 & 1 & - & 12 \\
\hline Total & & 316 & 30 & 10 & 356 \\
\hline
\end{tabular}

(a) Both leaches combined for filter sample analyses

\subsection{CALCULATIONS}

Two calculations were made to summarize the uranium collected: first, the grams of uranium for each location, then the grams of uranium/ $\mathrm{ft}^{2} / \mathrm{run}$ and round.

\subsubsection{Total Uranium}

The grams of uranium for each location sampled were calculated using expansion factors based on the ratio of the area sampled to the area of the sampler used. The basic equation used was

$$
\text { GTA }=\left(\frac{S Q \cdot F T}{K}\right)\left(\frac{\text { LEACH }}{\text { NCMP }}\right)(0.001 \times D U)
$$

where

$$
\begin{aligned}
\text { GTA } & =\text { the total grams uranium for a sampled location } \\
\text { SQ. FT } & =\text { the surface area for a location } \\
K & =\text { the surface area of the sampler } \\
\text { LEACH } & =\text { the liters of leachant used to dissolve the composited sample } \\
\text { NCMP } & =\text { the number of sanples composited in a leached sample }
\end{aligned}
$$


DU = the laser fluorometry result in milligrams of uranium per liter. Multiplying by 0.001 converts milligrams to grams.

The names assigned to the variables in Equation (1) are those used in the computer files.

In Equation (1), the ratio SQ. FT/K is the expansion factor, named SEXP in the computer files. For coupons, $K$ was $0.043889 \mathrm{ft}^{2}$ and for trays $0.123698 \mathrm{ft}^{2}$. For filters, SEXP was the total number of folds in a filter bank, 18 filters times the number of folds per filter (as in Table 2.1). This gave SEXP of 378 for the prefilters (Farr 30/30 and Dust Trap), 288 for the 90\%, and 1044 for the HEPA filters. The scoop and sweep samples had no area directly associated with them and were usually collected after each round (the other samplers were usually left in place for three rounds at least). The scoop and sweep samples were treated as special collections of nonaerosol material, and SEXP was set to unity for them.

\subsubsection{Uranium Per Square Foot}

The second quantity of interest is the grams of uranium per square foot for the run and round. The value per round was calculated using the run collection for trays, coupons and filters:

$$
G / U / R=G T A /(U N I T S \times \text { RDUNDS) }
$$

where

$$
\begin{aligned}
G / U / R= & \text { the grams per unit per round, } \\
\text { UNITS = } & \text { the } \mathrm{ft}^{2} \text { area for the location for trays and coupons or number of } \\
& \text { filters per bank }(18), \text { for filters, } \\
\text { ROUNDS = } & \text { the number of rounds represented by the sample. }
\end{aligned}
$$

The quantity (UNITS $x$ ROUNDS) was called WT, and used to calculate weighted averages for summaries that aggregated sampling locations into larger areas and over runs for the experiment total. In the summaries, an area of (23 in. $x$ $23 \mathrm{in.} / 1444$, or $3.6736 \mathrm{ft}^{2}$ was used to put the filter results on a square foot basis. 
The locations were aggregated using the location codes as shown in Table 4.2. The 51 basic locations were aggregated to 20 first-level summary areas (SLID), then to ten second-level areas (SMRY), then to six third-level areas (PLOT).

TABLE 4.2. Aggregation of Sampling Locations for Summaries

\begin{tabular}{|c|c|c|c|c|c|}
\hline Sampler & Area & $\begin{array}{l}\text { Location } \\
\text { Codes } \\
\end{array}$ & $\begin{array}{l}\text { First-Level } \\
\text { Summary } \\
\end{array}$ & $\begin{array}{l}\text { Second-Level } \\
\text { Summary }\end{array}$ & $\begin{array}{c}\text { Third-Leve } 1 \\
\text { Sumrnary }\end{array}$ \\
\hline Tray & Floor & $11,12,13$ & 1 & 1 & $T$ \\
\hline Scoops & $\begin{array}{l}\text { Ash } \\
\text { Particles }\end{array}$ & $\begin{array}{l}41 \\
41\end{array}$ & $\begin{array}{l}2 \\
3\end{array}$ & $\begin{array}{l}2 \\
2\end{array}$ & $\begin{array}{l}S \\
S\end{array}$ \\
\hline Coupons & $\begin{array}{l}\text { Target } \\
\text { X-ray table } \\
\text { Film frame } \\
\text { Backstop } \\
\text { Baffles } \\
\text { X-ray wall } \\
\text { Door wall } \\
\text { Front wall } \\
\text { Back wall } \\
\text { Ceiling } \\
\text { Tunnel } \\
\text { Plenum } \\
\text { Filter house }\end{array}$ & $\begin{array}{l}21,22,23 \\
24,25,28 \\
26,27,29 \\
31-37 \\
77,78 \\
51-54 \\
61-65 \\
71-72 \\
74 \\
75,76 \\
73 \\
81-86 \\
91-94\end{array}$ & $\begin{array}{r}4 \\
5 \\
6 \\
7 \\
13 \\
8 \\
9 \\
10 \\
12 \\
14 \\
11 \\
15 \\
16\end{array}$ & $\begin{array}{l}3 \\
3 \\
3 \\
4 \\
5 \\
6 \\
6 \\
6 \\
6 \\
6 \\
7 \\
8 \\
8\end{array}$ & $\begin{array}{l}E \\
E \\
E \\
E \\
W \\
W \\
W \\
W \\
W \\
W \\
W \\
P \\
P\end{array}$ \\
\hline Filters & $\begin{array}{l}\text { Prefilter } \\
90 \% \\
\text { HEPA }\end{array}$ & $\begin{array}{l}00,01,02 \\
03 \\
04\end{array}$ & $\begin{array}{l}18 \\
19 \\
20\end{array}$ & $\begin{array}{l}g \\
9 \\
9\end{array}$ & $\begin{array}{l}F \\
F \\
F\end{array}$ \\
\hline Sweeps & $\begin{array}{l}\text { Plenum } \\
\text { Filter house }\end{array}$ & $81-94$ & 17 & 10 & $P$ \\
\hline
\end{tabular}

\subsection{SUMMARY OF RESULTS}

An overall summary of results is given in figure 4.1 , which shows how the total grams of DU were apportioned into the third-level summary areas as a percentage of the total projectile weight for each RUN ( 3 rounds) and the total experiment. Table 4.3 has the data used in the plot 1 isted by summary areas. Table 4.4 lists the amount accounted for as percent of the projectile weight. Overa $11,81.3 \%$ of the total $63-\mathrm{kg}$ weight of the 15 projectiles was recovered. The percent recovery ranged from a high of $97.7 \%$ in run 1 to a low of $65.2 \%$ in 


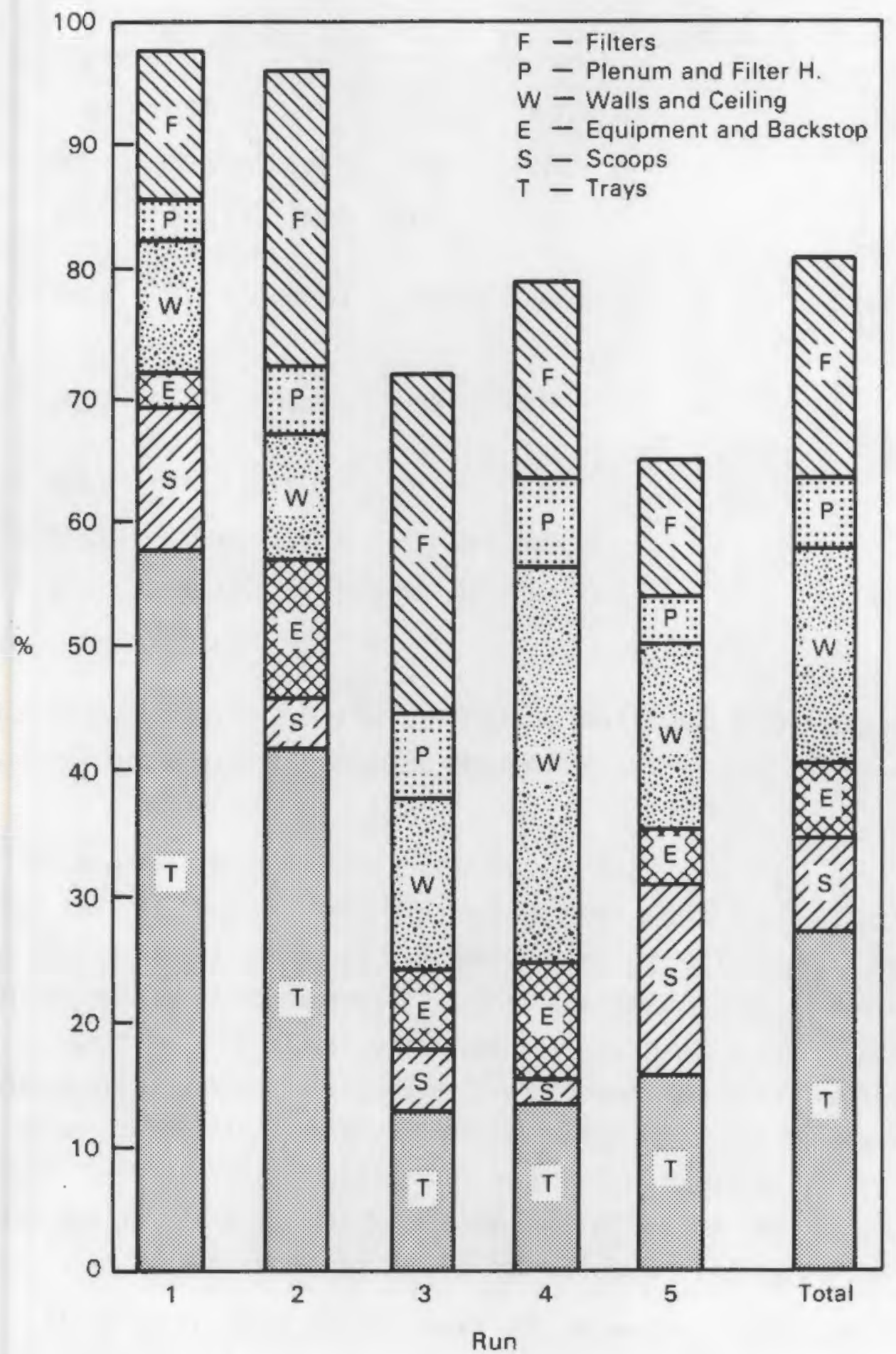

FIGURE 4.1. Percentage of DU Accounted For 
TABLE 4.3. Total Depleted Uranium Accounted For

\begin{tabular}{|c|c|c|c|c|c|c|c|}
\hline \multirow[b]{2}{*}{ Third-Level Area } & \multirow{2}{*}{$\begin{array}{c}\text { Letter } \\
\text { Designation } \\
\end{array}$} & \multicolumn{6}{|c|}{ Grams Per Run } \\
\hline & & $\mathrm{I}$ & 2 & 3 & -4 & 5 & Total \\
\hline Floor, trays & $T$ & 6,798 & 4,929 & 1,711 & 1,822 & 2,091 & 17,351 \\
\hline Floor, scoops & $S$ & 1,312 & 463 & 662 & 198 & 2,049 & 4,684 \\
\hline $\begin{array}{l}\text { Equipment } \\
\text { and backstop }\end{array}$ & $E$ & 333 & 721 & 841 & 1,289 & 582 & 3,766 \\
\hline $\begin{array}{l}\text { Walls, ceiling } \\
\text { baffles, and } \\
\text { tunnel }\end{array}$ & W & 1,236 & 1,746 & 1,805 & 4,173 & 1,945 & 10,904 \\
\hline $\begin{array}{l}\text { Plenum and } \\
\text { filter house }\end{array}$ & p & 379 & 611 & 914 & 941 & 509 & 3,353 \\
\hline Filters & $F$ & 1,377 & 2,777 & 3,539 & 2,049 & 1,436 & 11,174 \\
\hline Total & & 11,435 & 11,247 & 9,472 & 10,471 & 8,612 & 51,232 \\
\hline Projectile weight & & 11,700 & 11,700 & 13,200 & 13,200 & 13,200 & 63,000 \\
\hline
\end{tabular}

run 5. The coded test conditions listed in Table 4.5 may help explain the differences in the patterns of percentage accounted for to those familiar with the codes.

The tray (T) and scoop (S) percentages both represent amounts collected from the floor. The trays accounted for relatively more DU in runs 1 and 2 than in runs 3 to 5 . The smaller percentages for trays and scoops in run 2, compared to run 1, were compensated for by larger percentages for equipment and filters. Runs 1 and 2 used the "E" projectile, and run 2 had target 2 . The three low percent recovery runs ( 3 to 5 ) used the $R$ projectile with targets 1 , 2 , and 3 , respectively. For these six summary areas, filters accounted for the most DU in run 3, walls and ceiling in run 4, and trays in run 5. However, for run 5 , trays, scoops, and walls each accounted for about $15 \%$ of the total projectile weight at $15.8 \%, 15.5 \%$, and $14.7 \%$, respectively.

A more detailed breakdown of the experimental total is given in Table 4.6. (Rounding differences may lead to slightly different totals from 
TABLE 4.4. Percentage of Projectile Weight Accounted For

\begin{tabular}{|c|c|c|c|c|c|c|c|}
\hline \multirow[b]{2}{*}{ Summary Area } & \multirow{2}{*}{$\begin{array}{c}\text { Letter } \\
\text { Designation }\end{array}$} & \multicolumn{3}{|r|}{ Grams } & \multicolumn{3}{|c|}{ Per Run } \\
\hline & & 1 & 2 & 3 & 4 & 5 & Average \\
\hline Tray & T & 58.1 & 42.1 & 13.0 & 13.8 & 15.8 & 27.5 \\
\hline cc & $\mathrm{s}$ & 11 & 4.0 & 5.0 & 1.5 & 15.5 & 7.4 \\
\hline quipment and & & & & & & & \\
\hline $\begin{array}{l}\text { backst op } \\
\text { Walls, ceiling, }\end{array}$ & E & 2.8 & 6.2 & 6.4 & 9.8 & 4.4 & 6.0 \\
\hline $\begin{array}{l}\text { baffles, tunnel } \\
\text { Plenum and } \\
\text { filter house }\end{array}$ & $\begin{array}{l}W \\
P\end{array}$ & $\begin{array}{r}10.6 \\
3.2\end{array}$ & $\begin{array}{r}14.9 \\
5.2\end{array}$ & $\begin{array}{r}13.7 \\
6.9\end{array}$ & $\begin{array}{r}31.6 \\
7.1\end{array}$ & $\begin{array}{r}14.7 \\
3.9\end{array}$ & $\begin{array}{r}17.3 \\
5.3\end{array}$ \\
\hline Filters & $\mathrm{F}$ & 11.8 & 23.7 & 26.8 & 15.5 & 10.9 & 17.7 \\
\hline Total & & 97.7 & 96.1 & 71.8 & 79.3 & 65.2 & 81.3 \\
\hline
\end{tabular}

IABLE 4.5. Test Conditions

Run Shot Target Gun Projectile Velocity

$\begin{array}{lllllll}1 & 1 & 1 & L & E & V\end{array}$

$\begin{array}{lllll}2 & 1 & L & E & S\end{array}$

$\begin{array}{lllll}3 & 1 & L & E & U\end{array}$

$\begin{array}{lllllll}2 & 4 & 2 & L & E & V\end{array}$

$\begin{array}{lllll}5 & 2 & L & E & S\end{array}$

$\begin{array}{lllll}6 & 2 & L & E & U\end{array}$

$\begin{array}{lllllll}3 & 7 & 1 & H & R & S\end{array}$

$\begin{array}{lllll}8 & 1 & H & R & U\end{array}$

$\begin{array}{llllll}9 & 1 & H & \mathrm{R} & M\end{array}$

$\begin{array}{llllll}4 & 10 & 2 & H & R & S\end{array}$

$\begin{array}{lllll}11 & 2 & H & R & U\end{array}$

$\begin{array}{lllll}12 & 2 & H & R & M\end{array}$

$\begin{array}{lllllll}5 & 13 & 3 & H & R & \text { U }\end{array}$

$\begin{array}{lllll}14 & 3 & H & R & M\end{array}$

$\begin{array}{lllll}15 & 3 & H & R & B\end{array}$ 
TABLE 4.6. Summary for Areas and Subareas

\begin{tabular}{|c|c|c|c|c|c|c|}
\hline \multirow[b]{2}{*}{ Second-Level Area } & \multirow[b]{2}{*}{ First-Level Area } & \multirow{2}{*}{$\frac{\text { Total }}{\text { oarea }}$} & \multirow{2}{*}{ DU, $\frac{g}{\text { Area }}$} & \multirow{2}{*}{$\begin{array}{c}\% \\
\text { Accounted } \\
\text { For } \\
\end{array}$} & \multicolumn{2}{|c|}{ Grams/ft ${ }^{2} /$ Round } \\
\hline & & & & & Subarea & Area \\
\hline 1. Floor & 1. Trays & 17,351 & 17,351 & 27.5 & 1.244 & 1.244 \\
\hline 2. Scoops & $\begin{array}{l}\text { 2. Ash } \\
\text { 3. Particles }\end{array}$ & $\begin{array}{r}712 \\
3,973\end{array}$ & 4,685 & 7.4 & $\begin{array}{l}0.051 \\
0.285\end{array}$ & 0.336 \\
\hline 3. Equipment & $\begin{array}{l}\text { 4. Target } \\
\text { 5. X-ray Table } \\
\text { 6. Film Frame }\end{array}$ & $\begin{array}{r}822 \\
39 \\
384\end{array}$ & 1,246 & 2.0 & $\begin{array}{l}0.166 \\
0.092 \\
0.108\end{array}$ & 0.139 \\
\hline 4. Backstop & 7. Backstop & 2,520 & 2,520 & 4.0 & 0.100 & 0.100 \\
\hline 5. Baffles & 13. Baffles & 981 & 981 & .6 & 0.275 & 0.275 \\
\hline 6. Walls \& Celling & $\begin{array}{l}\text { 8. X-ray Wall } \\
\text { 9. Door Wall } \\
\text { 10. Front Wall } \\
\text { 12. Back Wall } \\
\text { 14. Ceiling }\end{array}$ & $\begin{array}{r}2,738 \\
3,511 \\
474 \\
1,704 \\
736\end{array}$ & 9,163 & 14.5 & $\begin{array}{l}0.130 \\
0.083 \\
0.056 \\
0.240 \\
0.038\end{array}$ & 0.093 \\
\hline 7. Tunne1 & 11. Tunnel & 760 & 760 & 1.2 & 0.040 & 0.040 \\
\hline 8. Plenum \& F.H. & $\begin{array}{l}\text { 15. Plenum } \\
\text { 16. Filter House }\end{array}$ & $\begin{array}{r}2,303 \\
396\end{array}$ & 2,699 & 4.3 & $\begin{array}{l}0.126 \\
0.017\end{array}$ & 0.065 \\
\hline 9. Filters & $\begin{array}{l}\text { 18. Prefilter } \\
\text { 19. } 90 \% \\
\text { 20. HEPA }\end{array}$ & $\begin{array}{r}7,785 \\
3,111 \\
278\end{array}$ & 11,174 & 17.7 & $\begin{array}{l}4.905 \\
3.136 \\
0.281\end{array}$ & 3.129 \\
\hline 10. Sweeps & 17. Sweeps & 654 & 654 & 1.0 & 0.016 & 0.016 \\
\hline $\begin{array}{l}\text { Total } \\
\text { Projectile Total } \\
\text { Difference }\end{array}$ & & & $\begin{array}{r}51,233 \\
63,000 \\
-11,767\end{array}$ & $\begin{array}{l}81.3 \\
18.7\end{array}$ & & \\
\hline
\end{tabular}

table to table.) Both the total grams and gram per square foot per round aro tabulated. From Table 4.6 the following points are noted:

- DU tray samples from the floor represented the largest collection

- The weighed particles accounted for most of the grams Du for the scoop samples.

- The backstop accounted for about twice as much DU as the equipment.

- The baffles were added to the back wall and the tunnel to the front wall, and the results for the walls and the total weighted average are shown in Table 4.7 . 
TABLE 4.7. Total and Weighted-Average DU Wall Deposition and Ranking

\begin{tabular}{|c|c|c|c|c|}
\hline \multirow[b]{2}{*}{ Surface } & \multicolumn{2}{|c|}{ Total DU } & \multicolumn{2}{|c|}{ Unit Deposition } \\
\hline & $\mathrm{g}$ & Rank & $\mathrm{gram} / \mathrm{ft}^{2} /$ Round & Rank \\
\hline Door wall & 3,511 & 5 & 0.083 & 3 \\
\hline X-ray wall & 2,738 & 4 & 0.130 & 4 \\
\hline Back wall & 2,685 & 3 & 0.252 & 5 \\
\hline Front wall & 1,234 & 2 & 0.045 & 2 \\
\hline Ceiling & 736 & 1 & $\underline{0.038}$ & 1 \\
\hline Total & 10,904 & & 0.086 & \\
\hline
\end{tabular}

- This wall summary points out the need for considering the weighted average $\mathrm{gram} / \mathrm{ft}^{2} /$ round in determining the areas of highest deposition. Ranking, (with 5 indicating the highest deposition) based on these two variables is also shown in Table 4.7.

- The ranking based on gram $/ \mathrm{ft}^{2} /$ round appears more reasonable given that the projectile and air stream forces are towards the back wall.

- The amount collected by the filters declined progressively with each successive filter stage.

The $\mathrm{gram} / \mathrm{ft}^{2} /$ round results for scoops in Table 4.6 were obtained by dividing the total grams DU by 13,947 , the floor area $(272.6+303.6+353.6)$ times 15 rounds. For the plenum sweeps, the total square feet for the plenum and filter house $(2765.44 \times 15)$ was the divisor.

The most detailed breakdown of the experimental total is in Table 4.8 , which contains the total grams DU [Equation (1)] and the grams/unit/round for each location. The scoop and sweep collection totals are simply divided by 15 in this table to put them on a round basis. The grams/unit/round results from Table 4.8, with scoop and sweep results from Table 4.6, were used in Figure 4.2 to illustrate the deposition distribution. The tendency for deposition to increase from front to back is obyious in the exploded plan view. The fact that most locations follow logical expectations for deposition lends credence to the results. 
TABLE 4.8. Total Grams DU and Grams/ $/ \mathrm{t}^{2} /$ Round for Each Location

\begin{tabular}{|c|c|c|c|}
\hline Sampler & Location & Totai ou, $\mathrm{g}$ & Grams $/ \mathrm{ft}^{2} /$ Round \\
\hline Tray & $\begin{array}{l}\text { I1 Floor-back } \\
12 \text { Floor-mid } \\
13 \text { Floor-front }\end{array}$ & $\begin{array}{l}9,043 \\
3,924 \\
4,483\end{array}$ & $\begin{array}{l}2.212 \\
0.840 \\
0.845\end{array}$ \\
\hline $\begin{array}{l}\text { seoop } \\
(15)\end{array}$ & $\begin{array}{l}41 \text { Ash } \\
41 \text { Particle }\end{array}$ & $\begin{array}{r}712 \\
3,973\end{array}$ & $\begin{array}{r}47.477 \\
264.867\end{array}$ \\
\hline \multirow[t]{13}{*}{ Coupan } & $\begin{array}{l}21 \text { Target } \\
22 \text { T. table-H } \\
23 \text { T. table-V }\end{array}$ & $\begin{array}{l}129 \\
540 \\
153\end{array}$ & $\begin{array}{l}0.429 \\
0.251 \\
0.061\end{array}$ \\
\hline & $\begin{array}{l}24 x \text {-ray table-B } \\
25 x \text {-ray table- } \\
28 \text { x-ray table-T }\end{array}$ & $\begin{array}{r}2 \\
5 \\
31\end{array}$ & $\begin{array}{l}0.014 \\
0.043 \\
0.202\end{array}$ \\
\hline & $\begin{array}{l}26 \text { Film shield-T } \\
27 \text { Film frame } \\
29 \text { Film shleld-O }\end{array}$ & $\begin{array}{r}185 \\
105 \\
94\end{array}$ & $\begin{array}{l}0.014 \\
0.134 \\
0.081\end{array}$ \\
\hline & $\begin{array}{l}31 \text { Bkst.-PPF } \\
33 \text { Bkst.-SPF } \\
34 \text { Bkst.-SPE } \\
35 \text { Bkst.-V } \\
36 \text { Bkst.-H } \\
37 \text { Bkst.-0ther }\end{array}$ & $\begin{array}{r}437 \\
351 \\
41 \\
75 \\
524 \\
\square, 095\end{array}$ & $\begin{array}{l}0.180 \\
0.080 \\
0.012 \\
0.050 \\
0.523 \\
0.089\end{array}$ \\
\hline & $\begin{array}{l}77 \text { Baffles } \\
78 \text { Baffle entry }\end{array}$ & $\begin{array}{l}688 \\
293\end{array}$ & $\begin{array}{l}0.295 \\
0.237\end{array}$ \\
\hline & $\begin{array}{ll}51 & x-\text { ray wall-back } \\
52 & \text { Middle } \\
53 & \text { Front } \\
54 & \text { Opening }\end{array}$ & $\begin{array}{r}1,644 \\
565 \\
429 \\
100\end{array}$ & $\begin{array}{l}0.288 \\
0.099 \\
0.075 \\
0.026\end{array}$ \\
\hline & $\begin{array}{l}\text { 61 Door wall-back } \\
62 \text { Door } \\
63 \text { Front } \\
64 \text { Space-back } \\
65 \text { Space-front }\end{array}$ & $\begin{array}{r}1,607 \\
1,197 \\
249 \\
264 \\
194\end{array}$ & $\begin{array}{l}0.263 \\
0.211 \\
0.041 \\
0.022 \\
0.016\end{array}$ \\
\hline & $\begin{array}{l}71 \text { Front } \\
72 \text { Space }\end{array}$ & $\begin{array}{r}423 \\
51\end{array}$ & $\begin{array}{l}0.055 \\
0.074\end{array}$ \\
\hline & 74 Back woll & 1,704 & 0.240 \\
\hline & $\begin{array}{l}75 \text { Celling-front } \\
76 \text { Celling-back }\end{array}$ & $\begin{array}{l}158 \\
578\end{array}$ & $\begin{array}{l}0.016 \\
0.060\end{array}$ \\
\hline & 73 Tunnet & 760 & 0.040 \\
\hline & $\begin{array}{l}\text { 91 plenuan-floor } \\
\text { a2 plenuan-celling } \\
83 \text { plenum-walls } \\
84 \text { plenum-baffles-1 } \\
85 \text { plenum-baffles-2 } \\
86 \text { pienum-baffles-3 }\end{array}$ & $\begin{array}{l}535 \\
378 \\
433 \\
479 \\
217 \\
216\end{array}$ & $\begin{array}{l}0.177 \\
0.125 \\
0.081 \\
0.159 \\
0.119 \\
0.130\end{array}$ \\
\hline & $\begin{array}{l}91 \text { Filter-house-TA } \\
92 \text { Between 1st, 2nd } \\
93 \text { Between 2nd, HEPA } \\
94 \text { HEPA to fan }\end{array}$ & $\begin{array}{r}275 \\
100 \\
19 \\
3\end{array}$ & $\begin{array}{l}0.066 \\
0.014 \\
0.003 \\
0.001\end{array}$ \\
\hline $\begin{array}{l}\text { Sweeps } \\
(15)\end{array}$ & $\begin{array}{l}81 \text { Plenum-floor } \\
84 \text { pletivm baffles } \\
91 \text { Fileer house-ta } \\
92 \text { Between 1st, 2nd }\end{array}$ & $\begin{array}{r}534 \\
35 \\
61 \\
23\end{array}$ & $\begin{array}{r}35.623 \\
2.367 \\
4.067 \\
1.520\end{array}$ \\
\hline 5itters & $\begin{array}{l}102 \text { Prefilters } \\
3 \text { 907 } \\
4 \text { HEPA }\end{array}$ & $\begin{array}{r}7,785 \\
3,111 \\
278\end{array}$ & $\begin{array}{l}4.905 \\
3.136 \\
0.281\end{array}$ \\
\hline
\end{tabular}




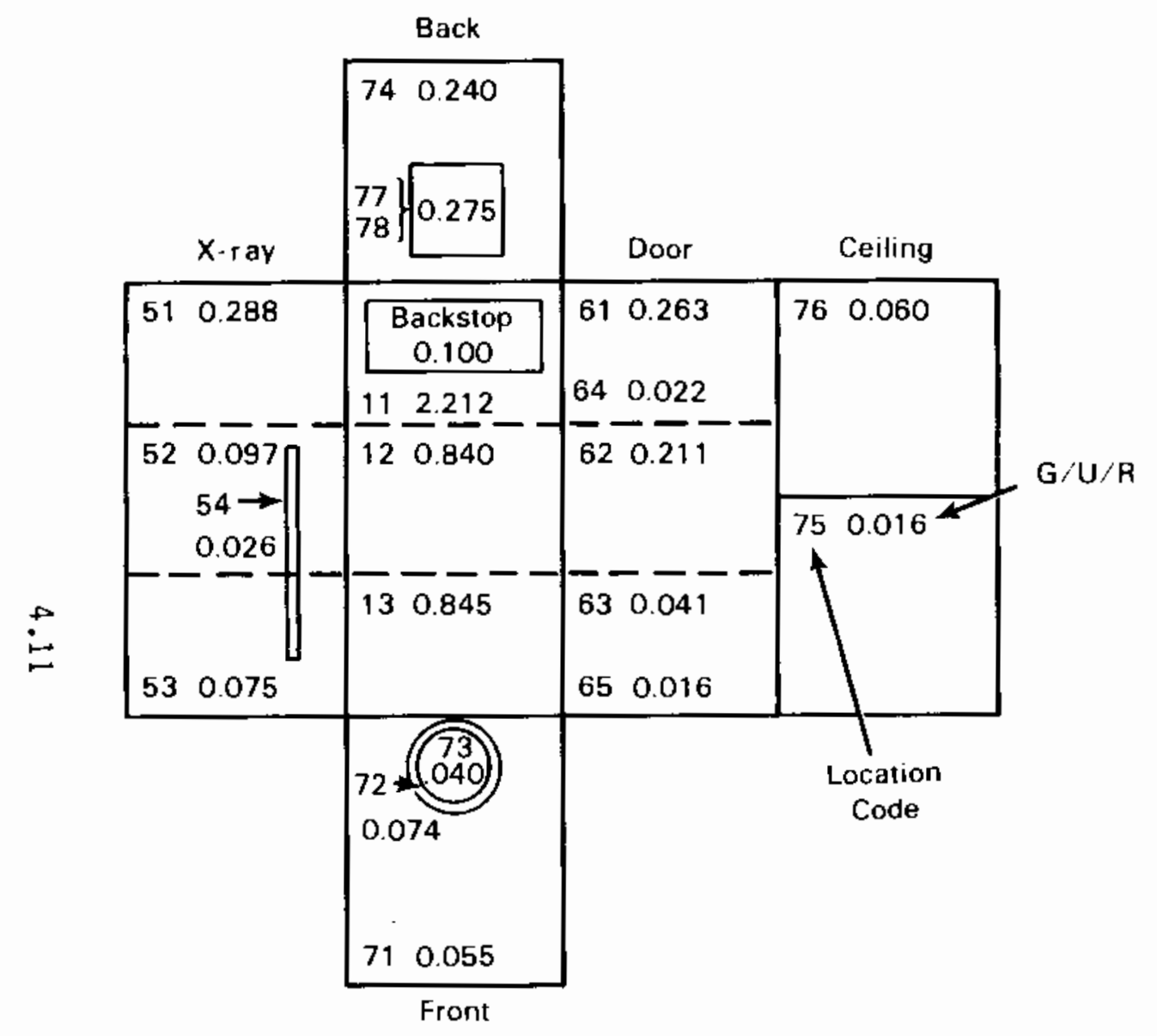

Plenum and Filter House

\begin{tabular}{|c|c|c|}
\hline $\begin{array}{l}\text { 81-86 Plenum } \\
\text { 91-94 Filter House } \\
\text { Sweeps }\end{array}$ & $\begin{array}{l}0.126 \\
0.017 \\
0.016\end{array}$ & \\
\hline \multicolumn{2}{|l|}{ Filters } & \\
\hline $\begin{array}{c}1+2 \text { Pre-F } \\
390 \% \\
4 \text { HEPA }\end{array}$ & $\begin{array}{l}4.905 \\
3.136 \\
0.281\end{array}$ & 3.129 \\
\hline \multicolumn{3}{|c|}{ Scoops From Floor } \\
\hline $\begin{array}{l}\text { 41A Ash } \\
\text { 41P Particles }\end{array}$ & $\begin{array}{l}0.051 \\
0.285\end{array}$ & $\begin{array}{l}0.336 \\
0.139\end{array}$ \\
\hline \multicolumn{3}{|c|}{ Equipment } \\
\hline $\begin{array}{l}\text { 21. Target } \\
\text { 22. T. Table-H } \\
\text { 23. T. Table-V }\end{array}$ & $\begin{array}{l}0.429 \\
0.251 \\
0.061\end{array}$ & 0.166 \\
\hline $\begin{array}{l}\text { 24. X-ray Table-B } \\
\text { 25. X-ray Table-V } \\
\text { 28. X-ray Table-T }\end{array}$ & $\begin{array}{l}0.014 \\
0.043 \\
0.202\end{array}$ & 0.092 \\
\hline $\begin{array}{l}\text { 26. Film Shield-T Side } \\
\text { 27. Film Frame } \\
\text { 29. Film Shield-D Side }\end{array}$ & $\begin{array}{l}0.114 \\
0.134 \\
0.081\end{array}$ & 0.108 \\
\hline
\end{tabular}

FIGURE 4.2. Aggregation of Sampling Locations for Summaries, Grams $/ \mathrm{ft}^{2} /$ Round 


\subsection{PRECISION AND ACCURACY}

The uncertainty associated with an estimated grams DU for an area (GTA) depends on the uncertainty associated with the variables used in its calculation. These variables were defined for Equation (1), except that DU masks the fact that the $\mathrm{mg} / \mathrm{L}$ analytical result is calculated from a more basic analytical result, $\mu \mathrm{g} / \mathrm{L}$, times an analytical dilution, in $\mathrm{mL}$. Then GTA was calculated as

$$
\mathrm{GTA}_{\mathrm{g}}=\left(\frac{\mathrm{SQ} \cdot \mathrm{FT}}{\mathrm{K}}\right)\left(\frac{\mathrm{LEACH}}{\mathrm{NCMP}}\right)\left[(0.001) \mathrm{U}_{\mu} \times \mathrm{DILU}\right]
$$

where, in addition to the variables for Equation (1), $U_{\mu}$ is the $\mu \mathrm{g} / \mathrm{L}$ result from the lifetime fit of analyzed solutions, and DILU is the predilution in $\mathrm{mL}$ of the aliquot taken from the leachate for a (composited) sample.

The standard deviation associated with GTA can be estimated using error propagation procedures. Calculation uses variances, $V$, which are squared standard deviations. The equation for randorn errors is

$$
\begin{gathered}
V_{R}\left(G_{g}\right)=\frac{(G T A)}{(N C M P)^{2}}\left[\frac{V(S Q \cdot F T / K)}{(S Q \cdot F T)^{2}}+\frac{V(L E A C H)}{(L E A C H)^{2}}+\frac{V\left(U_{\mu}\right)}{u_{\mu}^{2}}+\frac{V(D I L U)}{(D I L U)^{2}}\right] \\
=\left(\frac{G T A}{N C M P}\right)^{2}\left[P_{X}^{2}+P_{L}^{2}+P_{\mu}^{2}+P_{D}^{2}\right]
\end{gathered}
$$

where the $\mathrm{P}^{2}$ are relative variances defined implicitly by the terms in the brackets. This approach makes the calculation easier because relative standard deviations can be used (the Ps). The price paid for the easier calculation is an approximate result.

The measurement uncertainties involved are listed in Table 4.9. The upper part of this table lists the preliminary uncertainties for calculating $V_{R}\left(G_{A}\right)$. The lower part lists the uncertainties from the quality control data to be used for checking the reported uncertainties and calculating the variance associated with sampling leachates, bias estimation, and the assignment of 
TABLE 4.9. Measurement Uncertainties

\begin{tabular}{|c|c|c|c|c|c|c|}
\hline \multirow{2}{*}{$\begin{array}{l}\text { Measurement or Calculation } \\
\text { Laser fluorometry }\end{array}$} & \multirow{2}{*}{$\frac{\ln / \mathrm{ts}}{\mathrm{ig} / \mathrm{h}}$} & sd & \multicolumn{3}{|c|}{$\begin{array}{l}\text { Refative sd, } \\
\text { Typical }\end{array}$} & Source of Estimate \\
\hline & & " & $P_{\mu}$ & 3 & & Bushaw (1984) \\
\hline Analytical dilution & m. & $\operatorname{sd}(D)$ & $\mathbf{P}_{\mathrm{D}}$ & 5 & & B. A. Bushar, $1984(a)$ \\
\hline Leach volume & $\mathrm{k}$ & $\operatorname{sd}(L)$ & $P_{L}$ & 0.5 & & Assumed so of $5 \mathrm{~mL}$ and $1 \mathrm{~L}$ \\
\hline Area $\mathrm{ft}^{2}$ & $\mathrm{ft}^{2}$ & $\operatorname{sd}(A)$ & $P_{A}$ & 2 & & Assumed \\
\hline Sampler area & $\mathrm{ft}^{2}$ & $\operatorname{sd}(s)$ & $P_{S}$ & 2 & & Assumed \\
\hline SEXP $=$ Area $/$ Sampler & - & $\operatorname{sd}(x)$ & $P_{x}$ & 2.8 & & $100\left(0.02^{2}+0.02^{2}\right)^{1 / 2}$ \\
\hline DU.Me/L (basic data) & $\mathrm{mg} / \mathrm{L}$ & $\operatorname{sd}\left(u_{m}\right)$ & $P_{M}$ & 5.8 & & $100\left(p_{[}^{2}+p_{X}^{2}+p_{M}^{2}\right)$ \\
\hline Leachant sampling & $m / L$ & (1) & $\left(s_{k}^{2}\right.$ & $\left.-s_{A}^{2}\right)^{1 / 2}$ & 10.4 & Yield standards \\
\hline Leaching b1as & $m g / L$ & (1) & $\begin{array}{l}\text { s } 8 \text {; } \\
\text { sd }\end{array}$ & $y=-4.4$ & & Yteld standards (for $2 \mathrm{~g}$ STND) \\
\hline Analytical bias & $m / L$ & (1) & $\begin{array}{l}\text { Bi } \\
\text { sdín }\end{array}$ & $\begin{array}{l}a s=-5.6 \\
A)=1.53\end{array}$ & & Solution standards (for $1 \mathrm{~g}$ STND) \\
\hline Analytical reproducibility & $\mathbf{m g} / \mathrm{L}$ & (1) & $\begin{array}{l}s_{R} \\
s_{A}\end{array}$ & $\begin{array}{r}12.3 \\
6.5\end{array}$ & & $\begin{array}{l}\text { Fleld replicates } \\
\text { solution standards }\end{array}$ \\
\hline \multicolumn{7}{|l|}{ Assigned values } \\
\hline Yeld standards & $g / g$ & (1) & $S_{g s}$ & 0.39 & & $\begin{array}{l}\text { For base solution only } \\
\text { (hase powiter only) }\end{array}$ \\
\hline Solution standards & $g / L$ & (1) & $s_{s S}$ & 0.13 & & C. M. Matsuzak1, $1983^{\text {(b) }}$ \\
\hline $\begin{array}{l}\text { Cal Ibration standard } \\
\{25.3 \mathrm{~g} / \mathrm{L}\}\end{array}$ & $+9 / L$ & (1) & Rel. & Bias 1.5 & & B. A. Bushaw, $1984^{(\text {a })}$ \\
\hline
\end{tabular}

standard values (sometimes called 'systematic error' to distinguish it from random error). The values listed are based on a preliminary analysis of the quality control data and need further refinement (i.e., more data on the DU oxide powder used in preparation of the yield standards). An equation simflar to Equation (4), with systematic error relative variances, can be used to approximate the systematic error variance $V_{S}\left(G T A_{g}\right)$.

Based on this preliminary look at the precision and accuracy of the measurements, it appears that the random error standard deviation (precision) for GTA will be $6 \%$ to $15 \%$ relative and the systematic error (accuracy) $5 \%$ to $12 \%$ relative. Further work would be needed to refine these estimates. 



\subsection{REFERENCES}

ASHRAE 52-76. 1976. Method of Testing Air Cleaning Used in General Ventilation for Removing Particulate Matter. American Society of Heating, Ventilating, and Air Conditioning Engineers, New York.

ASTM. 1983. "Uranium by Ferrous Sulfate Reduction - Potassium Dichronate Titrimetry." In 1983 Annual Book of ASTM Standards, Nuclear, Solar, and Geothermal Energy, Vol. 12.01. Philadelphia, Pennsylvania.

Burchsted, C. A., A. B. Fuller and J. E. Kahn. 1976. Nuclear Air Cleaning Handbook. EROA-76-21, Oak Ridge National Laboratory, Oak Ridge, Tennessee.

Bushaw, B. A. 1984. "Kinetic Analysis of Laser Induced Phosphorescense in Uranyl Phosphate for Improved Analytical Measurements." In Analytical Spectroscopy, Proceedings of the 26th Conference on Analytical Chemistry in Energy Technology, Knoxville, Tennessee, October 11-13, 1983. Elsevier, New York. 
APPENDIX A

LISTING OF BASIC DATA 
TABLE A.1. Coding for BTD Mass Balance Data Files

\begin{tabular}{|c|c|c|c|}
\hline Field & Name & Code & Information/Comments \\
\hline- & Case & $1-356$ & Sequence number of record on file \\
\hline 1 & RUN & $1-5$ & $\begin{array}{l}\text { A series of } 3 \text { rounds; end of run defined } \\
\text { by changeout of primary prefilters. }\end{array}$ \\
\hline 2 & ROUNDS & $1-15$ & $\begin{array}{l}\text { Total number of rounds fired during } \\
\text { sampler's exposure. }\end{array}$ \\
\hline 3 & FIRST $(a)$ & $1-15$ & $\begin{array}{l}\text { The round number of first shot for the } \\
\text { run. }\end{array}$ \\
\hline 4 & STYPE & $2-6$ & $\begin{array}{l}\text { Type of Sampler } \\
2 \text { Coupon (Ash and Particles) } \\
3 \text { Scoop (Ash } \\
4 \text { Tray } \\
5 \text { Filter } \\
6 \text { Sweep (Plenum and Filter House) }\end{array}$ \\
\hline 5 & LOC & $0-99$ & $\begin{array}{l}\text { Building location represented by sample. } \\
\text { See Table } 2.2 \text { for definition of locations. }\end{array}$ \\
\hline 6 & NCNP & $1-8$ & $\begin{array}{l}\text { Numbers of samplers composited for } \\
\text { analysis. }\end{array}$ \\
\hline 7 & CID & $x \times x \times x x x$ & $\begin{array}{l}\text { Unique ID number for each composite con- } \\
\text { tainer. An initial digit of } 9 \text { implies } \\
\text { a replicate analysis of leached composite } \\
\text { was done. }\end{array}$ \\
\hline 8 & $\mathrm{DU} / \mathrm{MG} / \mathrm{L}$ & $x x x x x x . x x x$ & $\begin{array}{l}\text { The laser/fluorometry analytical result } \\
\text { in milligrams per liter }\end{array}$ \\
\hline 9 & DILU & $x x x x x x$ & $\begin{array}{l}\text { The total dilution factor used to dilute } \\
\text { the leachate for analysis. A "-1" } \\
\text { indicates a weighed DU particle sample. }\end{array}$ \\
\hline 10 & LEACH & $1-8$ & $\begin{array}{l}\text { The liters of leachant used to leach the } \\
\text { sample. Except } 3 \text { means the DU particles } \\
\text { from the scoop samples were weighed (i.e., } \\
\text { not leached). }\end{array}$ \\
\hline 11 & REP & $0-2$ & $\begin{array}{l}\text { Indicator for samples with replicate } \\
\text { analysis } \\
0 \text { No replicate } \\
\text { l First replicate } \\
2 \text { Second replicate }\end{array}$ \\
\hline
\end{tabular}

(a) Not included in listing 
TABLE A.2. Listing of Basic Data

\begin{tabular}{|c|c|c|c|c|c|c|c|c|c|c|}
\hline Case & Stype & LOC & Run & Rounds & NCMP & Cio & DU.MG/L & DILU & LEACH & Rep. \\
\hline $\begin{array}{l}1 \\
2 \\
3 \\
4 \\
5\end{array}$ & $\begin{array}{l}2 . \\
2 \\
2 \\
2 \\
2\end{array}$ & $\begin{array}{l}21 . \\
21 . \\
21 . \\
21 . \\
21 .\end{array}$ & $\begin{array}{l}1 . \\
1 . \\
2 . \\
3 .\end{array}$ & $\begin{array}{l}5 . \\
3 . \\
3 . \\
3 .\end{array}$ & $\begin{array}{l}3 . \\
3 . \\
3 . \\
3 .\end{array}$ & $\begin{array}{r}52 . \\
90052 . \\
211 . \\
974 . \\
90194 .\end{array}$ & $\begin{array}{r}171.372 \\
185.073 \\
137.223 \\
95.250 \\
70.133\end{array}$ & $\begin{array}{r}2636.0 \\
1501.0 \\
331.0 \\
533.0 \\
503.0\end{array}$ & $\begin{array}{l}1 . \\
1: \\
1: \\
1:\end{array}$ & $\begin{array}{l}1 . \\
2: \\
0 . \\
2 .\end{array}$ \\
\hline $\begin{array}{r}6 \\
7 \\
8 \\
8 \\
10\end{array}$ & $\begin{array}{l}2 . \\
2 . \\
2 . \\
2 .\end{array}$ & $\begin{array}{l}21 . \\
21 . \\
21 . \\
22 . \\
22 .\end{array}$ & $\begin{array}{l}5 . \\
5 . \\
5 . \\
10 \\
2 .\end{array}$ & $\begin{array}{l}1 . \\
1: \\
3 .\end{array}$ & $\begin{array}{l}3 . \\
1: \\
\text { s. } \\
4 .\end{array}$ & $\begin{array}{r}155 . \\
276 . \\
90276 . \\
54 . \\
154 .\end{array}$ & $\begin{array}{r}41.550 \\
1.720 \\
0.760 \\
30.332 \\
259.680\end{array}$ & $\begin{array}{l}503.0 \\
253.5 \\
253.5 \\
401.0 \\
439.0\end{array}$ & $\begin{array}{l}3: \\
1: \\
1:\end{array}$ & $\begin{array}{l}0 . \\
1 . \\
2 . \\
0 . \\
0 .\end{array}$ \\
\hline $\begin{array}{l}11 \\
12 \\
13 \\
14 \\
15\end{array}$ & $\begin{array}{l}2 . \\
2 . \\
2 . \\
2 .\end{array}$ & $\begin{array}{l}22 . \\
22 . \\
22 . \\
23 . \\
23 .\end{array}$ & $\begin{array}{l}3 . \\
5: \\
1: \\
1 .\end{array}$ & $\begin{array}{l}3 . \\
3 . \\
3 . \\
3 .\end{array}$ & $\begin{array}{l}2 . \\
5 . \\
6 . \\
3 . \\
3 .\end{array}$ & $\begin{array}{r}137 . \\
254 . \\
299 . \\
136 . \\
70136 .\end{array}$ & $\begin{array}{r}12.179 \\
351.700 \\
116.140 \\
9.373 \\
11.356\end{array}$ & $\begin{array}{r}503.0 \\
25653.0 \\
533.0 \\
101.0 \\
501.0\end{array}$ & $\begin{array}{l}1: \\
i: \\
1:\end{array}$ & $\begin{array}{l}0 . \\
0 . \\
0 . \\
1 . \\
2 .\end{array}$ \\
\hline $\begin{array}{l}16 \\
17 \\
18 \\
19 \\
20\end{array}$ & $\begin{array}{l}2 . \\
2 . \\
2 . \\
2 .\end{array}$ & $\begin{array}{l}23 . \\
23 . \\
23 . \\
23 . \\
24 .\end{array}$ & $\begin{array}{l}2 . \\
3 . \\
4 . \\
5 . \\
1 .\end{array}$ & $\begin{array}{l}3 . \\
3 . \\
3 .\end{array}$ & $\begin{array}{l}2 . \\
1 . \\
3 . \\
2 .\end{array}$ & $\begin{array}{l}133 . \\
237 . \\
251 . \\
275 . \\
55 .\end{array}$ & $\begin{array}{r}15.350 \\
9.480 \\
16.620 \\
26.850 \\
1.537\end{array}$ & $\begin{array}{l}201.0 \\
503.0 \\
503.0 \\
533.0 \\
101.0\end{array}$ & $\begin{array}{l}1 . \\
1: \\
1 . \\
1.0\end{array}$ & $\begin{array}{l}0 . \\
0 . \\
0 . \\
0 . \\
0 .\end{array}$ \\
\hline $\begin{array}{l}21 \\
22 \\
23 \\
24 \\
25\end{array}$ & $\begin{array}{l}2 . \\
20 \\
2 . \\
2 .\end{array}$ & $\begin{array}{l}26 . \\
24 . \\
24 . \\
25 . \\
25 .\end{array}$ & $\begin{array}{l}2 . \\
3 . \\
1 . \\
2 .\end{array}$ & $\begin{array}{l}3 . \\
3 . \\
3 . \\
3 . \\
3 .\end{array}$ & $\begin{array}{l}1 . \\
1: \\
2: \\
2 .\end{array}$ & $\begin{array}{r}144 . \\
170 . \\
248 . \\
58 . \\
150 .\end{array}$ & $\begin{array}{r}3.875 \\
1.660 \\
4.130 \\
6.164 \\
10.410\end{array}$ & $\begin{array}{r}2.5 \\
503.0 \\
503.0 \\
101.0 \\
201.0\end{array}$ & $\begin{array}{l}\because: \\
1: \\
1:\end{array}$ & $\begin{array}{l}0 . \\
0 . \\
0 . \\
0 . \\
0 .\end{array}$ \\
\hline $\begin{array}{l}26 \\
27 \\
28 \\
29 \\
30\end{array}$ & $\begin{array}{l}2 . \\
? . \\
2 . \\
2 .\end{array}$ & $\begin{array}{l}25 . \\
25 . \\
26 . \\
26 . \\
26 .\end{array}$ & $\begin{array}{l}3 . \\
4 . \\
10 \\
2 . \\
3 .\end{array}$ & $\begin{array}{l}3 . \\
3 . \\
3 . \\
3 .\end{array}$ & $\begin{array}{l}2 . \\
1 . \\
5 . \\
3 .\end{array}$ & $\begin{array}{l}191 . \\
250 . \\
54 . \\
130 . \\
190 .\end{array}$ & $\begin{array}{r}5.190 \\
12.210 \\
51.272 \\
59.940 \\
28.290\end{array}$ & $\begin{array}{l}503.0 \\
503.0 \\
601.0 \\
201.0 \\
503.0\end{array}$ & $\begin{array}{l}1: \\
1:\end{array}$ & $\begin{array}{l}0 . \\
0 . \\
0 . \\
0 . \\
0 .\end{array}$ \\
\hline $\begin{array}{l}31 \\
32 \\
33 \\
34 \\
35\end{array}$ & $\begin{array}{l}2 . \\
2 . \\
2 . \\
2 . \\
2 .\end{array}$ & $\begin{array}{l}26 . \\
26 . \\
26 . \\
27 . \\
27 .\end{array}$ & $\begin{array}{l}4: \\
4: \\
10 \\
2 .\end{array}$ & $\begin{array}{l}3 . \\
3 . \\
3 . \\
3 .\end{array}$ & $\begin{array}{l}5 . \\
5 . \\
4 . \\
4 .\end{array}$ & $\begin{array}{r}252 . \\
90232 . \\
273 . \\
73 . \\
111 .\end{array}$ & $\begin{array}{r}233.853 \\
252.840 \\
25.085 \\
39.064 \\
32.330\end{array}$ & $\begin{array}{r}25653.0 \\
25553.0 \\
503.0 \\
4031.0 \\
431.0\end{array}$ & $\begin{array}{l}1 . \\
1 . \\
1 . \\
1 .\end{array}$ & $\begin{array}{l}1 . \\
2 . \\
0 . \\
0 . \\
0 .\end{array}$ \\
\hline $\begin{array}{l}36 \\
37 \\
38 \\
39 \\
40\end{array}$ & $\begin{array}{l}2 . \\
2 . \\
2 . \\
2 .\end{array}$ & $\begin{array}{l}27 . \\
27 . \\
28 . \\
28 . \\
28 .\end{array}$ & $\begin{array}{l}4 . \\
5 . \\
5 . \\
2 . \\
3 .\end{array}$ & $\begin{array}{l}3 . \\
3 . \\
3 .\end{array}$ & $\begin{array}{l}3 . \\
40 \\
2 . \\
2 .\end{array}$ & $\begin{array}{l}246 . \\
235 . \\
31 . \\
119 . \\
188 .\end{array}$ & $\begin{array}{r}133.783 \\
32.780 \\
31.637 \\
64.073 \\
53.310\end{array}$ & $\begin{array}{r}25653.0 \\
503.0 \\
431.0 \\
231.0 \\
503.0\end{array}$ & $\begin{array}{l}1: \\
1: \\
1 . \\
1 .\end{array}$ & $\begin{array}{l}0 . \\
0 . \\
0 . \\
0 . \\
0 .\end{array}$ \\
\hline $\begin{array}{l}41 \\
42 \\
43 \\
44 \\
45\end{array}$ & $\begin{array}{l}2 . \\
2 . \\
2 . \\
2 .\end{array}$ & $\begin{array}{l}28 . \\
28 . \\
29 . \\
29 . \\
29 .\end{array}$ & $\begin{array}{l}4 . \\
5: \\
1: \\
2: \\
2 .\end{array}$ & $\begin{array}{l}3 . \\
3: \\
3 . \\
3 .\end{array}$ & $\begin{array}{l}2: \\
1: \\
5: \\
4 .\end{array}$ & $\begin{array}{r}249 . \\
288 . \\
36 . \\
116 . \\
90116 .\end{array}$ & $\begin{array}{l}39.130 \\
13.800 \\
37.918 \\
16.310 \\
15.700\end{array}$ & $\begin{array}{r}503.0 \\
535.0 \\
1031.0 \\
201.0 \\
231.0\end{array}$ & $\begin{array}{l}1: \\
1: \\
1:\end{array}$ & $\begin{array}{l}0 . \\
0 . \\
0 . \\
1 . \\
2 .\end{array}$ \\
\hline
\end{tabular}


TABLE A.2. (contd)

\begin{tabular}{|c|c|c|c|c|c|c|c|c|c|c|}
\hline Case & Stype & Loc & Run & Rounds & KCMP & CID & DU. $1 \mathrm{ES} / \mathrm{L}$ & DILU] & LEACH & Rep \\
\hline $\begin{array}{l}46 \\
47 \\
48 \\
49 \\
50\end{array}$ & $\begin{array}{l}2 . \\
2 . \\
2 . \\
2 .\end{array}$ & $\begin{array}{l}29 . \\
29 . \\
31 . \\
31: \\
31 .\end{array}$ & $\begin{array}{l}3 . \\
4 . \\
3: \\
3 .\end{array}$ & $\begin{array}{l}3: \\
3: \\
3:\end{array}$ & $\begin{array}{l}5 . \\
5 . \\
4 . \\
4 .\end{array}$ & $\begin{array}{l}179 . \\
247 . \\
100 . \\
152 . \\
215 .\end{array}$ & $\begin{array}{r}9.440 \\
137.570 \\
17.930 \\
155.050 \\
21.190\end{array}$ & $\begin{array}{r}533.0 \\
25053.0 \\
1031.0 \\
231.0 \\
503.0\end{array}$ & $\begin{array}{l}1: \\
1: \\
1: \\
1 .\end{array}$ & $\begin{array}{l}0 . \\
0 . \\
0 . \\
0 . \\
0 .\end{array}$ \\
\hline $\begin{array}{l}51 \\
52 \\
53 \\
54 \\
55\end{array}$ & $\begin{array}{l}2 . \\
2: \\
2 . \\
2 .\end{array}$ & $\begin{array}{l}31 . \\
31 . \\
33 . \\
33 . \\
33 .\end{array}$ & $\begin{array}{l}4 . \\
5 . \\
1 . \\
3 .\end{array}$ & $\begin{array}{l}3 . \\
3 . \\
3 . \\
3 .\end{array}$ & $\begin{array}{l}4 . \\
4 . \\
4 .\end{array}$ & $\begin{array}{r}254 . \\
272 . \\
71 . \\
113 . \\
236 .\end{array}$ & $\begin{array}{r}158.180 \\
77.460 \\
30.175 \\
26.630 \\
31.870\end{array}$ & $\begin{array}{l}503.0 \\
503.0 \\
501.0 \\
201.0 \\
503.0\end{array}$ & $\begin{array}{l}1: \\
1: \\
1:\end{array}$ & $\begin{array}{l}0 . \\
0 . \\
0 . \\
0 . \\
0 .\end{array}$ \\
\hline $\begin{array}{l}56 \\
57 \\
58 \\
59 \\
60\end{array}$ & $\begin{array}{l}2 . \\
2 . \\
2 . \\
2 . \\
2 .\end{array}$ & $\begin{array}{l}33 . \\
33 . \\
34 . \\
34 . \\
34 .\end{array}$ & $\begin{array}{l}4 . \\
5 . \\
1 . \\
2 . \\
4 .\end{array}$ & $\begin{array}{l}3 . \\
3 . \\
3 . \\
3 .\end{array}$ & $\begin{array}{l}4 . \\
4 . \\
4 . \\
4 .\end{array}$ & $\begin{array}{l}255 . \\
310 . \\
132 . \\
129 . \\
255 .\end{array}$ & $\begin{array}{r}95.510 \\
25.690 \\
1.719 \\
2.620 \\
17.960\end{array}$ & $\begin{array}{r}25653.0 \\
503.0 \\
151.0 \\
201.0 \\
503.0\end{array}$ & $\begin{array}{l}1: \\
1: \\
1 .\end{array}$ & $\begin{array}{l}0 . \\
0 . \\
0 . \\
0 . \\
0 .\end{array}$ \\
\hline $\begin{array}{l}61 \\
62 \\
63 \\
64 \\
65\end{array}$ & $\begin{array}{l}2 . \\
2 . \\
2 . \\
2 .\end{array}$ & $\begin{array}{l}34 . \\
35 . \\
35 . \\
35 . \\
35 .\end{array}$ & $\begin{array}{l}5 . \\
1 . \\
2 . \\
3 . \\
4 .\end{array}$ & $\begin{array}{l}3 . \\
3 \\
3 \\
3\end{array}$ & $\begin{array}{l}4 . \\
4 . \\
4 .\end{array}$ & $\begin{array}{l}375 . \\
51 . \\
132 . \\
175 . \\
253 .\end{array}$ & $\begin{array}{r}2.310 \\
7.090 \\
22.420 \\
25.400 \\
38.990\end{array}$ & $\begin{array}{l}503.0 \\
431.0 \\
201.0 \\
503.0 \\
503.0\end{array}$ & $\begin{array}{l}1: \\
1: \\
1: \\
1 .\end{array}$ & $\begin{array}{l}0 . \\
0 . \\
0 . \\
0 . \\
0 .\end{array}$ \\
\hline $\begin{array}{l}66 \\
57 \\
68 \\
69 \\
70\end{array}$ & $\begin{array}{l}2 . \\
2 . \\
2: \\
2 .\end{array}$ & $\begin{array}{l}35 . \\
35 . \\
36 . \\
36 . \\
36 .\end{array}$ & $\begin{array}{l}5 . \\
1 . \\
2 . \\
3 . \\
4 .\end{array}$ & $\begin{array}{l}3 . \\
3 . \\
3 . \\
3 .\end{array}$ & $\begin{array}{l}3 . \\
3 . \\
2 . \\
2 .\end{array}$ & $\begin{array}{l}323 . \\
53 . \\
121 . \\
173 . \\
259 .\end{array}$ & $\begin{array}{r}9.470 \\
30.569 \\
59.790 \\
170.423 \\
156.950\end{array}$ & $\begin{array}{r}593.0 \\
2010.0 \\
291.0 \\
503.0 \\
25353.0\end{array}$ & $\begin{array}{l}i: \\
i:\end{array}$ & $\begin{array}{l}0 . \\
0 . \\
0 . \\
0 . \\
0 .\end{array}$ \\
\hline $\begin{array}{l}71 \\
72 \\
73 \\
76 \\
75\end{array}$ & $\begin{array}{l}2 . \\
2 . \\
2 . \\
2 . \\
2 .\end{array}$ & $\begin{array}{l}36 . \\
36 . \\
37 . \\
37 \\
37 .\end{array}$ & $\begin{array}{l}5 . \\
5 . \\
1 . \\
2 . \\
3 .\end{array}$ & $\begin{array}{l}3 . \\
3 . \\
3 . \\
3 .\end{array}$ & $\begin{array}{l}4 . \\
4 . \\
5 . \\
5 .\end{array}$ & $\begin{array}{r}331 . \\
90331 . \\
135 . \\
115 . \\
175 .\end{array}$ & $\begin{array}{r}482.410 \\
459.510 \\
36.563 \\
26.870 \\
134.670\end{array}$ & $\begin{array}{r}5533.0 \\
5533.0 \\
1001.0 \\
209.0 \\
503.0\end{array}$ & $\begin{array}{l}1: \\
1: \\
1: \\
1 .\end{array}$ & $\begin{array}{l}1 . \\
0 . \\
0 . \\
0 .\end{array}$ \\
\hline $\begin{array}{l}76 \\
77 \\
78 \\
79 \\
30\end{array}$ & $\begin{array}{l}2 . \\
2 . \\
3 . \\
2 . \\
2 .\end{array}$ & $\begin{array}{l}37 . \\
37 . \\
51 . \\
51 . \\
51 .\end{array}$ & $\begin{array}{l}4 . \\
5 . \\
1 . \\
2 . \\
3 .\end{array}$ & $\begin{array}{l}3 . \\
3 . \\
3 . \\
3 .\end{array}$ & $\begin{array}{l}3 . \\
3 . \\
4 . \\
4 . \\
4 .\end{array}$ & $\begin{array}{r}252 . \\
278 . \\
88 . \\
133 . \\
214 .\end{array}$ & $\begin{array}{r}113.433 \\
58.760 \\
97.507 \\
77.133 \\
92.770\end{array}$ & $\begin{array}{r}503.0 \\
503.0 \\
1001.0 \\
401.0 \\
503.0\end{array}$ & $\begin{array}{l}1 . \\
1 . \\
1 . \\
1 .\end{array}$ & $\begin{array}{l}0 . \\
0 . \\
0 . \\
0 . \\
0 .\end{array}$ \\
\hline $\begin{array}{l}31 \\
82 \\
83 \\
84 \\
85\end{array}$ & $\begin{array}{l}2 . \\
2 . \\
2 . \\
2 . \\
2 .\end{array}$ & $\begin{array}{l}51 . \\
51 . \\
52 . \\
52 . \\
52 .\end{array}$ & $\begin{array}{l}4 . \\
5: \\
1: \\
2 . \\
3 .\end{array}$ & $\begin{array}{l}3 . \\
3 . \\
3 . \\
3 .\end{array}$ & $\begin{array}{l}4 . \\
4 . \\
4 . \\
4 .\end{array}$ & $\begin{array}{l}258 . \\
337 . \\
32 . \\
122 . \\
234 .\end{array}$ & $\begin{array}{r}251.150 \\
239.280 \\
55.397 \\
48.910 \\
33.120\end{array}$ & $\begin{array}{r}2583.0 \\
10533.0 \\
401.0 \\
201.0 \\
503.0\end{array}$ & $\begin{array}{l}1: \\
1: \\
1:\end{array}$ & $\begin{array}{l}0 . \\
0 . \\
0 . \\
0 . \\
0 .\end{array}$ \\
\hline $\begin{array}{l}36 \\
87 \\
88 \\
89 \\
90\end{array}$ & $\begin{array}{l}2 . \\
2 . \\
2 . \\
2 .\end{array}$ & $\begin{array}{l}52 . \\
52 . \\
53 . \\
53 . \\
53 .\end{array}$ & $\begin{array}{l}4 . \\
5 . \\
1 . \\
2 . \\
3 .\end{array}$ & $\begin{array}{l}3 . \\
3 . \\
3 . \\
3 .\end{array}$ & $\begin{array}{l}5 . \\
4.5 \\
6 . \\
4 .\end{array}$ & $\begin{array}{r}250 . \\
339 . \\
96 . \\
167 . \\
233 .\end{array}$ & $\begin{array}{r}130.120 \\
42.030 \\
14.141 \\
37.050 \\
34.470\end{array}$ & $\begin{array}{r}25653.0 \\
553.0 \\
251.0 \\
401.0 \\
503.0\end{array}$ & $\begin{array}{l}1: \\
1: \\
1:\end{array}$ & $\begin{array}{l}0 . \\
0 . \\
0 . \\
0 . \\
0 .\end{array}$ \\
\hline
\end{tabular}


IABLE A.2. (contd)

\begin{tabular}{|c|c|c|c|c|c|c|c|c|c|c|}
\hline Case & Stype & Loc & $\underline{\text { Run }}$ & Rounds & MCAP & Cio & DU.MG/L & DILU & LEACH & Rep \\
\hline $\begin{array}{l}91 \\
72 \\
93 \\
74 \\
95\end{array}$ & $\begin{array}{l}2 . \\
2 . \\
2 . \\
2 .\end{array}$ & $\begin{array}{l}53 . \\
53 . \\
54 . \\
54 . \\
54 .\end{array}$ & $\begin{array}{l}4 . \\
5 . \\
1 . \\
2 .\end{array}$ & $\begin{array}{l}3 . \\
3: \\
3: \\
3 .\end{array}$ & $\begin{array}{l}4 . \\
4 . \\
2 . \\
2 . \\
2 .\end{array}$ & $\begin{array}{r}257 . \\
336 . \\
39 . \\
134 . \\
90134 .\end{array}$ & $\begin{array}{r}75.530 \\
14.500 \\
1.305 \\
5.023 \\
5.290\end{array}$ & $\begin{array}{r}25653.0 \\
503.0 \\
101.0 \\
201.0 \\
201.0\end{array}$ & $\begin{array}{l}1: \\
1: \\
1: \\
1:\end{array}$ & $\begin{array}{l}0 . \\
0 . \\
0 . \\
1 . \\
2 .\end{array}$ \\
\hline $\begin{array}{r}96 \\
97 \\
98 \\
99 \\
100\end{array}$ & $\begin{array}{l}2 . \\
2 . \\
2 . \\
2 .\end{array}$ & $\begin{array}{l}54 . \\
54 . \\
54 . \\
54 . \\
51 .\end{array}$ & $\begin{array}{l}3 . \\
3 . \\
4: \\
5 .\end{array}$ & $\begin{array}{l}3 . \\
3 . \\
3 . \\
3 .\end{array}$ & $\begin{array}{l}i: \\
1: \\
2: \\
2:\end{array}$ & $\begin{array}{r}178 . \\
90178 . \\
243 . \\
271 . \\
78 .\end{array}$ & $\begin{array}{r}5.430 \\
5.460 \\
15.280 \\
0.060 \\
138.407\end{array}$ & $\begin{array}{r}503.0 \\
503.0 \\
503.0 \\
120.0 \\
2510.0\end{array}$ & $\begin{array}{l}1 . \\
\vdots: \\
1:\end{array}$ & $\begin{array}{l}1 . \\
2 . \\
0 . \\
0 . \\
0 .\end{array}$ \\
\hline $\begin{array}{l}101 \\
102 \\
103 \\
104 \\
105\end{array}$ & $\begin{array}{l}2 . \\
2 . \\
2 . \\
2 .\end{array}$ & $\begin{array}{l}61 . \\
61 . \\
61 . \\
61 . \\
61 .\end{array}$ & $\begin{array}{l}2 . \\
3 . \\
50 \\
50\end{array}$ & $\begin{array}{l}3 . \\
3 . \\
3 . \\
3 . \\
3 .\end{array}$ & $\begin{array}{l}4 . \\
4 . \\
4 . \\
2 .\end{array}$ & $\begin{array}{r}125 . \\
213 . \\
90213 . \\
271 . \\
277 .\end{array}$ & $\begin{array}{r}105.480 \\
125.670 \\
106.050 \\
303.310 \\
30.370\end{array}$ & $\begin{array}{r}231.0 \\
503.0 \\
10553.0 \\
503.0 \\
533.0\end{array}$ & $\begin{array}{l}1 . \\
1: \\
1:\end{array}$ & $\begin{array}{l}0 . \\
1 . \\
2 . \\
0 . \\
0 .\end{array}$ \\
\hline $\begin{array}{l}196 \\
107 \\
108 \\
109 \\
110\end{array}$ & $\begin{array}{l}2 . \\
2 . \\
2 . \\
2 . \\
2 .\end{array}$ & $\begin{array}{l}62 . \\
62 . \\
62 . \\
62 . \\
62 .\end{array}$ & $\begin{array}{l}1 . \\
2: \\
3 . \\
5:\end{array}$ & $\begin{array}{l}3 . \\
3 . \\
3 . \\
3 .\end{array}$ & $\begin{array}{l}4 . \\
4 . \\
4 . \\
4 .\end{array}$ & $\begin{array}{l}77 . \\
126 . \\
139 . \\
253 . \\
332 .\end{array}$ & $\begin{array}{r}16.272 \\
232.260 \\
62.290 \\
131.890 \\
143.400\end{array}$ & $\begin{array}{l}251.0 \\
531.0 \\
503.0 \\
503.0 \\
503.0\end{array}$ & i: & $\begin{array}{l}0 . \\
0 . \\
0 . \\
0 . \\
0 .\end{array}$ \\
\hline $\begin{array}{l}111 \\
112 \\
115 \\
114 \\
115\end{array}$ & $\begin{array}{l}2 . \\
2 . \\
2 . \\
2 . \\
2 .\end{array}$ & $\begin{array}{l}63 . \\
63 . \\
63 . \\
63 . \\
63 .\end{array}$ & $\begin{array}{l}1 . \\
2 . \\
3 . \\
3 .\end{array}$ & $\begin{array}{l}3 . \\
3 . \\
3 .\end{array}$ & $\begin{array}{l}4 . \\
4 . \\
4: \\
4 .\end{array}$ & $\begin{array}{r}75 . \\
114 . \\
238 . \\
90238 . \\
270 .\end{array}$ & $\begin{array}{r}6.388 \\
21.293 \\
33.950 \\
35.039 \\
29.300\end{array}$ & $\begin{array}{l}109.0 \\
201.0 \\
503.0 \\
503.0 \\
503.0\end{array}$ & $\begin{array}{l}1: \\
1:\end{array}$ & $\begin{array}{l}0 . \\
0 . \\
1 . \\
2 . \\
0 .\end{array}$ \\
\hline $\begin{array}{l}116 \\
117 \\
118 \\
119 \\
120\end{array}$ & $\begin{array}{l}2 . \\
2 . \\
2 . \\
2 .\end{array}$ & $\begin{array}{l}63 . \\
64 . \\
64 . \\
64 . \\
64 .\end{array}$ & $\begin{array}{l}5 . \\
1 . \\
2 . \\
3 . \\
4 .\end{array}$ & $\begin{array}{l}3 . \\
3 . \\
3 . \\
3 .\end{array}$ & $\begin{array}{l}4: \\
2: \\
2: \\
2: \\
2 .\end{array}$ & $\begin{array}{r}300 . \\
37 . \\
120 . \\
239 . \\
262 .\end{array}$ & $\begin{array}{r}16.700 \\
2.868 \\
5.600 \\
3.890 \\
11.243\end{array}$ & $\begin{array}{l}503.0 \\
+01.0 \\
231.0 \\
503.0 \\
503.0\end{array}$ & $\begin{array}{l}1: \\
1: \\
1:\end{array}$ & $\begin{array}{l}0 . \\
0 . \\
0 . \\
0 . \\
0 .\end{array}$ \\
\hline $\begin{array}{l}121 \\
122 \\
123 \\
126 \\
125\end{array}$ & $\begin{array}{l}2 . \\
2 . \\
2 . \\
2 . \\
2 .\end{array}$ & $\begin{array}{l}64 . \\
65 . \\
65 . \\
65 . \\
65 .\end{array}$ & $\begin{array}{l}5 . \\
1: \\
2 . \\
3 . \\
4 .\end{array}$ & $\begin{array}{l}3 . \\
3 . \\
3 . \\
3 .\end{array}$ & $\begin{array}{l}2 . \\
2 . \\
2: \\
2 .\end{array}$ & $\begin{array}{r}270 . \\
79 . \\
128 . \\
210 . \\
241 .\end{array}$ & $\begin{array}{r}4.820 \\
3.707 \\
1.900 \\
2.460 \\
13.910\end{array}$ & $\begin{array}{r}503.0 \\
26.0 \\
2.5 \\
503.0 \\
503.0\end{array}$ & $\begin{array}{l}1: \\
1 . \\
1 . \\
7 .\end{array}$ & $\begin{array}{l}0 . \\
0 . \\
0 . \\
0 . \\
0 .\end{array}$ \\
\hline $\begin{array}{l}126 \\
127 \\
128 \\
129 \\
130\end{array}$ & $\begin{array}{l}2 . \\
2 . \\
2 . \\
2 . \\
2 .\end{array}$ & $\begin{array}{l}65 . \\
71 . \\
71 . \\
71 . \\
71 .\end{array}$ & $\begin{array}{l}5 . \\
1 . \\
2 . \\
3 . \\
4 .\end{array}$ & $\begin{array}{l}3 . \\
3 . \\
3 . \\
3 .\end{array}$ & $\begin{array}{l}2 . \\
5: \\
5 . \\
6 . \\
5 .\end{array}$ & $\begin{array}{r}236 . \\
70 . \\
127 . \\
231 . \\
259 .\end{array}$ & $\begin{array}{r}1.910 \\
33.737 \\
43.715 \\
54.405 \\
51.320\end{array}$ & $\begin{array}{l}120.0 \\
504.0 \\
431.0 \\
503.0 \\
503.0\end{array}$ & $\begin{array}{l}1 . \\
1: \\
i: \\
1 .\end{array}$ & $\begin{array}{l}? . \\
0 . \\
0 . \\
0 .\end{array}$ \\
\hline $\begin{array}{l}139 \\
132 \\
133 \\
136 \\
135\end{array}$ & $\begin{array}{l}2 . \\
2 . \\
2 . \\
2 .\end{array}$ & $\begin{array}{l}71 . \\
71 . \\
72 . \\
72 . \\
72 .\end{array}$ & $\begin{array}{l}5 . \\
5: \\
1: \\
3:\end{array}$ & $\begin{array}{l}3 . \\
3 . \\
3 . \\
3 .\end{array}$ & $\begin{array}{l}3 . \\
5: \\
2: \\
2 . \\
2 .\end{array}$ & $\begin{array}{r}338 . \\
90378 . \\
74 . \\
130 . \\
276 .\end{array}$ & $\begin{array}{r}23.620 \\
25.473 \\
5.015 \\
23.810 \\
21.590\end{array}$ & $\begin{array}{l}503.0 \\
503.0 \\
131.0 \\
401.0 \\
503.0\end{array}$ & $\begin{array}{l}1: \\
1: \\
1: \\
1:\end{array}$ & $\begin{array}{l}1 . \\
2 . \\
0 . \\
0 . \\
0 .\end{array}$ \\
\hline
\end{tabular}


TABLE A.2. (contd)

\begin{tabular}{|c|c|c|c|c|c|c|c|c|c|c|}
\hline Case & Stype & LoC & Run & Rounds & MCMP & CID & DU.MG/L & DILU & LEACH & Rep \\
\hline $\begin{array}{l}136 \\
137 \\
138 \\
139 \\
140\end{array}$ & $\begin{array}{l}2 . \\
2 . \\
2 . \\
2 . \\
2 .\end{array}$ & $\begin{array}{l}72 . \\
72 . \\
73 . \\
73 . \\
73 .\end{array}$ & $\begin{array}{l}4 . \\
5 . \\
1 . \\
2 .\end{array}$ & $\begin{array}{l}3 . \\
3 . \\
3 .\end{array}$ & $\begin{array}{l}2 . \\
2 . \\
5 . \\
5 .\end{array}$ & $\begin{array}{r}244 . \\
239 . \\
35 . \\
135 . \\
212 .\end{array}$ & $\begin{array}{r}23.420 \\
22.280 \\
2.859 \\
8.570 \\
3.010\end{array}$ & $\begin{array}{l}503.0 \\
503.0 \\
101.0 \\
231.0 \\
120.0\end{array}$ & $\begin{array}{l}3: \\
1: \\
1:\end{array}$ & $\begin{array}{l}0 . \\
0 . \\
0 . \\
0 . \\
0 .\end{array}$ \\
\hline $\begin{array}{l}141 \\
142 \\
143 \\
144 \\
145\end{array}$ & $\begin{array}{l}2 . \\
2 . \\
2 . \\
2 .\end{array}$ & $\begin{array}{l}73 . \\
73 . \\
74 . \\
74 . \\
74 .\end{array}$ & $\begin{array}{l}4 . \\
5 . \\
1 . \\
2 . \\
3 .\end{array}$ & $\begin{array}{l}3 . \\
3 . \\
3 .\end{array}$ & $\begin{array}{l}5 . \\
5 . \\
2 . \\
2 .\end{array}$ & $\begin{array}{l}245 . \\
237 . \\
131 . \\
131 . \\
235 .\end{array}$ & $\begin{array}{l}71.190 \\
43.400 \\
24.872 \\
35.160 \\
57.730\end{array}$ & $\begin{array}{r}503.0 \\
503.0 \\
1001.0 \\
201.0 \\
503.0\end{array}$ & $\begin{array}{l}1 . \\
1: \\
1:\end{array}$ & $\begin{array}{l}0 . \\
0 . \\
0 . \\
0 . \\
0 .\end{array}$ \\
\hline $\begin{array}{l}146 \\
147 \\
148 \\
149 \\
150\end{array}$ & $\begin{array}{l}2 . \\
2 . \\
2 . \\
2 .\end{array}$ & $\begin{array}{l}74 . \\
74 . \\
74 . \\
75 . \\
75 .\end{array}$ & $\begin{array}{l}4 . \\
5 . \\
1 . \\
2 .\end{array}$ & $\begin{array}{l}3 . \\
3 . \\
3 .\end{array}$ & $\begin{array}{l}2 . \\
2 . \\
2 . \\
4 .\end{array}$ & $\begin{array}{r}251 . \\
90251 . \\
274 . \\
139 . \\
118 .\end{array}$ & $\begin{array}{r}148.443 \\
148.330 \\
50.290 \\
24.533 \\
5.180\end{array}$ & $\begin{array}{l}503.0 \\
503.0 \\
503.0 \\
627.5 \\
201.0\end{array}$ & $\begin{array}{l}1: . \\
1: \\
1:\end{array}$ & $\begin{array}{l}1 . \\
2 . \\
0 . \\
0 .\end{array}$ \\
\hline $\begin{array}{l}151 \\
152 \\
153 \\
154 \\
155\end{array}$ & $\begin{array}{l}2 . \\
2 . \\
2 . \\
2 . \\
2 .\end{array}$ & $\begin{array}{l}75 . \\
75 . \\
75 . \\
76 . \\
76 .\end{array}$ & $\begin{array}{l}3 . \\
4 . \\
5: \\
1 . \\
2 .\end{array}$ & $\begin{array}{l}3 . \\
3 . \\
3 . \\
3 .\end{array}$ & $\begin{array}{l}3 . \\
4 . \\
4 .\end{array}$ & $\begin{array}{l}232 . \\
265 . \\
312 . \\
137 . \\
131 .\end{array}$ & $\begin{array}{r}2.850 \\
9.020 \\
1.580 \\
37.995 \\
23.020\end{array}$ & $\begin{array}{r}503.0 \\
503.0 \\
120.0 \\
1010.0 \\
201.0\end{array}$ & $\begin{array}{l}1 . \\
1: \\
1:\end{array}$ & $\begin{array}{l}0 . \\
0 . \\
0 . \\
0 . \\
0 .\end{array}$ \\
\hline $\begin{array}{l}156 \\
157 \\
158 \\
159 \\
150\end{array}$ & $\begin{array}{l}2 . \\
2 . \\
2 . \\
2 .\end{array}$ & $\begin{array}{l}76 . \\
76 . \\
76 . \\
76 . \\
77 .\end{array}$ & $\begin{array}{l}3 . \\
4 . \\
5: \\
1 .\end{array}$ & $\begin{array}{l}3 . \\
3 . \\
3 . \\
3 .\end{array}$ & $\begin{array}{l}2 . \\
3 . \\
4 . \\
2 .\end{array}$ & $\begin{array}{r}290 . \\
272 . \\
311 . \\
00311 . \\
66 .\end{array}$ & $\begin{array}{l}21.290 \\
16.760 \\
14.470 \\
15.163 \\
30.573\end{array}$ & $\begin{array}{l}503.0 \\
503.0 \\
503.0 \\
503.0 \\
501.0\end{array}$ & $\begin{array}{l}1 . \\
1 . \\
1 .\end{array}$ & $\begin{array}{l}0 . \\
0 . \\
1 . \\
2 . \\
0 .\end{array}$ \\
\hline $\begin{array}{l}161 \\
162 \\
163 \\
166 \\
165\end{array}$ & $\begin{array}{l}2 . \\
2 . \\
2 . \\
2 . \\
2 .\end{array}$ & $\begin{array}{l}77 . \\
77 \\
77 \\
77 \\
77 .\end{array}$ & $\begin{array}{l}2 . \\
3 . \\
4 . \\
4 . \\
5 .\end{array}$ & $\begin{array}{l}3 . \\
3 . \\
3 . \\
3 .\end{array}$ & $\begin{array}{l}2 . \\
2 . \\
2 . \\
2 .\end{array}$ & $\begin{array}{r}133 . \\
238 . \\
258 . \\
90258 . \\
274 .\end{array}$ & $\begin{array}{r}13.500 \\
87.000 \\
208.075 \\
217.813 \\
44.603\end{array}$ & $\begin{array}{r}431.0 \\
503.0 \\
13078.0 \\
13078.0 \\
533.0\end{array}$ & $\begin{array}{l}1 . \\
1: \\
1:\end{array}$ & $\begin{array}{l}0 . \\
0 . \\
1 . \\
2 .\end{array}$ \\
\hline $\begin{array}{l}166 \\
167 \\
188 \\
169 \\
170\end{array}$ & $\begin{array}{l}2 . \\
2 . \\
2 . \\
2 .\end{array}$ & $\begin{array}{l}78 . \\
78 . \\
78 . \\
78 . \\
78 .\end{array}$ & $\begin{array}{l}1 . \\
2 . \\
3 . \\
4 . \\
5 .\end{array}$ & $\begin{array}{l}3 . \\
3 . \\
3 . \\
3 .\end{array}$ & $\begin{array}{l}2 . \\
2 . \\
2 . \\
2 .\end{array}$ & $\begin{array}{r}57 . \\
112 . \\
239 . \\
257 . \\
273 .\end{array}$ & $\begin{array}{r}34.378 \\
3.970 \\
118.510 \\
51.260 \\
94.580\end{array}$ & $\begin{array}{l}401.0 \\
401.0 \\
503.0 \\
503.0 \\
533.0\end{array}$ & $\begin{array}{l}1 . \\
1: \\
1 .\end{array}$ & $\begin{array}{l}0 . \\
0 . \\
0 . \\
0 . \\
0 .\end{array}$ \\
\hline $\begin{array}{l}171 \\
172 \\
173 \\
174 \\
175\end{array}$ & $\begin{array}{l}2 . \\
2 . \\
2 . \\
2 .\end{array}$ & $\begin{array}{l}81 . \\
81 . \\
81 . \\
81 . \\
81 .\end{array}$ & $\begin{array}{l}1 . \\
2 . \\
3 . \\
5 .\end{array}$ & $\begin{array}{l}3 . \\
3 . \\
3 . \\
3 .\end{array}$ & $\begin{array}{l}4 . \\
4 . \\
4 .\end{array}$ & $\begin{array}{l}59 . \\
145 . \\
236 . \\
235 . \\
275 .\end{array}$ & $\begin{array}{r}32.352 \\
91.910 \\
97.770 \\
173.600 \\
69.690\end{array}$ & $\begin{array}{r}1001.0 \\
401.0 \\
503.0 \\
503.0 \\
503.0\end{array}$ & $\begin{array}{l}1: \\
1: \\
1:\end{array}$ & $\begin{array}{l}0 . \\
0 . \\
0 . \\
0 . \\
0 .\end{array}$ \\
\hline $\begin{array}{l}176 \\
177 \\
178 \\
179 \\
180\end{array}$ & $\begin{array}{l}2 . \\
2: \\
2: \\
i\end{array}$ & $\begin{array}{l}82 . \\
82 . \\
52 . \\
32 . \\
32 .\end{array}$ & $\begin{array}{l}1 . \\
2 . \\
2 . \\
3 . \\
4 .\end{array}$ & $\begin{array}{l}3 . \\
3 . \\
3 . \\
3 .\end{array}$ & $\begin{array}{l}2 . \\
2 . \\
2 . \\
2 .\end{array}$ & $\begin{array}{r}50 . \\
138 . \\
00138 . \\
235 . \\
224 .\end{array}$ & $\begin{array}{l}11.307 \\
35.805 \\
33.990 \\
58.400 \\
31.080\end{array}$ & $\begin{array}{l}131.0 \\
201.0 \\
201.0 \\
503.0 \\
503.0\end{array}$ & $\begin{array}{l}1: \\
1:\end{array}$ & $\begin{array}{l}0 . \\
1: \\
0: \\
0 .\end{array}$ \\
\hline
\end{tabular}


IABLE A.2. (contd)

\begin{tabular}{|c|c|c|c|c|c|c|c|c|c|c|}
\hline Case & stype & $\underline{\text { Loc }}$ & Run & Rounds & NCMP & $\mathrm{ClO}$ & DU.MG/L & DILU & LEEACH & Rep \\
\hline 181 & 2. & 32. & 5. & 3. & 2. & 276. & 28.530 & 503.0 & 1. & $0:$ \\
\hline $\begin{array}{l}132 \\
183\end{array}$ & 2 & 33. & i: & 3. & 6. & 53. & 40.569 & 1001.0 & $\because$. & $\ddot{2}$ \\
\hline 184 & 2 & 93. & $\begin{array}{l}1 . \\
2 .\end{array}$ & 3. & s: & $\begin{array}{l}90353 . \\
136 .\end{array}$ & $\begin{array}{l}70.837 \\
36.720\end{array}$ & $\begin{array}{r}6275.0 \\
231.0\end{array}$ & $\because$ & 2 \\
\hline 185 & 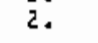 & 83. & 2. & 3. & 7 & 90135. & 70.210 & 601.0 & $1 \%$ & 2. \\
\hline 156 & 2. & 83. & 3. & 3. & s. & $2: 0$ & $77.18 \mathrm{~J}$ & 503.0 & 1. & 0. \\
\hline 187 & 2. & 33. & 4. & 3. & 3. & 230. & 69.550 & 505.0 & 1. & 0 \\
\hline $1 \mathrm{BB}$ & 2. & 83. & 5. & 3. & 5. & 277. & 31.303 & 503.0 & 1. & 0. \\
\hline 189 & 2. & 84. & 1. & 3. & 4. & $6 ?$. & 23.682 & 501.0 & 1 . & 0. \\
\hline 190 & 2. & 84. & 2. & 3. & 4. & 142 & 58.820 & 201.0 & 1. & 0. \\
\hline 171 & 2. & 94. & 3. & 3. & 4. & 237. & 117.060 & 503.0 & 1. & 0. \\
\hline 492 & 2. & 94. & 4. & 3. & 4. & 231. & 195.590 & 503.0 & 1 . & 0. \\
\hline 193 & 2. & 84. & 5. & 3. & 4 & 278. & 116.740 & 503.0 & $1 \cdot$ & 0. \\
\hline 179 & 2 & 35. & $2:$ & 3. & 4. & $\begin{array}{l}69 . \\
151 .\end{array}$ & $\begin{array}{l}47.937 \\
59.100\end{array}$ & $\begin{array}{r}2211.0 \\
201.0\end{array}$ & $\because$ & 0. \\
\hline 196 & 2. & B5. & 3. & 3. & 4. & 220 & 134.690 & 503.0 & 1. & 0. \\
\hline 197 & 2. & 85. & 4. & 3. & 5. & 229. & $\$ 5.233$ & 2515.0 & 1. & 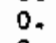 \\
\hline 198 & 2. & 85. & 5. & 3. & 4. & 279. & 32.560 & 503.0 & 1. & a. \\
\hline 199 & 2. & 36. & 1. & 3. & 4. & 63. & 13.982 & 201.0 & 1. & 0. \\
\hline 200 & 2. & 36. & 2. & 3. & 4. & 137. & 69.720 & 201.0 & 7. & 0. \\
\hline 201 & 2. & 86. & 3. & 3. & 4. & 219. & $135.64 J$ & 503.0 & 1. & $O_{0}$ \\
\hline 202 & 2. & 86. & 6. & 3. & 4. & $2 \geq 7$ & 131.813 & 533.0 & $\because$ & - \\
\hline 204 & 20 & 96. & 30 & 3. & 4 & 230. & 16.230 & 503.0 & 1. & 0. \\
\hline 205 & 2. & 91. & $\ddot{2}$ & 3. & 4. & 153. & $\begin{array}{l}17.0182 \\
34.483\end{array}$ & 401.0 & $\because$ & 0. \\
\hline 206 & 2. & 91. & 3. & 3. & 4. & 218. & 43.840 & 503.0 & 1. & D. \\
\hline 207 & 2. & 91. & 4. & 3. & 4. & 232. & 49.573 & 533.0 & 1. & 0. \\
\hline 208 & 2. & 91. & 5. & $3=$ & 4. & 231. & 27.370 & 503.0 & 1. & 0. \\
\hline 210 & 2. & 72. & 1. & 3. & 6. & 50. & 1.308 & 41.0 & 1. & o. \\
\hline 211 & 2. & 72 & 3. & 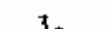 & 4. & 217 & 4867 & 503.0 & 1. & 0 \\
\hline 212 & 2. & 92. & 4. & 3. & 4. & 226. & 23.270 & 2595.0 & 1. & 0 \\
\hline 213 & 2. & 92. & 5. & 3. & 4. & 232. & 6.000 & 503.0 & 1. & 0. \\
\hline 214 & 2. & 93. & 1. & 3. & 4. & 45. & 0.034 & 2.5 & 1. & 0. \\
\hline 215 & 2. & 93. & 2. & 3. & 4. & 156. & 1.523 & 51.0 & 1. & 0. \\
\hline 216 & 2. & 93. & 3. & 3. & 4. & 221. & 2.050 & 505.0 & 1. & 0. \\
\hline 217 & 2. & 93. & 4 & 3. & 4. & 234. & 1.543 & 2515.0 & 1. & 0. \\
\hline 218 & 2. & 93. & 5. & 3. & 4. & 234. & 1.637 & 120.0 & 1. & o. \\
\hline 219 & 2. & 94. & 1. & 3. & 4. & $\$ 6$. & 0.007 & 1.0 & 1. & 0. \\
\hline 220 & 2. & 94. & 2. & 3. & 4. & 163. & 0.030 & 2.5 & 1. & 0. \\
\hline 221 & 2. & 94. & 3. & 3. & 4. & 228. & 3.030 & 1.0 & $\because$ & 0. \\
\hline 222 & 2. & 94. & 4. & 3. & $4=$ & 222. & $1.42 J$ & 503.0 & 1. & \\
\hline 223 & 2. & $94^{\circ}$ & 5. & 3. & 4. & 233. & 0.150 & $\$ 20.0$ & १. & 0. \\
\hline 225 & 2. & $90^{\circ}$ & 4. & 7 & $1:$ & $\begin{array}{l}137 . \\
256 .\end{array}$ & $\begin{array}{l}29.3550 \\
92.4880\end{array}$ & $\begin{array}{r}533.00 \\
2515.0\end{array}$ & 1. & 3. \\
\hline
\end{tabular}


TABLE A.2. (contd)

\begin{tabular}{|c|c|c|c|c|c|c|c|c|c|c|}
\hline Cose & Stype & $\angle O C$ & Run & Rounds & NCMP & cio & DU. $M S / L$ & OILU & LEEACH & Rep \\
\hline $\begin{array}{l}226 \\
227 \\
228 \\
229 \\
230\end{array}$ & $\begin{array}{l}3 . \\
3 . \\
3 . \\
3 .\end{array}$ & $\begin{array}{l}41 . \\
41 . \\
41 . \\
49 \\
49\end{array}$ & $\begin{array}{l}1: \\
1: \\
1:\end{array}$ & $\begin{array}{l}3: \\
1:\end{array}$ & $\begin{array}{l}i: \\
1: \\
1: \\
1:\end{array}$ & $\begin{array}{l}1: \\
2: \\
2: \\
3 .\end{array}$ & $\begin{array}{r}15829.590 \\
991.100 \\
234.900 \\
7780.480 \\
7564.750\end{array}$ & $\begin{array}{r}101625.0 \\
-1.0 \\
-1.0 \\
50833.0 \\
50803.0\end{array}$ & $\begin{array}{l}2 . \\
3 . \\
3 . \\
2 .\end{array}$ & $\begin{array}{l}0 . \\
0 . \\
0 . \\
0 . \\
0 .\end{array}$ \\
\hline $\begin{array}{l}231 \\
232 \\
233 \\
234 \\
235\end{array}$ & $\begin{array}{l}3 . \\
3 . \\
3 .\end{array}$ & $\begin{array}{l}41 . \\
41 . \\
41 . \\
42 .\end{array}$ & $\begin{array}{l}i: \\
2: \\
2 . \\
2 .\end{array}$ & i: & $\begin{array}{l}1: \\
i: \\
i:\end{array}$ & $\begin{array}{l}3 . \\
4 . \\
5: \\
5 .\end{array}$ & $\begin{array}{r}34.100 \\
1033.360 \\
392.000 \\
238.500 \\
3052.400\end{array}$ & $\begin{array}{r}-1.0 \\
50803.0 \\
-1.0 \\
-1.0 \\
50803.0\end{array}$ & $\begin{array}{l}3 . \\
2 . \\
3 . \\
3 .\end{array}$ & $\begin{array}{l}0 . \\
0 . \\
0 . \\
0 . \\
0 .\end{array}$ \\
\hline $\begin{array}{l}236 \\
237 \\
238 \\
239 \\
260\end{array}$ & $\begin{array}{l}3 . \\
3 . \\
3 . \\
3 .\end{array}$ & $\begin{array}{l}41 . \\
41 \% \\
41 . \\
41 . \\
41 .\end{array}$ & $\begin{array}{l}2 . \\
2 . \\
3 . \\
3 . \\
3 .\end{array}$ & $\begin{array}{l}1: \\
1: \\
1:\end{array}$ & $\begin{array}{l}1 . \\
1: \\
1: \\
1:\end{array}$ & $\begin{array}{l}6 . \\
6 . \\
7 . \\
7 .\end{array}$ & $\begin{array}{r}777.083 \\
32.900 \\
251.000 \\
2757.690 \\
186.35 .900\end{array}$ & $\begin{array}{r}101103.0 \\
-1.0 \\
-9.0 \\
101103.0 \\
101103.0\end{array}$ & $\begin{array}{l}2 . \\
3 . \\
3 . \\
2 .\end{array}$ & $\begin{array}{l}0 . \\
0 . \\
0 . \\
0 . \\
0 .\end{array}$ \\
\hline $\begin{array}{l}241 \\
242 \\
243 \\
244 \\
245\end{array}$ & $\begin{array}{l}3 . \\
3 . \\
3 . \\
3 .\end{array}$ & $\begin{array}{l}49 . \\
41 . \\
49 . \\
41 . \\
49 .\end{array}$ & $\begin{array}{l}3 . \\
3 . \\
3 . \\
4 . \\
4 .\end{array}$ & $\begin{array}{l}\vdots: \\
1: \\
1:\end{array}$ & $\begin{array}{l}1: \\
1: \\
1:\end{array}$ & $\begin{array}{l}8 . \\
9 . \\
9 . \\
10 .\end{array}$ & $\begin{array}{r}133.900 \\
5201.750 \\
159.200 \\
4608.580 \\
103.100\end{array}$ & $\begin{array}{r}-1.0 \\
101103.0 \\
-1.0 \\
101103.0 \\
-1.0\end{array}$ & $\begin{array}{l}3 . \\
2: \\
3 . \\
3 .\end{array}$ & $\begin{array}{l}0 . \\
0 . \\
0 . \\
1 . \\
0 .\end{array}$ \\
\hline $\begin{array}{l}266 \\
247 \\
248 \\
269 \\
250\end{array}$ & $\begin{array}{l}3 . \\
3 . \\
3 . \\
3 .\end{array}$ & $\begin{array}{l}41 . \\
41 . \\
41 . \\
41 . \\
49\end{array}$ & $\begin{array}{l}4 . \\
4: \\
4 . \\
4 .\end{array}$ & $\begin{array}{l}1: \\
1: \\
1:\end{array}$ & $\begin{array}{l}1: \\
1: \\
1:\end{array}$ & $\begin{array}{r}11 . \\
11 . \\
12 . \\
12 . \\
90010 .\end{array}$ & $\begin{array}{r}30.000 \\
5197.190 \\
285.380 \\
45.403 \\
4191.430\end{array}$ & $\begin{array}{r}-1.0 \\
101133.0 \\
302303.0 \\
-1.0 \\
101103.0\end{array}$ & $\begin{array}{l}3 . \\
2 . \\
3 \\
2:\end{array}$ & $\begin{array}{l}0 . \\
0 . \\
0 . \\
0 . \\
2 .\end{array}$ \\
\hline $\begin{array}{l}251 \\
252 \\
253 \\
254 \\
255\end{array}$ & $\begin{array}{l}3 . \\
3 . \\
3: \\
3 .\end{array}$ & $\begin{array}{l}41 . \\
41 . \\
41 . \\
41 . \\
41 .\end{array}$ & $\begin{array}{l}5 . \\
5: \\
5: \\
5 . \\
5 .\end{array}$ & $\begin{array}{l}1 . \\
1: \\
1:\end{array}$ & $\begin{array}{l}1: \\
1: \\
1: \\
1:\end{array}$ & $\begin{array}{l}13 . \\
13 . \\
94.1 \\
14 .\end{array}$ & $\begin{array}{c}558.000 \\
64619.078 \\
81994.266) \\
4973.920 \\
693.100\end{array}$ & $\begin{array}{r}-1.0 \\
302303.0 \\
302303.0 \\
302333.0 \\
-9.0\end{array}$ & $\begin{array}{l}3 . \\
2 . \\
2-5 \\
3 .\end{array}$ & $\begin{array}{l}0 . \\
0 . \\
0 . \\
0 . \\
0 .\end{array}$ \\
\hline $\begin{array}{l}256 \\
257 \\
.258\end{array}$ & $\begin{array}{l}3 . \\
3 .\end{array}$ & $\begin{array}{l}41 . \\
41 . \\
41 .\end{array}$ & $\begin{array}{l}5 . \\
5 . \\
5 .\end{array}$ & $\begin{array}{l}1 . \\
1 . \\
1 .\end{array}$ & $\begin{array}{l}1 . \\
1 .\end{array}$ & $\begin{array}{r}15 . \\
15 . \\
90015 .\end{array}$ & $\begin{array}{r}215.100 \\
30053.520 \\
32949.253\end{array}$ & $\begin{array}{r}-1.0 \\
302303.0 \\
126253.0\end{array}$ & $\begin{array}{l}3 . \\
2 . \\
2 .\end{array}$ & $\begin{array}{l}0 . \\
1 . \\
2 .\end{array}$ \\
\hline $\begin{array}{l}259 \\
260\end{array}$ & 4. & $\begin{array}{l}11 . \\
11 .\end{array}$ & $1:$ & 3. & 1. & $\begin{array}{l}5+20 \\
542 .\end{array}$ & $\begin{array}{r}753.920 \\
1028.730\end{array}$ & $\begin{array}{r}1053.0 \\
13078.0\end{array}$ & i: & 0. \\
\hline
\end{tabular}


TABLE A.2. (contd)

\begin{tabular}{|c|c|c|c|c|c|c|c|c|c|c|}
\hline Case & Stype & Loc & Run & Rounds & ACMP & CID & DU,MG/L. & DlLU & LEACH & Rep \\
\hline $\begin{array}{l}271 \\
272 \\
273 \\
274 \\
275\end{array}$ & $\begin{array}{l}4 . \\
4 . \\
4: \\
4 .\end{array}$ & $\begin{array}{l}11 . \\
11 . \\
11: \\
11 . \\
11 .\end{array}$ & $\begin{array}{l}4 . \\
4 . \\
5: \\
5 .\end{array}$ & $\begin{array}{l}3 . \\
3: \\
3 . \\
3 .\end{array}$ & $\begin{array}{l}1 . \\
1: \\
1: \\
1:\end{array}$ & $\begin{array}{r}534 . \\
00534 . \\
538 . \\
549 . \\
90523 .\end{array}$ & $\begin{array}{r}135.050 \\
78.920 \\
425.830 \\
187.510 \\
498.980\end{array}$ & $\begin{array}{r}25653.0 \\
25653.0 \\
3018.0 \\
533.0 \\
3018.0\end{array}$ & $\begin{array}{l}2 . \\
2 . \\
2: \\
2: \\
2 .\end{array}$ & $\begin{array}{l}1 . \\
1: \\
0 .\end{array}$ \\
\hline $\begin{array}{l}270 \\
277 \\
278 \\
279 \\
280\end{array}$ & $\begin{array}{l}4 . \\
4 . \\
4 . \\
4 .\end{array}$ & $\begin{array}{l}12 . \\
12 . \\
12 . \\
12 . \\
12 .\end{array}$ & $\begin{array}{l}1 . \\
1 . \\
1 . \\
1 .\end{array}$ & $\begin{array}{l}3 . \\
3 . \\
3 . \\
3 .\end{array}$ & $\begin{array}{l}1: \\
1: \\
1: \\
1 .\end{array}$ & $\begin{array}{l}537 . \\
537 . \\
543 . \\
563 . \\
531 .\end{array}$ & $\begin{array}{r}40.840 \\
14.980 \\
735.043 \\
242.123 \\
23.630\end{array}$ & $\begin{array}{r}533.0 \\
533.0 \\
10563.0 \\
5533.0 \\
503.0\end{array}$ & $\begin{array}{l}2: \\
1: \\
1: \\
2:\end{array}$ & $\begin{array}{l}0 . \\
0 . \\
0 . \\
0 .\end{array}$ \\
\hline $\begin{array}{l}231 \\
282 \\
283 \\
284 \\
235\end{array}$ & $\begin{array}{l}4 . \\
4 . \\
4 . \\
4 .\end{array}$ & $\begin{array}{l}12 . \\
12 . \\
12= \\
12 . \\
12 .\end{array}$ & $\begin{array}{l}2 . \\
2 . \\
3 . \\
3 .\end{array}$ & $\begin{array}{l}3 . \\
3 . \\
3 . \\
3 .\end{array}$ & $\begin{array}{l}1: \\
1: \\
1:\end{array}$ & $\begin{array}{l}559 . \\
534 . \\
558 . \\
570 . \\
527 .\end{array}$ & $\begin{array}{r}79.060 \\
27.993 \\
123.290 \\
31.390 \\
114.410\end{array}$ & $\begin{array}{r}5533.0 \\
3018.0 \\
5533.0 \\
533.0 \\
25653.0\end{array}$ & $\begin{array}{l}2 . \\
2 . \\
2 . \\
2 . \\
2 .\end{array}$ & $\begin{array}{l}0 . \\
0 . \\
0 . \\
0 . \\
0 .\end{array}$ \\
\hline $\begin{array}{l}286 \\
287 \\
238 \\
289 \\
290\end{array}$ & $\begin{array}{l}4 . \\
4 . \\
4 . \\
4 .\end{array}$ & $\begin{array}{l}12 . \\
12 . \\
12 . \\
13 . \\
13 .\end{array}$ & $\begin{array}{l}4 . \\
5 . \\
5 . \\
1 . \\
1 .\end{array}$ & $\begin{array}{l}3 . \\
3 . \\
3 . \\
3 .\end{array}$ & $\begin{array}{l}1: \\
1: \\
1:\end{array}$ & $\begin{array}{l}532 . \\
526 . \\
535 . \\
536 . \\
536 .\end{array}$ & $\begin{array}{r}357.760 \\
76.603 \\
53.403 \\
48.700 \\
392.063\end{array}$ & $\begin{array}{r}25353.0 \\
503.0 \\
503.0 \\
503.0 \\
10553.0\end{array}$ & $\begin{array}{l}2 . \\
2 . \\
2 . \\
2 .\end{array}$ & $\begin{array}{l}0 . \\
0 . \\
0 . \\
0 . \\
1 .\end{array}$ \\
\hline $\begin{array}{l}271 \\
292 \\
293 \\
294 \\
295\end{array}$ & $\begin{array}{l}4 . \\
4 . \\
4 . \\
4 .\end{array}$ & $\begin{array}{l}13 . \\
13 . \\
13 \\
13 \\
13 .\end{array}$ & $\begin{array}{l}1 . \\
1: \\
2: \\
2 .\end{array}$ & $\begin{array}{l}3 . \\
3 . \\
3 . \\
3 .\end{array}$ & $\begin{array}{l}1: \\
1: \\
1:\end{array}$ & $\begin{array}{r}544 . \\
564 . \\
90536 . \\
553 . \\
533 .\end{array}$ & $\begin{array}{r}50.530 \\
776.590 \\
47.550 \\
450.310 \\
45.630\end{array}$ & $\begin{array}{r}5533.0 \\
10563.0 \\
503.0 \\
10553.0 \\
533.0\end{array}$ & $\begin{array}{l}2 . \\
1: \\
2: \\
2:\end{array}$ & $\begin{array}{l}0 . \\
0 . \\
2 . \\
0 . \\
0 .\end{array}$ \\
\hline $\begin{array}{l}296 \\
297 \\
298 \\
299 \\
300\end{array}$ & $\begin{array}{l}4 . \\
40 \\
40 \\
4 .\end{array}$ & $\begin{array}{l}13 . \\
13 . \\
13 . \\
13 . \\
13 .\end{array}$ & $\begin{array}{l}2 . \\
3 . \\
3 . \\
3 .\end{array}$ & $\begin{array}{l}3 . \\
3 . \\
3 . \\
3 . \\
3 .\end{array}$ & $\begin{array}{l}1: \\
1: \\
1: \\
1:\end{array}$ & $\begin{array}{r}559 . \\
533 . \\
566 . \\
90533 . \\
90563 .\end{array}$ & $\begin{array}{l}38.510 \\
41.013 \\
59.430 \\
42.320 \\
52.150\end{array}$ & $\begin{array}{r}5533.0 \\
3018.0 \\
10553.0 \\
3018.0 \\
3018.0\end{array}$ & $\begin{array}{l}2 . \\
2: \\
2: \\
2 . \\
2 .\end{array}$ & $\begin{array}{l}0 . \\
1: \\
1 . \\
2 . \\
2 .\end{array}$ \\
\hline $\begin{array}{l}301 \\
302 \\
303 \\
304 \\
305\end{array}$ & $\begin{array}{l}4 . \\
4 . \\
4 . \\
5 .\end{array}$ & $\begin{array}{r}33 . \\
13 . \\
13 . \\
0 . \\
0 .\end{array}$ & $\begin{array}{l}4 . \\
4 . \\
5 . \\
5 .\end{array}$ & $\begin{array}{l}3 . \\
3 . \\
3 . \\
3 .\end{array}$ & $\begin{array}{l}1 . \\
1: \\
3 .\end{array}$ & $\begin{array}{r}524 . \\
530 . \\
531 . \\
54131 . \\
54279 .\end{array}$ & $\begin{array}{r}93.900 \\
4.620 \\
51.390 \\
1956.533 \\
1957.320\end{array}$ & $\begin{array}{r}13078.0 \\
503.0 \\
503.0 \\
25653.0 \\
256535.0\end{array}$ & $\begin{array}{l}2 . \\
2 . \\
2 . \\
5 . \\
5 .\end{array}$ & $\begin{array}{l}0 . \\
0 . \\
0 . \\
0 . \\
0 .\end{array}$ \\
\hline $\begin{array}{l}306 \\
307 \\
308 \\
309 \\
310\end{array}$ & $\begin{array}{l}5 . \\
5: \\
5: \\
5 .\end{array}$ & $\begin{array}{l}0 . \\
1: \\
1: \\
1:\end{array}$ & $\begin{array}{l}5 . \\
1: \\
1: \\
1:\end{array}$ & $\begin{array}{l}3 . \\
3 . \\
3 . \\
3 .\end{array}$ & $\begin{array}{l}9 . \\
2 . \\
2= \\
2 . \\
2 .\end{array}$ & $\begin{array}{l}522517 . \\
113330 . \\
113334 . \\
116134 . \\
116116 .\end{array}$ & $\begin{array}{r}2040.950 \\
655.640 \\
1154.650 \\
779.170 \\
1028.050\end{array}$ & $\begin{array}{l}25653.0 \\
50803.0 \\
50803.0 \\
50803.0 \\
50803.0\end{array}$ & $\begin{array}{l}5 . \\
5 . \\
5 . \\
5 . \\
5 .\end{array}$ & $\begin{array}{l}0 . \\
0 . \\
0 . \\
0 . \\
0 .\end{array}$ \\
\hline $\begin{array}{l}311 \\
312 \\
313 \\
316 \\
315\end{array}$ & $\begin{array}{l}5 . \\
5 . \\
5 . \\
5 . \\
5 .\end{array}$ & $\begin{array}{l}1: \\
1: \\
1:\end{array}$ & $\begin{array}{l}1 . \\
1: \\
2 . \\
2 . \\
2 .\end{array}$ & $\begin{array}{l}3 . \\
3 . \\
3 . \\
3 .\end{array}$ & $\begin{array}{l}2 . \\
2 . \\
2 . \\
2 .\end{array}$ & $\begin{array}{l}116229 . \\
116214 . \\
211311 . \\
211315 . \\
216134 .\end{array}$ & $\begin{array}{l}1199.490 \\
1151.490 \\
1957.590 \\
1930.010 \\
1990.870\end{array}$ & $\begin{array}{l}50803.0 \\
50803.0 \\
25653.0 \\
50853.0 \\
50803.0\end{array}$ & $\begin{array}{l}5 . \\
5: \\
5 . \\
5 .\end{array}$ & $\begin{array}{l}0 . \\
0 . \\
0 . \\
0 . \\
0 .\end{array}$ \\
\hline
\end{tabular}


TABLE A.2. (contd)

\begin{tabular}{|c|c|c|c|c|c|c|c|c|c|c|}
\hline Case & Stype & $\underline{\text { Loc }}$ & Run. & Rounds & NCMP & CID & DUU.MG/L & DILU & $\underline{\text { LEACH }}$ & Rep \\
\hline 316 & 5. & 1. & 2. & 3. & 2. & 216110. & $2124.940^{-}$ & 50803.0 & 5. & 0. \\
\hline $31 ?$ & 5. & 1. & 2. & 3. & 2. & 216212 . & 274.380 & 553.0 & 5. & 1. \\
\hline 313 & 5. & 1. & 2 & 3. & 2. & 216212 . & 1852.873 & 50893.0 & 5. & 0. \\
\hline $\begin{array}{l}317 \\
320\end{array}$ & 5. & 1 . & 3. & 3 & 2. & $\begin{array}{l}216215 . \\
121832 .\end{array}$ & $\begin{array}{l}3637.083 \\
4532.040\end{array}$ & $\begin{array}{l}25653.0 \\
25653.0\end{array}$ & $\begin{array}{l}5 . \\
5 .\end{array}$ & 0. \\
\hline 321 & 5. & 1. & 3. & 3. & 4. & 141119 & 3732.383 & 26553.0 & 5. & 0. \\
\hline 322 & 5. & 1. & 4. & 7 & 4. & 46335. & 2032.470 & 2553.0 & 5. & 0. \\
\hline 323 & 5. & 1. & 4. & 7. & 4. & 462613. & 1523.200 & 25653.0 & 5. & 1. \\
\hline $3 \geq 4$ & 5. & $\because$ & 4- & 7. & 4. & & 1971.690 & 25653.0 & 5. & 2. \\
\hline 325 & 5. & 2. & 2. & 3. & 1. & 213215 & 734.920 & 50333.0 & 5. & 0. \\
\hline $\begin{array}{l}326 \\
327\end{array}$ & 5. & $\begin{array}{l}2 . \\
2 .\end{array}$ & 3. & 3. & 2: & $\begin{array}{l}7216212 . \\
1611915 .\end{array}$ & $\begin{array}{r}287.440 \\
3354.450\end{array}$ & $\begin{array}{r}5533.0 \\
13078.0\end{array}$ & $\begin{array}{l}5 . \\
5 .\end{array}$ & 2. \\
\hline 328 & 5. & 2. & 4. & 7. & 6 & 42513. & 2449.860 & 25653.0 & 5. & 0. \\
\hline 329 & 5. & 2. & 4. & $?$ & 4. & 46335. & 1745.170 & 25653.0 & 5. & 0. \\
\hline & & & & & & 452154. & 959.530 & 70503.0 & & \\
\hline $\begin{array}{l}331 \\
332\end{array}$ & 5. & 2. & 4: & 7 & $\because:$ & $\begin{array}{r}452154 . \\
7452154 .\end{array}$ & $\begin{array}{l}2473.290 \\
1224.230\end{array}$ & $\begin{array}{l}10563.0 \\
13078.0\end{array}$ & 5. & 0. \\
\hline 333 & 5 & 2. & 5. & $12=$ & $\because$ & $\begin{array}{r}7452154 . \\
253322 .\end{array}$ & $\begin{array}{l}1224.230 \\
6218.800\end{array}$ & $\begin{array}{l}13078.0 \\
25653.0\end{array}$ & $\begin{array}{l}5 . \\
8 .\end{array}$ & 2. \\
\hline 334 & 5. & 3. & $\because$ & 3. & 2. & 121337 & 732.110 & $50 B 05.0$ & 5. & 0. \\
\hline 335 & 5. & 3. & 1. & 3. & 2 & 121313. & 809.950 & 50803.0 & 5. & 0. \\
\hline 336 & 5. & 3. & 1. & 3. & 2. & 122331. & 1137.350 & 50803.0 & s. & 0. \\
\hline 337 & 5. & 3. & 1. & 3. & 2. & 123100. & 1150.380 & 50373.0 & 5. & 0 . \\
\hline 333 & 5. & 3. & 1. & 3. & 2. & 126237. & 914.100 & 50803.0 & 5. & 0. \\
\hline 339 & 5. & 3. & 1. & 3. & 2. & 124239. & 1141.900 & 50803.0 & 5. & 0. \\
\hline 340 & 5. & 3. & s. & 12. & 4. & 253153. & 3913.110 & 25653.0 & 3. & 0. \\
\hline 341 & 5. & 3. & 5. & 12. & 6 & 254121. & 3117.320 & 50803.0 & B. & 0. \\
\hline 342 & 5. & 40 & 5. & 15. & 4 & 53321. & 253.570 & 5533.0 & 5 & 0. \\
\hline $\begin{array}{l}343 \\
344\end{array}$ & $5:$ & $4:$ & 50 & 15. & 4. & 54112. & $\begin{array}{l}273.443 \\
275.880\end{array}$ & $\begin{array}{l}5533 \times 0 \\
5533 \times 0\end{array}$ & 5. & o. \\
\hline 345 & 6. & 81. & $\frac{2}{2}$ & 6. & i. & 24626 & 66052.906 & 304606.0 & 3. & a. \\
\hline 346 & 6. & 81. & 2. & 6. & 1. & 2. & 72325.930 & 322423.0 & 1. & 0. \\
\hline 347 & 6. & 81. & 3. & 3. & 1. & 3. & 91923.094 & 302303.0 & 1. & 0. \\
\hline 348 & 6. & B1. & 3. & 3. & 1. & 233. & 15501.520 & 50803.0 & $\because$ & 0. \\
\hline 349 & 6. & 81. & 4. & 3. & 1. & 4.1 & 20931.477 & 604505.0 & $\because$ & 0. \\
\hline 350 & 6. & 81. & 5. & 3. & 10 & 3. & 52139.801 & 606613.0 & 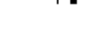 & 1. \\
\hline $\begin{array}{l}351 \\
352\end{array}$ & 6. & 81. & 5. & 3. & 1. & 90335. & 73121.727 & 606618.0 & 1. & 2. \\
\hline $\begin{array}{l}352 \\
353\end{array}$ & 6. & 84. & $4 \cdot$ & 3. & 1. & 1 . & 35485.680 & 126253.0 & $\because \cdot$ & 0. \\
\hline 354 & 6. & $91:$ & 5 & 3. & $\because$. & 1. & 52615.840 & 302303.0 & T* & 0. \\
\hline 355 & 6. & 92. & 4. & 3 & 1. & i: & $\begin{array}{r}8730.210 \\
9524.910\end{array}$ & $\begin{array}{l}302333.0 \\
101103.0\end{array}$ & 1. & 0. \\
\hline 356 & 6. & 92. & 5. & 3. & i. & 2. & 13250.670 & 101133.0 & 1. & 0. \\
\hline
\end{tabular}




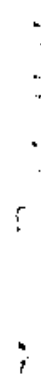

I

$r$ 


\section{APPENDIX B}

LISTING OF STANDARD SOLUTION AND YIELD STANDARD RESULTS 
TABLE B.1. Standard Solution Sample Results

\begin{tabular}{|c|c|c|c|}
\hline $\begin{array}{c}\text { Urani um } \\
\text { Standard } \\
\mathrm{g} / \mathrm{L}\end{array}$ & $\begin{array}{c}\text { Uranium } \\
\text { Recovered } \\
\mathrm{g} / \mathrm{L}\end{array}$ & $\begin{array}{c}\text { Percent } \\
\text { Recovered }\end{array}$ & $\begin{array}{r}\text { Average } \\
\text { Percent } \\
\text { Recovered }\end{array}$ \\
\hline 0.0010 & $\begin{array}{l}0.00093 \\
0.00102 \\
0.001105 \\
0.000955 \\
0.00102 \\
0.00097 \\
0.00097 \\
0.00101 \\
0.001150\end{array}$ & $\begin{array}{r}93.0 \\
102.0 \\
110.5 \\
95.5 \\
102.0 \\
97.0 \\
97.0 \\
101.0 \\
115.0\end{array}$ & $101.4+7$ \\
\hline 0.10185 & $\begin{array}{l}0.09739 \\
0.10461 \\
0.10649 \\
0.1065 \\
0.090818 \\
0.097582 \\
0.088434 \\
0.096982 \\
0.09695 \\
0.09449 \\
0.09663 \\
0.10407 \\
0.10443 \\
0.1008 \\
0.10679\end{array}$ & $\begin{array}{r}95.6 \\
102.7 \\
104.6 \\
104.6 \\
89.2 \\
95.8 \\
86.8 \\
95.2 \\
95.2 \\
92.8 \\
94.9 \\
102.2 \\
102.5 \\
99.0 \\
104.9\end{array}$ & $97.7 \pm 5.7$ \\
\hline 1.0185 & $\begin{array}{l}1.0387 \\
0.97389 \\
1.03137 \\
1.00355 \\
1.06345 \\
0.9171 \\
1.0125 \\
0.9585 \\
1.032 \\
0.90966\end{array}$ & $\begin{array}{r}102.0 \\
95.6 \\
101.3 \\
98.5 \\
104.9 \\
90.0 \\
99.4 \\
94.1 \\
101.3 \\
89.3\end{array}$ & \\
\hline
\end{tabular}


TABLE B.2. Coupon Yield Standard Sample Results

\begin{tabular}{|c|c|c|c|c|}
\hline $\begin{array}{l}\text { Sample } \\
\text { DU0, g }\end{array}$ & $\begin{array}{l}\text { Sample } \\
\text { J, g/L }\end{array}$ & $\begin{array}{c}\text { Uranium } \\
\text { Recovered } \\
\mathrm{g} / \mathrm{L}\end{array}$ & $\begin{array}{c}\text { Average } \\
\text { Percent } \\
\text { Recovered }\end{array}$ & $\begin{array}{c}\text { Average } \\
\text { Percent } \\
\text { Recovered }\end{array}$ \\
\hline 0.0107 & 0.00937 & $\begin{array}{l}0.00927 \\
0.01354 \\
0.00875 \\
0.008719 \\
0.011147 \\
0.009246 \\
0.00955\end{array}$ & $\begin{array}{l}98.9 \\
145.0(1) \\
93.4 \\
93.1 \\
119.0 \\
98.7 \\
101.9\end{array}$ & $100.8 \pm 9.5$ \\
\hline 0.1002 & 0.0877 & $\begin{array}{l}0.08597 \\
0.08625 \\
0.317898 \\
0.082509 \\
0.036432 \\
0.08453 \\
0.08082 \\
0.10041 \\
0.1036 \\
0.0987\end{array}$ & $\begin{array}{l}98.0 \\
98.3 \\
362.5^{(1)} \\
94.1 \\
41.5(2) \\
96.4 \\
92.2 \\
114.5 \\
118.1 \\
112.5\end{array}$ & $103.0 \pm 10.3$ \\
\hline 2.0 & 1.7514 & $\begin{array}{l}2.10098 \\
1.4874 \\
1.6208 \\
1.7150 \\
1.3786\end{array}$ & $\begin{array}{l}112.5 \\
120.0 \\
84.9 \\
92.5 \\
97.9 \\
78.7\end{array}$ & $94.8 \pm 15.9$ \\
\hline
\end{tabular}

\footnotetext{
(1) Excluded from average because result is anomalously high.

(2) Excluded from average because result is anomalously $10 \mathrm{w}$.
} 
TABLE B.3. Filter Yield Standard Sample Recovery

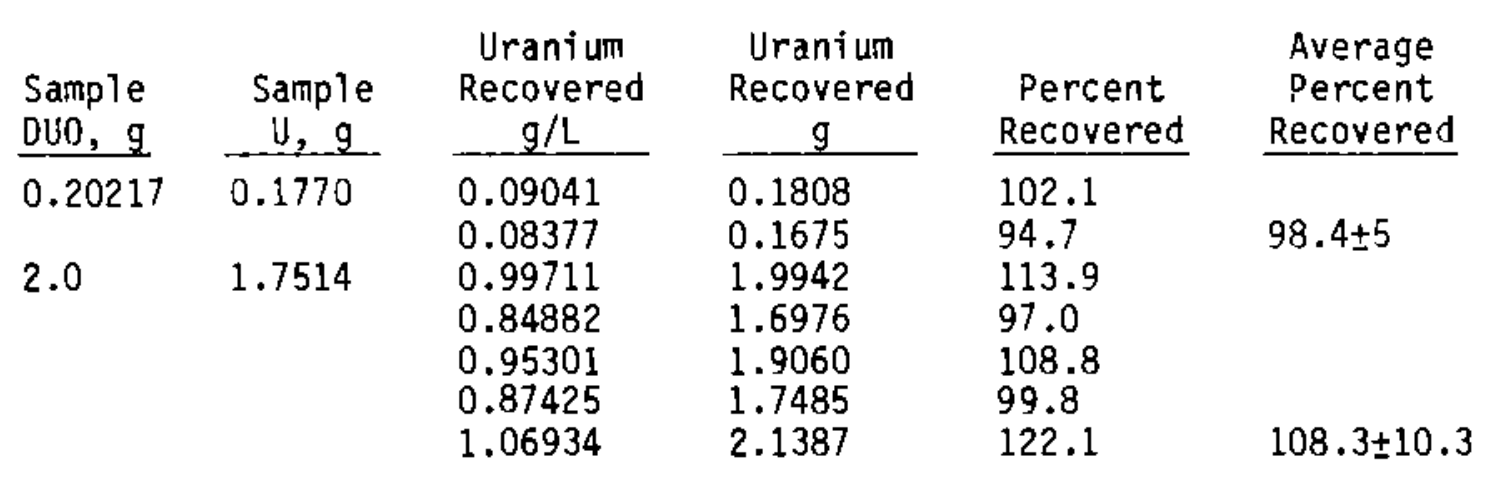


TABLE B.4. Soil Yield Standard Sample Results

\begin{tabular}{|c|c|c|c|c|c|}
\hline $\begin{array}{l}\text { Sample } \\
\text { DUD, g }\end{array}$ & $\begin{array}{c}\text { Sample } \\
U, g\end{array}$ & $\begin{array}{c}\text { Uranium } \\
\text { Recovered } \\
\mathrm{g} / \mathrm{L} \\
\end{array}$ & $\begin{array}{c}\text { Uranium } \\
\text { Recovered } \\
\mathrm{g} \\
\end{array}$ & $\begin{array}{c}\text { Percent } \\
\text { Recovered }\end{array}$ & $\begin{array}{c}\text { Average } \\
\text { Percent } \\
\text { Recovered }\end{array}$ \\
\hline $\begin{array}{l}0.1020 \\
2.0\end{array}$ & $\begin{array}{l}0.08932 \\
1.7514\end{array}$ & $\begin{array}{l}0.03828 \\
0.74325 \\
0.72643 \\
0.82317 \\
0.80294 \\
0.74070 \\
0.77192\end{array}$ & $\begin{array}{l}0.0766 \\
1.4865 \\
1.4529 \\
1.6463 \\
1.6059 \\
1.4814 \\
1.5438\end{array}$ & $\begin{array}{l}85.7 \\
84.9 \\
83.0 \\
94.0 \\
91.7 \\
84.6\end{array}$ & $87.7+4.4$ \\
\hline
\end{tabular}




\section{DISTRIBUTION}

No. of

Copies

OFFSITE

10 Commander Combat Systems Test Activity STECS-AA-A Ken Ruff Aberdeen Proving

Ground, Maryland 21005-5054

30 DOE Technical Information Center
No. of

Copies

ONSITE

34 Pacific Northwest Laboratory

D. W. Dragnich

J. A. Glissmeyer (15)

R. K. Hadlock

J. W. Johnston

N. S. Laulainen

I. Mishima

S. L. Sutter (6)

P. C. Hays

Publishing Coordination (2)

Technical Information (5) 


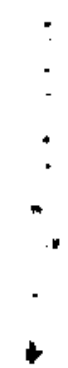

